\title{
Historical records of coastal eutrophication-induced hypoxia
}

\author{
A. J. Gooday ${ }^{1}$, F. Jorissen ${ }^{2}$, L. A. Levin ${ }^{3}$, J. J. Middelburg ${ }^{4,5}$, S. W. A. Naqvi ${ }^{6}$, N. N. Rabalais ${ }^{7}$, M. Scranton ${ }^{8}$, and \\ J. Zhang ${ }^{9}$ \\ ${ }^{1}$ National Oceanography Centre, Southampton, SO14 3ZH, UK \\ ${ }^{2}$ Laboratory of Recent and Fossil Bio-Indicators (UPRES EA 2644 BIAF), 2 Boulevard Lavoisier, 49045 Angers Cedex, \\ France, and LEBIM, Ile d'Yeu, France \\ ${ }^{3}$ Integrative Oceanography Division, Scripps Institution of Oceanography, 9500 Gilman Drive, La Jolla, CA 92093-0218, \\ USA \\ ${ }^{4}$ NIOO-KNAW, Centre for Estuarine and Marine Ecology, P.O. Box 140, 4400 AC Yerseke, The Netherlands \\ ${ }^{5}$ Faculty of Geosciences, Utrecht University, P.O. Box 80021, 3508 TA Utrecht, The Netherlands \\ ${ }^{6}$ National Institute of Oceanography, Dona Paula, Goa 403 004, India \\ ${ }^{7}$ Louisiana Universities Marine Consortium, Chauvin, Louisiana 70344, USA \\ ${ }^{8}$ The School of Marine and Atmospheric Sciences (SoMAS), Stony Brook University, Stony Brook, NY 11794-5000, USA \\ ${ }^{9}$ State Key Laboratory of Estuarine and Coastal Research, East China Normal University, 3663 Zhongshan Road North, Putuo \\ District, Shanghai 200062, China
}

Received: 23 December 2008 - Published in Biogeosciences Discuss.: 27 February 2009

Revised: 21 June 2009 - Accepted: 7 July 2009 - Published: 21 August 2009

\begin{abstract}
Under certain conditions, sediment cores from coastal settings subject to hypoxia can yield records of environmental changes over time scales ranging from decades to millennia, sometimes with a resolution of as little as a few years. A variety of biological and geochemical indicators (proxies) derived from such cores have been used to reconstruct the development of eutrophication and hypoxic conditions over time. Those based on (1) the preserved remains of benthic organisms (mainly foraminiferans and ostracods), (2) sedimentary features (e.g. laminations) and (3) sediment chemistry and mineralogy (e.g. presence of sulphides and redox-sensitive trace elements) reflect conditions at or close to the seafloor. Those based on (4) the preserved remains of planktonic organisms (mainly diatoms and dinoflagellates), (5) pigments and lipid biomarkers derived from prokaryotes and eukaryotes and (6) organic $\mathrm{C}, \mathrm{N}$ and their stable isotope ratios reflect conditions in the water column. However, the interpretation of these indicators is not straightforward. A central difficulty concerns the fact that hypoxia is strongly correlated with, and often induced by, organic enrichment caused by eutrophication, making it difficult to separate the effects of these phenomena in sediment records. The problem is compounded by the enhanced preservation in anoxic and hypoxic sediments of organic microfossils and biomarkers indicating eutrophication. The use of hypoxia-
\end{abstract}

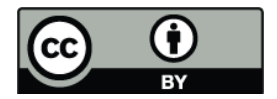

Correspondence to: A. J. Gooday (ang@noc.soton.ac.uk) specific proxies, such as the trace metals molybdenum and rhenium and the bacterial biomarker isorenieratene, together with multi-proxy approaches, may provide a way forward. All proxies of bottom-water hypoxia are basically qualitative; their quantification presents a major challenge to which there is currently no satisfactory solution. Finally, it is important to separate the effects of natural ecosystem variability from anthropogenic effects. Despite these problems, in the absence of historical data for dissolved oxygen concentrations, the analysis of sediment cores can provide plausible reconstructions of the temporal development of humaninduced hypoxia, and associated eutrophication, in vulnerable coastal environments.

\section{Introduction}

Eutrophication - nutrient enrichment leading to elevated production of particulate organic matter and in some cases hypoxia (Gray et al., 2002) - is one of the profound impacts inflicted on coastal ecosystems by human activities. These impacts began thousands of years ago (Jackson et al., 2001), but have increased in frequency and intensity since the middle of the 20th Century. Because marine eutrophication has only been acknowledged seriously since the mid-1980s (Nixon, 1995; Boesch, 2002), few long time-series environmental datasets are available from marine coastal settings (Clarke et al., 2003, 2006). Datasets extending back several decades

Published by Copernicus Publications on behalf of the European Geosciences Union. 
(e.g. Justić et al., 1987; Justić, 1991; Conley et al., 2007) or longer (Conley et al., 2009), and comparisons of historical and modern surface sediment samples (Alve and Murray, 1995; Rabalais et al., 1996, 2007; Thomas et al., 2000; McGann et al., 2003; Tsujimoto et al., 2006a; Nikulina et al., 2008), provide key information about natural, climateinduced variability and human influences that is necessary for the sustainable management of coastal habitats (Jackson, 2007). Historical records, e.g. dates of agricultural settlement and fisheries records, can also be useful. Such information is usually too limited, however, to provide a complete picture of past events. The analysis of proxy records preserved in sediments often provides the only way to reconstruct environmental change in areas impacted by eutrophication and hypoxia and to establish pre-impact baselines (Jackson et al., 2001; Alve, 2006). Because humans are changing coastal environments everywhere, these indicators may also provide our only glimpse of past, natural conditions and their inherent variability.

Certain conditions are necessary for the preservation and recovery of sediment records of coastal hypoxia. In addition to the availability of datable sediment cores, requirements include a relatively sheltered, low-energy setting that permits the deposition of fine-grained sediments, a sedimentation rate that is sufficient to allow for the resolution of the events of interest, and limited bioturbation and taphonomic processes that do not destroy the record (Murray and Alve, 2002; Clarke et al., 2006). These conditions can be found in estuaries, on continental shelves off the mouths of major rivers, in fjords, and areas where tidal disturbances are minimal. The time periods investigated range from decades to $>2000$ years, although the most intense human impacts generally occurred during the 20th Century. Where sedimentation rates are high, temporal resolution may be as little as a few years, at least for the 20th Century (Turner and Rabalais, 1994; Cronin and Vann, 2003). Studies of hypoxia in the sediment record began in the 1980s (e.g. Brush, 1984; Tyson and Pearson, 1991) but significant numbers of publications only began to appear in the 1990s and have increased substantially since 2000 . They have tended to concentrate in certain areas, notably the Louisiana continental shelf, Chesapeake Bay, Norwegian fjords and the Baltic Sea (Fig. 1).

A variety of hypoxia and eutrophication proxies, most of them biological or geochemical in nature, have been applied to sediment records. In this review, we are concerned mainly with records that span time scales during which human influences on coastal environments have left an obvious mark. These historical records can be regarded as a facet of palaeoceanography. Indeed, many of the proxies were originally developed to reconstruct palaeoenvironments in Cenozoic oceans (Fischer et al., 1999; Hillaire-Marcel and Vernal, 2007). Where appropriate, we cite some of this geological literature, for example, that relating to the intensively studied Mediterranean sapropels (Jorissen, 1999b; Jorissen et al., 2007). In addition to human influences, natural environmen- tal oscillations leave their imprint in sediment cores. A central issue when considering sediment records of coastal hypoxia is the close relationship between hypoxia (the degree of oxygenation) and eutrophication (which leads to an enhanced organic input to the seafloor). These two parameters are usually strongly correlated, and it is often not obvious which of them causes the changes observed in the sediment record. For example, foraminiferal species considered to be low-oxygen indicators are also associated with organic enrichment in the absence of bottom-water hypoxia, suggesting that they respond to changes in productivity rather than oxygenation (Jorissen et al., 2007). Another problem is that the preservation of organic matter and biomarkers is enhanced in hypoxic and anoxic settings (Hedges and Keil, 1995), partly through the reduction of animal activities (Cowie and Levin, 2009), making it difficult or impossible to distinguish hypoxia from enhanced carbon delivery resulting from eutrophication.

In addition to natural and anthropogenic eutrophication, hydrographic factors often help to intensify and maintain bottom-water hypoxia. Such factors include the isolation of deeper water masses by stratification of the water column or geographical confinement, and the advection of low-oxygen water from other sources (see Levin et al., 2009). In parts of the Baltic Sea, hypoxia during the Holocene and the modern era has been closely linked to water-column stratification caused by climate-related fluctuations in river runoff and saltwater inflows, although eutrophication has also been an important driver, particularly during the last 50 years (Laine et al., 2007; Zillén et al., 2008).

The deteriorating state of many near-shore habitats makes the study of hypoxia an urgent task. SCOR Working Group 128 aimed to synthesize the state of the science for the following aspects of coastal hypoxia: (1) its prevalence and spatio-temporal variability, (2) natural and human causes, (3) its effects on biogeochemistry and ecology, and (4) the resistance, resilience and recovery of ecosystems. Historical records preserved in sediment cores reveal information that is relevant to all of these goals. Unravelling the ecological history of vulnerable coastal environments is crucial for their management and for setting restoration and remediation targets. To paraphrase Johnson (2007), palaeoecological studies provide baselines for forecasting the consequences of environmental change, the best way to assess ecological responses to climate change, and a basis for studying events and processes for which there is no modern analogue. This review addresses biological, chemical and sedimentary indicators (proxies) that relate to either bottom-water hypoxia or eutrophication, or to a combination of these two phenomena. With the objectives of WG128 in mind, our goals are (1) to identify proxies that reveal the deterioration and recovery of ecosystems over time, (2) explore the effects of environmental change on ecosystems, (3) identify ways to distinguish natural from anthropogenic influences, and (4) suggest potentially useful new proxies and gaps in our knowledge. First, 


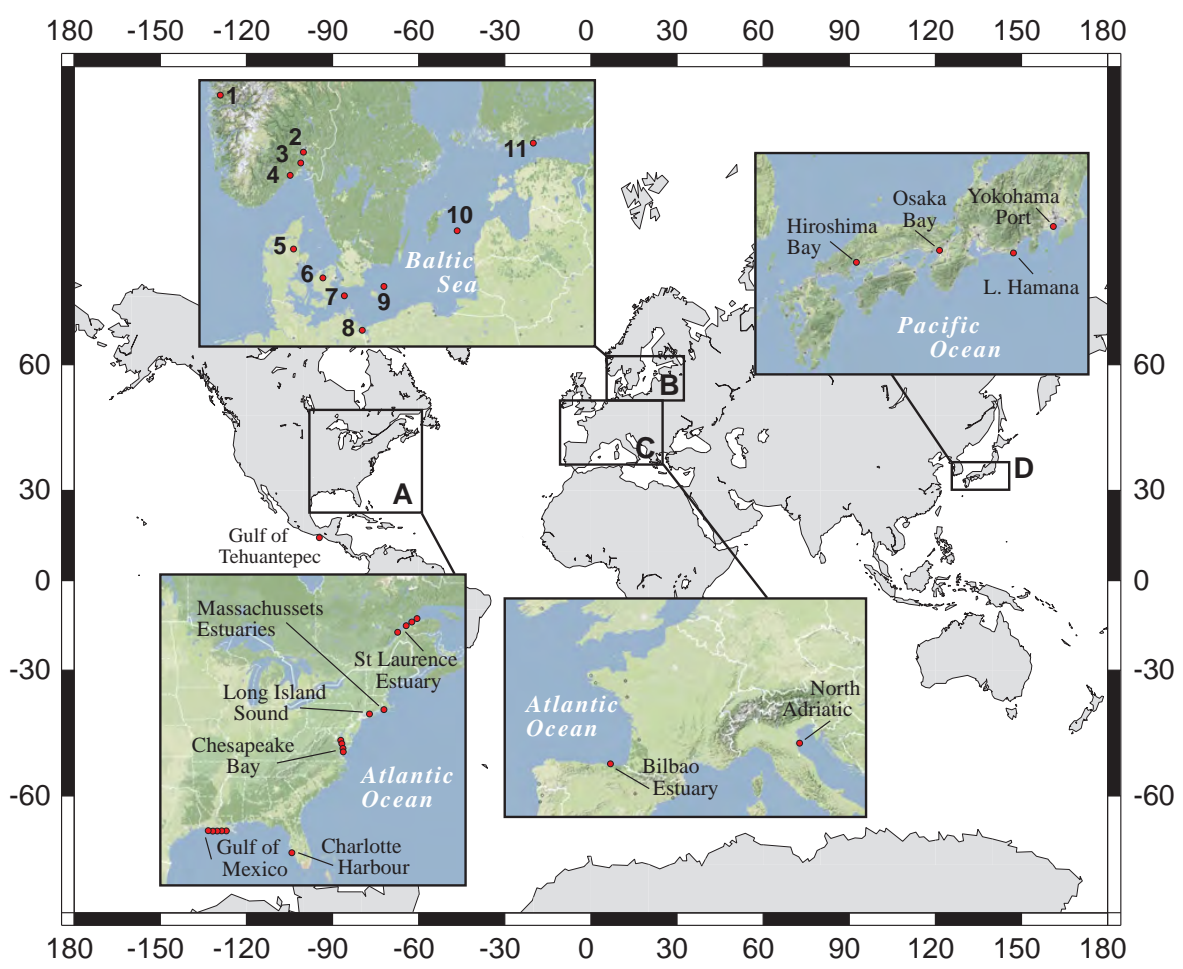

Fig. 1. The location of sites where studies of historical records have been conducted. The sites correspond to those listed in Table 1 . In the upper left panel: 1 = Kyllaren Fjord; 2 = Oslofjord; 3 = Drammensfjord; 4 = Frierfjord; 5 = Mariager Fjord; $6=$ Roskilde Fjord; $7=$ Arkona Basin; 8 = Oder Estuary; 9 = Bornholm Basin; 10 = Gotland Basin; 11 = Laajalahti Bay.

we review proxies for hypoxia and eutrophication based on benthic organisms and diagenetic processes (Sect. 3). Watercolumn derived proxies are presented in Sect. 4. Following the discussion (Sect. 5), we summarize our findings and identify new avenues of research. Table 1 provides an overview of the approaches used to study historical records at different localities (shown in Fig. 1). Table 2 summarises the various faunal, mineralogical and chemical proxies employed in these studies.

\section{Terminology}

We apply the term "proxy" in a broad sense to include qualitative as well as quantitative indicators.

Geologists and biologists use different terminologies to describe degrees of oxygen depletion and the various resulting biofacies (Tyson and Pearson, 1991; Jorissen et al., 2007). Geologists distinguish between oxic, suboxic, anoxic and euxinic (sulphide bearing) environments and biologists between oxic, hypoxic and anoxic environments; the term "exaerobic" was introduced for a biofacies characterised by laminated sediments combined with an accumulation of shelly fossils, reflecting short-term colonization of the seafloor by opportunistic species (Savrda and Bottjer, 1991)

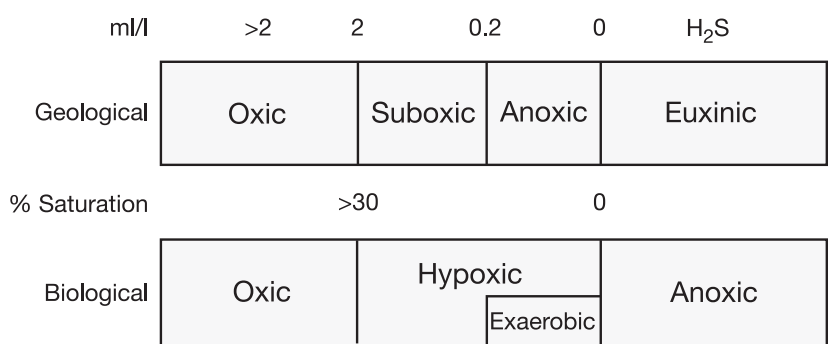

Fig. 2. Terminology used by geologists and biologists to describe oxygen depletion.

(Fig. 2). Some geochemical proxies distinguish between environments with and without hydrogen sulphide in the bottom waters.

Definitions of hypoxia are different in coastal and deep water settings. Whereas bathyal oxygen minimum zones are conventionally defined by oxygen concentrations of $<0.5 \mathrm{ml} \mathrm{L}^{-1}(\sim 22 \mu \mathrm{M})$, the upper limit of coastal hypoxia placed much higher, usually at $1.47 \mathrm{ml} \mathrm{L}^{-1}(\sim 65 \mu \mathrm{M})$. Although some animals may exhibit avoidance reactions, or even die, at these higher concentrations (Levin et al., 2009), most of the geochemical and faunal indicators of hypoxia become apparent only at much lower levels. 
Table 1. Studies using faunal and chemical indicators to trace human impacts in coastal environments. Lamin $=$ Laminations; Glauc = Glauconite; TrM = Trace metals; $\mathrm{BSi}=$ Biogenic silica; $\mathrm{TC}=$ total carbon; $\mathrm{TN}=$ total nitrogen. In area column $\mathrm{B}=\mathrm{Baltic} ; \mathrm{D}=\mathrm{Denmark}$; F = Finland; N = Norway; $\mathrm{S}=$ Spain; Fla = Florida; Mx = Mexico. See Brush (2001), Cronin and Vann (2003), Kemp et al. (2000) and Rabalais et al. (2007) for reviews of Chesapeake Bay and Gulf of Mexico records.

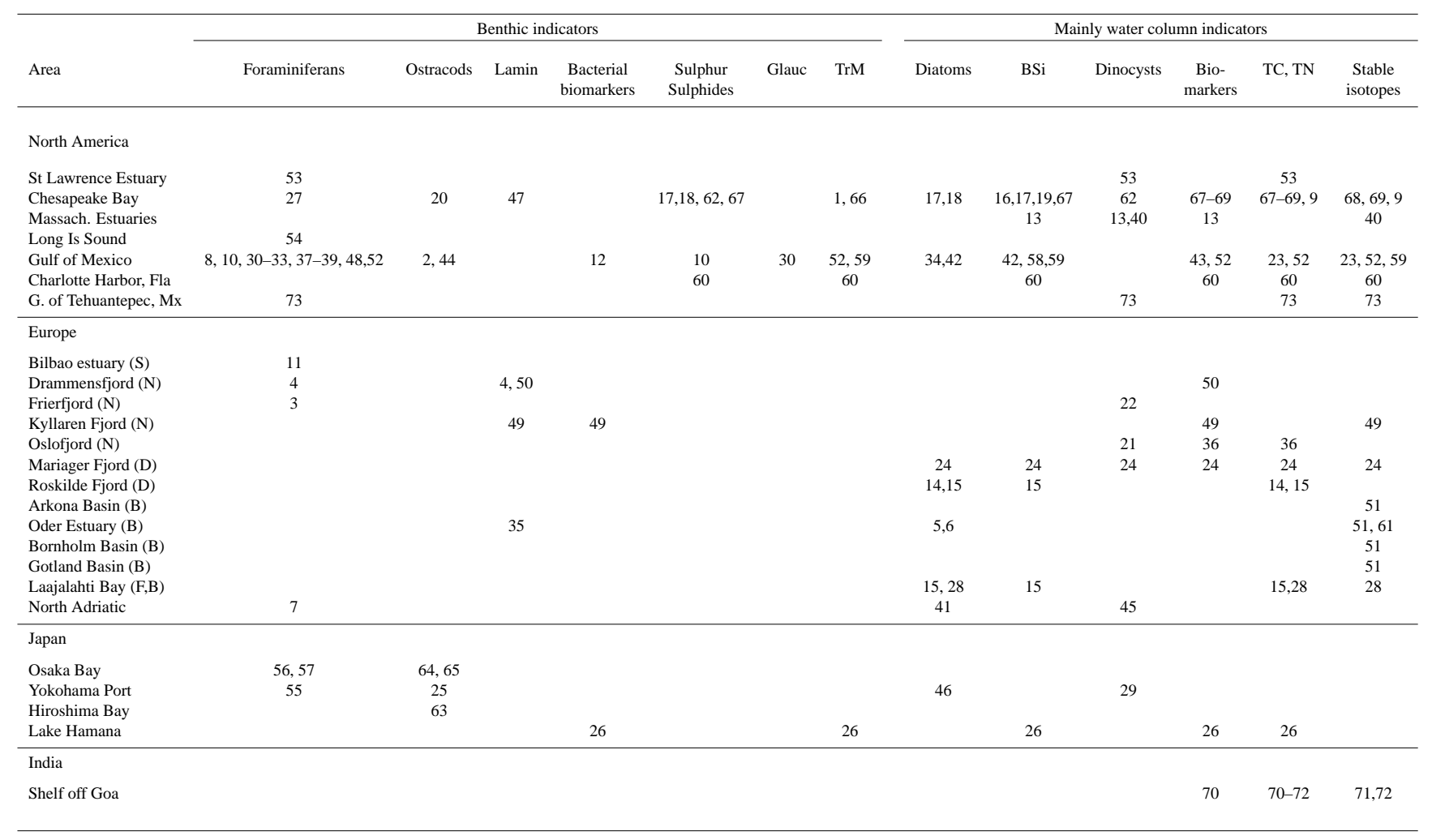

1) Adelson et al. (2001); 2) Alvarez Zarikian et al. (2000); 3) Alve (2000); 4) Alve (1991); 5) Andrén (1999); 6) Andrén et al. (1999); 7) Barmawidjaja et al. (1995); 8) Blackwelder et al. (1996); 9) Bratton et al. (2003) ; 10) Brunner (2006); 11) Cearreta et al. (2000); 12) Chen et al. (2001); 13) Chmura et al. (2004); 14) Clarke et al. (2003); 15) Clarke et al. (2006); 16) Colman and Bratton (2003); 17) Cooper (1995); 18) Cooper and Brush (1991, 1993); 19) Cornwell et al. (1996); 20) Cronin and Vann (2003); 21) Dale (2000); 22) Dale (2000); 23) Eadie et al. (1994); 24) Ellegaard et al. (2006) ; 25) Ikeya (1995); 26) Itoh et al. (2003); 27) Karlsen et al. (2000); 28) Kauppila et al. (2005); 29) Matsuoka (1999); 30) Nelsen et al. (1994); 31) Osterman (2003); 32) Osterman et al. (2005); 33) Osterman et al. (2007); 34) Parsons et al. (2002); 35) Persson and Jonsson (2000); 36) Pinturier-Geiss et al. (2002); 37) Platon and Sen Gupta (2001); 38) Platon et al. (2001); 39) Platon et al. (2005); 40) Pospelova et al. (2002); 41) Puškari et al. (1990); 42) Rabalais et al. (1996); 43) Rabalais et al. (2004); 44) Rabalais et al. (2002); 45) Sangiorgi and Donders (2004); 46) Sato (1995); 47) Schaffner et al. (1992); 48) Sen Gupta et al. (1996); 49) Smittenberg et al. (2004); 50) Smittenberg et al. (2005); 51) Struck et al. (2000); 52) Swarzenski et al. (2008); 53) Thibodeau et al. (2006); 54) Thomas et al. (2000, 2004); 55) Toyoda and Kitazato (1995); 56) Tsujimoto et al. (2006a); 57) Tsujimoto et al. (2008); 58) Turner and Rabalais (1994); 59) Turner et al. (2004); 60) Turner et al. (2006); 61) Voss and Struck (1997); 62) Willard et al. (2003); 63) Yasuhara et al. (2003); 64) Yasuhara and Yamazaki (2005); 65) Yasuhara et al. (2007); 66) Zheng et al. (2003); 67) Zimmerman and Canuel (2000); 68) Zimmerman and Canuel (2001); 69) Zimmerman and Canuel (2002); 70) Kurian et al. (2009); 71) D’Souza (2007); 72) Agnihotri et al. (2008); 73) Vásquez-Bedoya et al. (2008). 
Table 2. Indicators and their relationship to anoxia, hypoxia and eutrophication. See text for further details.

\begin{tabular}{|c|c|c|c|c|c|}
\hline Indicator & Anoxia & $\begin{array}{l}\text { Severe hypoxia } \\
(<5 \% \text { saturation }= \\
\left.0.2 \mathrm{ml} \mathrm{L}^{-1}\right)\end{array}$ & $\begin{array}{l}\text { Moderate } \\
\text { hypoxia }(5-30 \% \\
\left.=0.2-1.2 \mathrm{ml} \mathrm{L}^{-1}\right)\end{array}$ & $\begin{array}{l}\text { Eutrophication and increased } \\
\text { organic flux to seafloor }\end{array}$ & Comment \\
\hline \multicolumn{6}{|l|}{ Benthic indicators } \\
\hline Foraminiferans & Some species tolerant & $\begin{array}{l}\text { Decrease in species number and } \\
\text { diversity }\end{array}$ & $\begin{array}{l}\text { No influence on most } \\
\text { species }\end{array}$ & Strong influence on some species & $\begin{array}{l}\text { Anoxia-tolerant species may respire nitrate. } \\
\text { Interpretation of oxygen conditions con- } \\
\text { founded by organic enrichment. Some in- } \\
\text { dices based on foraminiferans (e.g. PEB in- } \\
\text { dex) may be applicable only locally }\end{array}$ \\
\hline Ostracods & Absent & $\begin{array}{l}\text { Decrease in diversity; a few tol- } \\
\text { erant species, some of which can } \\
\text { survive sulphidic conditions }\end{array}$ & Some tolerant species & $\begin{array}{l}\text { Abundance of some species may increase as a } \\
\text { result of eutrophication }\end{array}$ & $\begin{array}{l}\text { Most ostracods are intolerant of hypoxia. } \\
\text { Limited evidence suggests that ostracods } \\
\text { and foraminifers exhibit different responses } \\
\text { to hypoxia }\end{array}$ \\
\hline Bioturbation & Laminations & Incomplete laminations & $\begin{array}{l}\text { Bioturbation limited to a } \\
\text { few } \mathrm{mm} \text { to } \mathrm{cm} \text { at surface }\end{array}$ & $\begin{array}{l}\text { Sediments usually fully bioturbated, but in } \\
\text { Gulf of Mexico, small, surface deposit- } \\
\text { feeding opportunists that do not bioturbate are } \\
\text { abundant }\end{array}$ & $\begin{array}{l}\text { Laminations may also result from high sed- } \\
\text { imentation, regardless of overlying oxygen } \\
\text { conditions. }\end{array}$ \\
\hline Bio/ichnofacies & Traces and macrofossils absent & $\begin{array}{l}\text { Shelly exaerobic facies recog- } \\
\text { nised by bivalve shell detritus }\end{array}$ & $\begin{array}{l}\text { Decreasing penetration of } \\
\text { burrows with increasing } \\
\text { hypoxia }\end{array}$ & $\begin{array}{l}\text { Body and trace fossils usually common, but } \\
\text { not in all environments }\end{array}$ & $\begin{array}{l}\text { Oxygenated sediments with sufficient food } \\
\text { resources are occupied by a mature, diverse, } \\
\text { deep-burrowing benthos }\end{array}$ \\
\hline DOP & Values $>0.7$ & $0.55-0.70$ & & & $\begin{array}{l}\text { Reliable indicator for bottom-water oxy- } \\
\text { genation }\end{array}$ \\
\hline AVS:CRS & +++ & & & & $\begin{array}{l}\text { Useful indicator of anoxia, but depends on } \\
\text { sediment accumulation rate }\end{array}$ \\
\hline Glauconite & \multicolumn{5}{|c|}{ Mineral forms under hypoxic and anoxic conditions } \\
\hline${ }_{\delta}^{13} \mathrm{C}$ foram shell & & & & $\begin{array}{l}\text { Reflects uptake of photosynthetically fixed } \\
\text { carbon }\end{array}$ & \\
\hline$\delta^{13} \mathrm{C}$ organic matter & & & & $\begin{array}{l}\text { Eutrophication leads to raised } \delta^{13} \mathrm{C} \text { values due } \\
\text { to increased in situ marine phytoplankton pro- } \\
\text { duction }\end{array}$ & $\begin{array}{l}\text { Reflects relative contribution of terrestrial } \\
\text { and marine carbon sources }\end{array}$ \\
\hline$\delta^{15} \mathrm{~N}$ & & $\begin{array}{l}\text { Heavy values reflect denitrifica- } \\
\text { tion }\end{array}$ & & $\begin{array}{l}\text { Heavy values may reflect land derived } \mathrm{N} \text { and } \\
\text { eutrophication }\end{array}$ & $\begin{array}{l}\delta^{15} \mathrm{~N} \text { can be heavier when the nitrogen } \\
\text { source is from regeneration (e.g. } \mathrm{NH}_{4}^{+} \text {) }\end{array}$ \\
\hline$\delta^{34} \mathrm{~S}$ & $\begin{array}{l}\text { Increasing values indicate re- } \\
\text { ducing conditions }\end{array}$ & & $\begin{array}{l}\text { Lower values because of } \\
\text { active } S \text { re-oxidation cycle }\end{array}$ & & \\
\hline Sediment color and smell & $\begin{array}{l}\text { Dark with strong smell of sul- } \\
\text { phide }\end{array}$ & $\begin{array}{l}\text { Dark with strong smell of sul- } \\
\text { phide }\end{array}$ & & $\begin{array}{l}\text { Yellow to brown colour with smell of fresh or- } \\
\text { ganic matter }\end{array}$ & \\
\hline Magnetic properties of sediment & $\begin{array}{l}\text { Fine-grained, secondary min- } \\
\text { erals (e.g. greigite, pyrrhotite) } \\
\text { responsible for magnetic prop- } \\
\text { erties }\end{array}$ & & & $\begin{array}{l}\text { Coarse detrital minerals (e.g. haematite) re- } \\
\text { sponsible for magnetic properties }\end{array}$ & \\
\hline \multicolumn{6}{|l|}{ Water column indicators } \\
\hline Diatoms & Preservation may be enhanced & & & $\begin{array}{l}\text { Overall diatom production, and ratio of } \\
\text { planktonic (centric) to benthic (pennate) di- } \\
\text { atoms, increase with increasing eutrophica- } \\
\text { tion. Lightly silicified species may also in- } \\
\text { crease }\end{array}$ & Good indicators of eutrophication \\
\hline Dinocysts & $\begin{array}{l}\text { Enhanced preservation of } \\
\text { organic-walled cysts destroyed } \\
\text { in oxic conditions }\end{array}$ & \multicolumn{2}{|c|}{ A few species may be associated with hypoxia } & $\begin{array}{l}\text { Increases in heterotrophic cyst abundance of- } \\
\text { ten linked to eutrophication }\end{array}$ & $\begin{array}{l}\text { Species composition reflects productivity, } \\
\text { sea surface temperature, salinity, oxygena- } \\
\text { tion and enhanced preservation of certain } \\
\text { species under anoxic conditions. Some } \\
\text { species do not appear to respond consis- } \\
\text { tently to eutrophication. }\end{array}$ \\
\hline Trace metals: & $\begin{array}{l}\text { Enrichment in Mo indicates } \\
\text { anoxic, sulphidic conditions; } \\
\text { enrichment in } \mathrm{Rh} \text { indicates ab- } \\
\text { sence of free } \mathrm{H}_{2} \mathrm{~S}\end{array}$ & \multirow{2}{*}{\multicolumn{2}{|c|}{$\begin{array}{l}\text { High enrichment in vanadium, ura- } \\
\text { nium, but relative low enrichment in } \\
\text { Mo }\end{array}$}} & & $\begin{array}{l}\text { In anoxic conditions, most metals exist in } \\
\text { lower redox state (e.g. } \mathrm{Fe}^{2+}, \mathrm{Mn}^{2+} \text { ) and } \\
\text { form insoluble sulphide compounds. In } \\
\text { oxic conditions, metals exist in higher re- } \\
\text { dox state (e.g. } \mathrm{Fe}_{2} \mathrm{O}_{3} \text { and } \mathrm{MnO}_{2} \text { ) }\end{array}$ \\
\hline $\mathrm{BSi}$ & & & & Increases linked to eutrophication & Chemical indicator for diatom production \\
\hline Pigments and lipid biomarkers & Enhanced preservation & \multicolumn{2}{|c|}{$\begin{array}{l}\mathrm{DO}=0.28 \mathrm{ml} \mathrm{L}^{-1} \text { leads to enhanced preservation of } \mathrm{Chl} \text { a } \\
\text { and phaeopigments, compared to oxic conditions } \\
\text { Concentration of chlorins (Chl a breakdown products) in } \\
\text { sediments increases with lower DO in water column; how- } \\
\text { ever degradation rates not influenced by bottom-water DO }\end{array}$} & $\begin{array}{l}\text { Increased pigment and lipid concentrations } \\
\text { generally indicate increased primary produc- } \\
\text { tivity }\end{array}$ & $\begin{array}{l}\text { Biomarkers indicate relative abundance of } \\
\text { different phytoplankton taxa. Low oxy- } \\
\text { gen generally enhances preservation of } \\
\text { biomarkers in the sediment. }\end{array}$ \\
\hline $\begin{array}{l}\text { Pigments or lipids from green } \\
\text { pigmented sulphur bacteria } \\
\text { (isorenieratine, B-chl, farnesol) }\end{array}$ & Indicate photic zone anoxia & & & & $\begin{array}{l}\text { Derived from strictly anaerobic organisms } \\
\text { that require light and sulphide. B-chl in } \\
\text { sediments is hypoxia-specific proxy. }\end{array}$ \\
\hline
\end{tabular}




\section{Sedimentary indicators of hypoxia and eutrophication}

\subsection{Faunal indicators}

Microfossils derived from prokaryote, protistan and metazoan organisms have been used for many years as indicators of palaeoenvironmental conditions in the geological past (Lipps, 1993). Their application to historical time scales is a more recent development that falls within the scope of environmental micropalaeontology (Martin, 2000; Haslett, 2002). Although many dominant macro- and meiofaunal groups (e.g. polychaetes and nematodes) are almost never preserved intact, some small benthic organisms, notably the Foraminifera and Ostracoda, have outstanding fossil records and may be used to trace the responses of benthic communities to past environmental changes. A main advantage of microfossils over larger macrofossils is that numerous complete specimens can be recovered from relatively small sediment samples. Disadvantages include the fact that they are easily transported, possibly resulting in assemblages that include a significant allochthonous component, and can undergo considerable taphonomic alteration (Murray, 1976; Loubere et al., 1993; Loubere, 1997). Moreover, fossil assemblages are normally time-averaged. Extended anoxic periods will result in sediments devoid of microfossils, except where allochthonous elements have been transported laterally. If the study area has been subject to one or more short reoxygenation phases, the time-averaged deposit will contain autochthonous faunal remains. In many cases, especially when the time period under consideration has been dominated by anoxia, the microfossils present will be typical for the most oxygenated conditions which occur at the site. An alternation of anoxia with varying degrees of hypoxia will result in a complex faunal mix, making it impossible to unravel the exact oxygenation history from the time-averaged sample. Historical studies of oxygen depletion often disregard this problem.

In this section, we consider benthic faunal indicators that primarily reflect conditions in and on the sediment and not necessarily in the overlying water column. In most coastal sediments oxygen is depleted within the first $1-2 \mathrm{~cm}$ of the sediment column. Sediments underlying anoxic bottom waters differ from anoxic sediments underlying normal, oxygenated bottom waters because they contain different benthic communities and re-oxidation of reduced substances does not occur. This has major consequences for sediment energy balance and metabolism (e.g., the significance of chemoautotrophic communities) and nutrient exchange across the sediment-water interface (efficient recycling or retention of nitrogen and phosphorus) (Middelburg and Levin, this volume). As indicated above, the separate effects of hypoxia and eutrophication are difficult to disentangle, and it is often unclear which is exerting the predominate influence on assemblages of indicator species.

\subsubsection{Foraminifera}

Following recent molecular phylogenetic studies (Schweitzer et al., 2007), we consider the order Rotaliida to include groups such as the buliminids, bolivinids and cassidulinids, which constituted a distinct order, the Buliminida, in some earlier classifications.

Jorissen et al. (2007) give an overview of faunal proxies based on foraminiferans, the most widely-used benthic taxon for palaeo-reconstructions of bottom-water hypoxia and other environmental parameters (Murray and Alve, 2002; Murray, 2006). These testate protists are distributed in all marine environments. They have an outstanding fossil record and are sensitive indicators of environmental conditions including hypoxia. Foraminiferans are more tolerant of hypoxia than most metazoan taxa, although, with the likely exception of Virgulinella fragilis, which is found world-wide in coastal and deeper-water, oxygen-deficient, sulphidic settings (Tsuchiya et al., 2009), no species is confined to hypoxic environments. Foraminiferans are particularly abundant on the seafloor off major rivers and in other productive areas (Phleger, 1976; Van der Zwaan and Jorissen, 1991). Some species have physiological mechanisms that enable them to withstand severe hypoxia and even anoxia (Moodley et al., 1997; Bernhard and Sen Gupta, 1999; RisgaardPetersen, 2006), but all species disappear when anoxia is prolonged (Alve, 1990, 1991; Schmiedl et al., 2003). The disappearance of foraminiferans may be linked to the toxic effects of hydrogen sulphide. Their absence in some heavily polluted areas may also be caused by heavy metals (Cearreta et al., 2002) or lowered pH (Green et al., 1993; Mojtahid et al., 2008).

Foraminiferal assemblages in hypoxic environments are typically of low species richness and dominated by a few hypoxia-tolerant species. Hyaline taxa (Rotaliida), particularly chilostomellids, nonionids, uvigerinids, buliminids and bolivinids, usually predominate while agglutinated and porcelanous (miliolid) species are uncommon. The rotaliids often have thin-walled tests with flattened, elongate biserial/triserial, planispiral/lenticular or globular morphologies (Sen Gupta and Machain-Castillo, 1993; Bernhard and Sen Gupta, 1999). Two typical hypoxia-tolerant genera, Globobulimina and Chilostomella, include deepinfaunal species that live around and immediately below the zero-oxygen level in sediments with a well-oxygenated sediment/water interface (Jorissen, 1999a). Species of the Bolivina/Brizalina/Uvigerina group have traditionally been regarded as infaunal, in contrast to trochospiral rotaliids such as Cibicidoides, which are often considered to be epifaunal (Corliss, 1985; Jorissen, 1999a), although there is no compelling evidence that these two groups occupy distinct microhabitats.

Benthic foraminiferans have been used to trace the development of bottom-water hypoxia in fjords, estuaries, and off major rivers such as the Mississippi and the Po (Sen Gupta et 
al., 1996; Murray and Alve, 2002). Environmental changes have been inferred from a variety of faunal characteristics. Depressed species richness and diversity, combined with increasing dominance by single species, are often signs of increasing oxygen depletion (Phleger and Soutar, 1973; Gooday et al., 2000; Schmiedl et al., 2003; Brunner et al., 2006). Fluctuations in the abundance of foraminiferal tests in sediment records reflect organic matter flux to the seafloor, as long as sedimentation rates are fairly constant (Herguera and Berger, 1991). Both abundance and diversity decreased dramatically in some parts of Frierfjord, Norway, coincident with the onset of the modern industrial period around 1870 (Alve, 2000). These parameters also declined during the 20th Century in cores from the Mississippi Delta Bight (Blackwelder et al., 1996; Sen Gupta et al., 1996; Platon and Sen Gupta, 2001; Platon et al., 2005). In other cases, however, strongly hypoxic areas have extremely high foraminiferal densities, although diversity remains depressed (Phleger and Soutar, 1973; Gooday et al., 2000). Large standing stocks of a few hypoxia-tolerant species may reflect the disappearance of macrofaunal and meiofaunal predators combined with an abundant food supply. On the Pakistan margin of the Arabian Sea, foraminiferans replace the metazoan macrofauna as the principal consumers of organic matter at oxygen concentrations below 5-7 $\mu \mathrm{M}$ (Woulds et al., 2007).

Many studies in coastal environments subject to hypoxia report an increase over time (i.e. upcore) in the proportion of hypoxia-tolerant species (mainly rotaliids) and a corresponding decrease in hypoxia-intolerant species (most miliolids and agglutinated species) (Nelsen et al., 1994). A core from the northern Adriatic Sea southeast of the Po River delta revealed a gradual change from an assemblage typical of unstressed, oxic environments, including epiphytic habitats, to one that indicated a food-rich, hypoxic environment (Barmawidjaja et al., 1995). The buliminid Stainforthia fusiformis is a particularly useful indicator of hypoxia in Norwegian fjords (Alve, 2003; Husum and Alve, 2006). A transition from dominance by Cassidulina laevigata in sediments deposited before the establishment of modern industries (pre 1870) to dominance by $S$. fusiformis in the later part of the 20th Century has occurred in Frierfjord (Alve, 2000). In Drammensfjord, fluctuations in the benthic environment over a 1500-year period are indicated by species typical of oxygenated habitats (e.g. Adercotryma glomeratum, Cassidulina laevigata, Cribrostomoides kosterensis, Elphidium excavatum, Nonion labradorensis) and oxygen-deficient habitats (Spiroplectammina biformis, Stainforthia fusiformis) (Alve, 1991). Conditions in this fjord have deteriorated since the middle of the 19th Century, culminating in barren, partly laminated sediments deposited during the last 15-20 years. Similar trends were apparent in two cores from the Lower St. Lawrence Estuary, Canada (Thibodeau et al., 2006). Since $\sim 1960$, the accumulation rate of dead benthic foraminiferal tests increased, together with the appearance and progressive increase in abundance of two buliminid species, Brizalina subaenariensis and Bulimina exilis. These changes were interpreted to indicate a rise in the flux of organic carbon to the seafloor, accompanied by increasingly hypoxic conditions. The enhanced abundance of these species may also reflect the disappearance of less tolerant competitors.

Ammonia species (Fig. 3) typically dominate foraminiferal faunas in brackish (mesohaline) and polyhaline coastal and estuarine environments where they can tolerate severe hypoxia and even, for a time, anoxic conditions. Thomas et al. (2000) compared samples collected in the early 1960s and the late 1990s in the western part of Long Island Sound (LIS). They reported an increase in the relative abundance of Ammonia beccarii, a decrease in the abundance of Elphidium excavatum clavatum, and a decrease in foraminiferal diversity over this period. Historical records in cores from LIS revealed similar trends (Thomas et al., 2004). These changes may reflect seasonal anoxia, eutrophication related to sewage inputs (Thomas et al., 2000) or changes in phytoplanktonderived food sources (Thomas et al., 2004; see below). Tsujimoto et al. (2006b) observed a striking increase in the abundance of Ammonia beccarii and two agglutinated species, Trochammina hadai and Eggerella advena, in a core (OBY) from the innermost part of Osaka Bay, Japan, starting at a level in the core corresponding to $\sim 1920$. They attributed this trend to increased bottom-water hypoxia related to eutrophication. Since $\sim 1990$, however, A. beccarii has undergone a sharp decrease in abundance, while E. advena and a fourth species, Uvigerinella glabra, which was previously rare, have both increased. The authors suggest that this latest faunal shift may be related to a change from a dinoflagellatedominated to a diatom-dominated food supply. Three cores from a transect extending from the OBY site away from the mouth of the Yodo River also exhibited increases in $E$. $a d$ venta, $A$. beccarii and T. hadai, but these were generally more subdued than in core OBY and started later (Tsujimoto et al., 2008). Other species have declined in importance at the two inner sites, starting in the early 1990s in the case of OBY and after the 1940s to 1960s in the case of OS3.

Karlsen et al. (2000) reported fluctuating percentages of Ammonia in cores from Chesapeake Bay spanning a 500year time period. They linked a dramatic increase in the late 20th Century, and a corresponding decline in the abundance of Elphidium selseyensis and Ammobaculites, to environmental changes related to fertilizer use, nutrient loading and oxygen depletion. However, the Ammonia record yielded evidence of seasonal anoxia in some years between 1900 and 1960 and episodically in the main channel between 1600 and 1900 (Willard and Cronin, 2007) (Fig. 4), as is also evident in the ostracod record (see below). A similar relationship between Ammonia and Elphidium on the inner shelf of the Gulf of Mexico (Rabalais et al., 1996) was used by Sen Gupta et al. (1996) to propose the Ammonia-Elphidium (A-E) index $\left(\left[\mathrm{N}_{A} / \mathrm{N}_{A}+\mathrm{N}_{E}\right] \times 100\right.$, where $\mathrm{N}_{A}$ is the number of specimens of Ammonia and $\mathrm{N}_{E}$ the number of specimens of Elphidium in a sample) as an indicator of hypoxia. The 


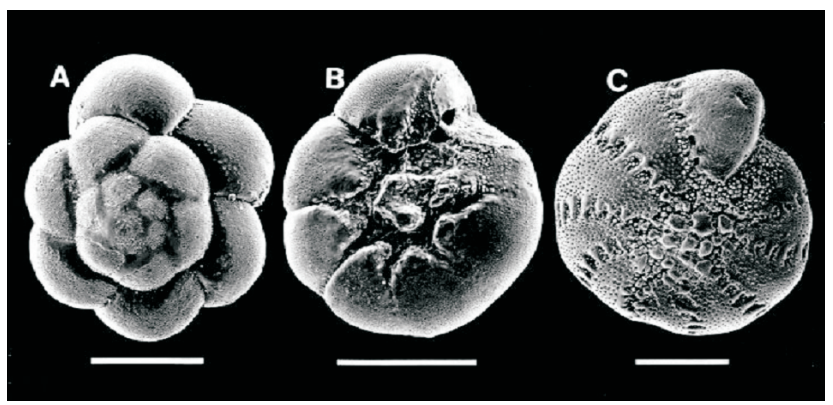

Fig. 3. Scanning electron micrographs of benthic foraminiferans with different tolerances to hypoxia. ( a-b) Ammonia parkinsoniana; (c) Elphidium excavatum. Specimens are from the Louisiana shelf, west of the Mississippi Delta. Scale bars $=100 \mu \mathrm{m}$. (From Geology, Vol. 24, Sen Gupta, B. K., Turner, R. E. and Rabalais, N. N., Seasonal oxygen depletion in continental-shelf waters of Louisiana: Historical records of benthic foraminifers, 227-230, 1996, copyright Geological Society of America.)

A-E index possibly reflects factors other than oxygen, for example, the relative availability of different food sources, in addition to oxygen itself (Brunner et al., 2006). Thomas et al. (2004) attributed a strong increase in the relative abundance of Ammonia at the expense of Elphidium during the 1960s in Long Island Sound to a switch from diatom- to cyanobacteria/dinoflagellate-dominated phytoplankton production, linked to an increase in $\mathrm{N}$-rich effluent and hence $\mathrm{N} / \mathrm{Si}$ ratios. The environmental controls on the A-E index therefore may be quite complex and probably differ in different geographical settings. Nevertheless, this index has yielded plausible interpretations of historical core records, at least in Chesapeake Bay (Sen Gupta and Platon, 2006) and the Gulf of Mexico (Sen Gupta et al., 1996). Historical trends were clearly evident in three cores from the inner shelf (10 $30 \mathrm{~m}$ ) of the Gulf of Mexico where hypoxia is prevalent, but not in a core from a deeper $(50 \mathrm{~m})$ site not subject to hypoxia where Ammonia and Elphidium were less common and the A-E index was highly variable (Sen Gupta et al., 1996; see also Brunner et al., 2006).

Other foraminiferan-based indices have been applied in somewhat deeper water where Ammonia and Elphidium are uncommon. Together with previous authors (Nelsen et al., 1994; Blackwelder et al., 1996; Platon and Sen Gupta, 2001), Osterman (2003) observed that the combined percentage of three foraminiferal species (Pseudononion atlanticum, Epistominella vitrea and Buliminella morgani) was highest in surface sediment samples from hypoxic areas at mid-shelf depths $(30-70 \mathrm{~m})$ off Louisiana. She termed this percentage the PEB Index and used it to reconstruct trends in bottomwater oxygenation over a 180-year period (Osterman et al., 2005). Later, Osterman et al. (2007) extended coverage of the PEB Index to other parts of the Lousiana shelf and also examined a much longer time period in three gravity cores, including one obtained within the modern hypoxic zone. In

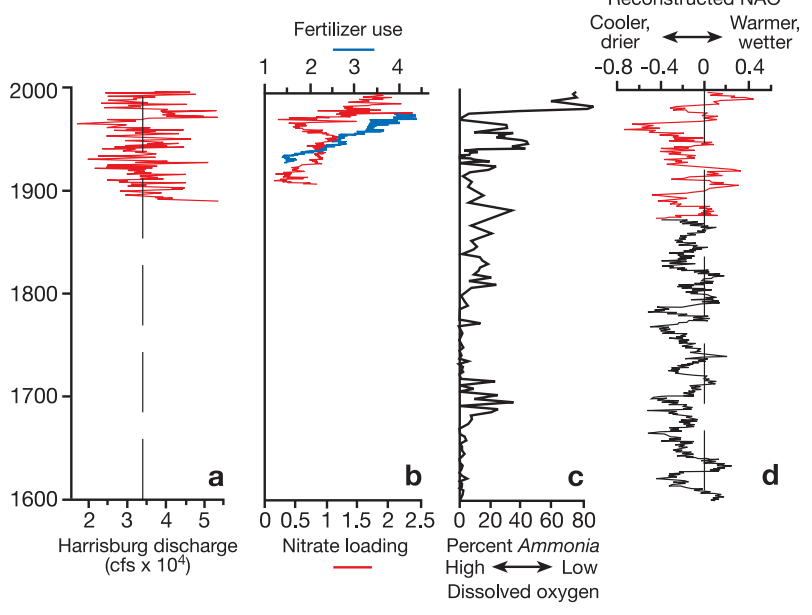

Fig. 4. Instrumental (red and blue lines) and proxy-based (black lines) records of (a) fluvial discharge at Harrisburg, Pennsylvania; (b) fertilizer in Chesapeake Bay watershed (blue line) and nitrate loading to Chesapeake Bay (red line); (c) dissolved oxygen based on percent abundance of Ammonia; (d) North Atlantic Oscillation Index (NAO) reconstructed from tree-ring records. (Redrawn from Frontiers in Ecology and the Environment, Vol. 5, Willard, D. A. and Cronin, T. M., Paleoecology and ecosystem restoration: case studies from Chesapeake Bay and the Florida Everglades, 491-498, 2007, with permission from The Ecological Society of America.)

addition to a sharp rise in the PEB Index since the 1950s, this core revealed periodic peaks over the last 1000 years. These probably reflect natural low-oxygen events related to decadal-scale increases in discharges from the Mississippi River (see also Swarzenski et al., 2007). In contrast, no trends in the PEB Index were evident in a core from $60 \mathrm{~m}$ water depth NE of the Mississippi Delta (Brunner et al., 2006). This index is probably only applicable locally; not all of the species concerned are widely distributed in hypoxic environments. Buliminella morgani is apparently endemic to the Gulf of Mexico and E. vitrea is associated with well-oxygenated water masses elsewhere (Pawlowski et al., 2007). Recently, Platon et al. (2005) proposed an "agglutinated-porcelanous index" (A-P index) as a possible palaeohypoxia proxy, based on cores from the Mississippi Delta Bight where the A-P index declined sharply after the early 1940s as the proportion of hyaline foraminiferans increases (see also Nelsen et al., 1994) (Fig. 5). The A-E, PEB and A-P indices are useful indicators of historical hypoxia in coastal settings, although they do not correspond to precise bottom-water oxygen values.

Possible links have been suggested between foraminiferal test morphology and bottom-water oxygenation. In a core from Yokohama Bay spanning a period of about 100 years, Toyoda and Kitazato (1996) recognised morphotypes of three dominant species (Trochammina hadai, Ammonia beccarii and A. japonica), with lobate and smooth outlines. Lobate 

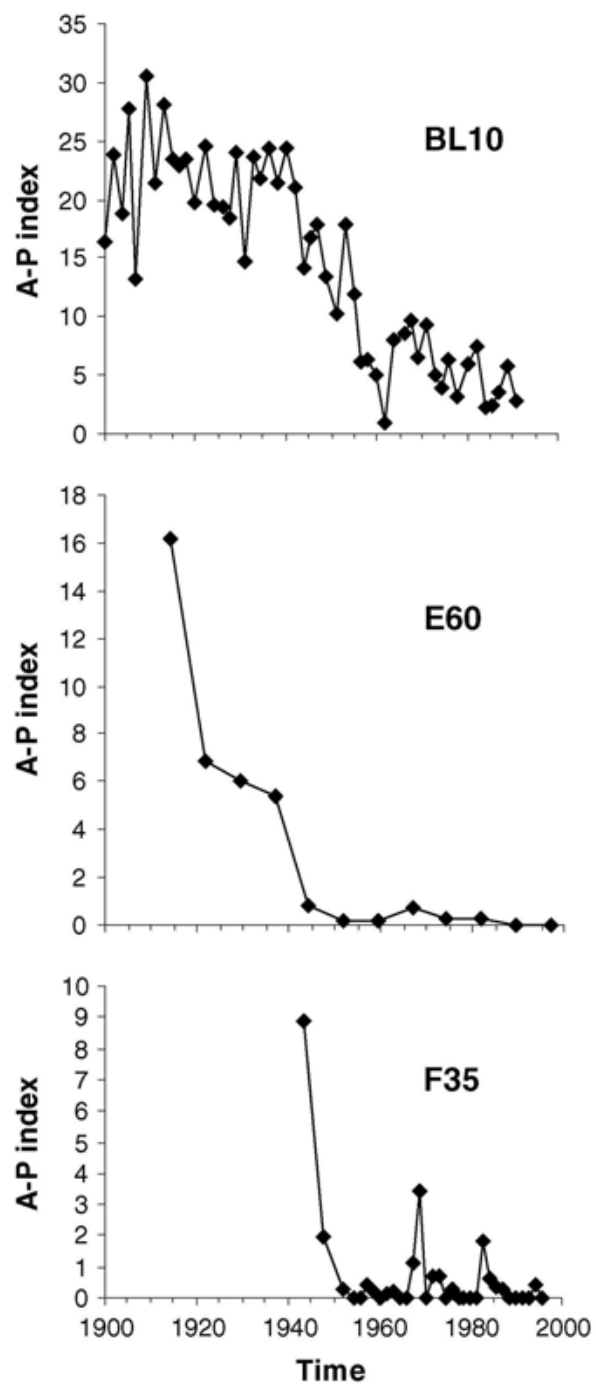

Fig. 5. The ratio between the abundance of agglutinated and porcelanous foraminiferans (the A-P Index) in three cores from the Louisiana inner continental shelf, SW of the Mississippi Delta: BL10 (29 m water depth), F35 (35 m depth), E60 (60 m). (Reprinted from Marine Micropaleontology, Vol. 54, Platon, E., Sen Gupta, B. K., Rabalais, N. N., and Turner, R. E.: Effect of seasonal hypoxia on the benthic foraminiferal community of the Louisiana inner continental shelf: the 20th century record, 263-283, 2005, with permission from Elsevier. )

tests were considered to be more typical of oxygenated conditions whereas the smooth forms were associated with oxygen depletion. Jorissen (1987) attributed similar morphotype variations in A. parkinsonia/tepida, Elphidum granosum and E. poeyanum from the northern Adriatic Sea to higher organic input, leading to an accelerated growth and thinner, more lobate chambers, in addition to reduced oxygen concentrations (note that this is the opposite relationship to that reported by Toyoda and Kitazato). Also in the northern Adriatic Sea, Bulimina marginata exhibited a correlation between an inferred oxygen gradient and test morphology, with morphotypes lacking spinose ornamentation being present in the areas with highest organic input (and lowest oxygen concentrations). It has been suggested that deformed Ammonia tests in Chesapeake Bay are associated with hypoxia (Karlsen et al., 2000).

Stable carbon isotope ratios in calcareous foraminiferal tests provide an additional tool for reconstructing historical environments, in particular organic carbon delivery to sediments. Increased organic matter inputs typically lead to more depleted carbon isotope signatures of pore water dissolved inorganic pools because respiration of organic matter adds carbon dioxide that is depleted in ${ }^{13} \mathrm{C}$. Accordingly, benthic foraminiferans extracting carbonate from this ${ }^{13} \mathrm{C}$ depleted pore-water pool will be characterised by isotopically lighter $\delta^{13} \mathrm{C}$ values. In two cores from the Mississippi Delta Bight, $\delta^{13} \mathrm{C}$ values obtained from multispecies benthic foraminiferal samples, and from Buliminella morgani, were about $0.6-1.0 \%$ heavier before the mid-1960s compared to those derived from later sediments (Eadie et al., 1994). A similar trend was reported by Thomas et al. (2000) in Long Island Sound where calcareous tests collected in 1961 were isotopically slightly heavier than those collected in 1996/1997. The authors inferred from these results that the amount of oxidizable organic carbon had increased over this 35 year time period. They suggested that the magnitude of the shift could be used as an proxy for the occurrence and severity of past anoxic episodes in Long Island Sound. The decrease in ${ }^{13} \mathrm{C}$ in atmospheric $\mathrm{CO}_{2}$ caused by the consumption of fossil fuel with low ${ }^{13} \mathrm{C}$ values, the so-called Suess effect (Suess, 1955; Verburg, 2007), may also influence these trends.

Foraminiferans respond to a complex set of environmental parameters. In coastal environments, these include the quantity, quality and regularity of food inputs, salinity, current and wave activity, as well as oxygen (Murray, 2001, 2006). Since many foraminiferans can tolerate low-oxygen conditions, food inputs may be more important than oxygen stress. Nevertheless, because of the apparent robustness of the correlation between organic input and bottom-water oxygen conditions, at least on a local to regional scale, the foraminiferal response may indeed yield valuable information about past oxygen levels.

\subsubsection{Benthic Ostracoda}

Ostracods are crustaceans that live in the upper $1 \mathrm{~cm}$ of freshwater and marine sediments where they form part of the metazoan meiofauna. Their calcified bivalved shells are commonly preserved as fossils, usually as disarticulated valves. Like foraminiferans, they are sensitive indicators of environmental conditions, including changes caused by human impacts (Ruiz et al., 2005). They respond to salinity and bottom-water oxygenation with assemblages 
in stressed environments often being dominated by single species (Boomer, 2002). Unlike foraminiferans, and in common with most crustacean taxa (e.g. Moodley et al., 1997), they usually are intolerant of hypoxia, although a few marine and brackish-water species are exceptions (Modig and Ólafsson, 1998; Cronin and Vann, 2003; Whatley et al., 2003; Ruiz et al., 2005; Corbari et al., 2005). Cyprideis torosa, one of the most abundant metazoans in coastal Baltic waters, survives in sulphidic habitats by oxidizing sulphide to thiosulphate (Jahn et al., 1996). Under hypoxia, this species can use anaerobic metabolic pathways to detoxify sulphide, allowing it to survive these extreme conditions for a considerable time. Two other Baltic species, Heterocyprideis sorbyana and Candona neglecta, may have similar capabilities (Modig and Ólafsson, 1998).

Ostracods are much less common than foraminiferans in sediment cores, and usually play a supporting role in historical reconstructions (e.g. Alve, 1991). Only a few studies focus specifically on ostracods as tracers of anthropogenic environmental change in coastal environments. Nevertheless, these crustaceans hold considerable promise as indicators of trends in hypoxia. Alvarez Zarikian et al. (2000) analysed assemblages along a $50-\mathrm{cm}$-long core from a severely hypoxic area on the inner shelf off Louisiana, spanning the period from 1904 to 1993. One genus, Loxoconcha, dominated $(>70 \%)$ modern ostracod assemblages associated with severely hypoxic conditions at the top of the core and decreased in relative abundance downcore. The relative abundance of this species corresponded closely to the record of fertilizer application in the US, a proxy for nutrients discharged by the Mississippi River, and suggested that the coring site became hypoxic $\left[\mathrm{O}_{2}=0.1-1.0 \mathrm{ml} \mathrm{L}^{-1}(=4.3-43 \mu \mathrm{M})\right]$ in the mid-1940s. The overall species diversity of ostracods in this core also declined in more recent sediments (Rabalais et al., 2002) (Fig. 6).

An important study by Cronin and Vann (2003) applied information on modern ostracod assemblages in Chesapeake Bay to reconstruct trends in salinity, dissolved oxygen and turbidity over a 500-year period based on a core obtained from the bay at the mouth of the Patuxet River (Chesapeake Bay). One particular species, Cytheromorpha curta, was able to tolerate periodic anoxia as well as high turbidity and a wide range of salinities, whereas most other species required oxygenated water but tolerated different salinity and turbidity levels. Shifts in species abundances suggested natural environmental variability, including periods of hypoxia, related to climatic fluctuations during the 16th and 17th Centuries (Fig. 7a). Human impacts became apparent during the past 200 years. A striking feature of this record is the dramatic increase in the abundance of $C$. curta since the 1960 s, coupled with the virtual disappearance of other ostracod species (Fig. 7b). Cronin and Vann (2003) consider the increased intensity of seasonal anoxia to be the most likely explanation for this recent faunal shift.
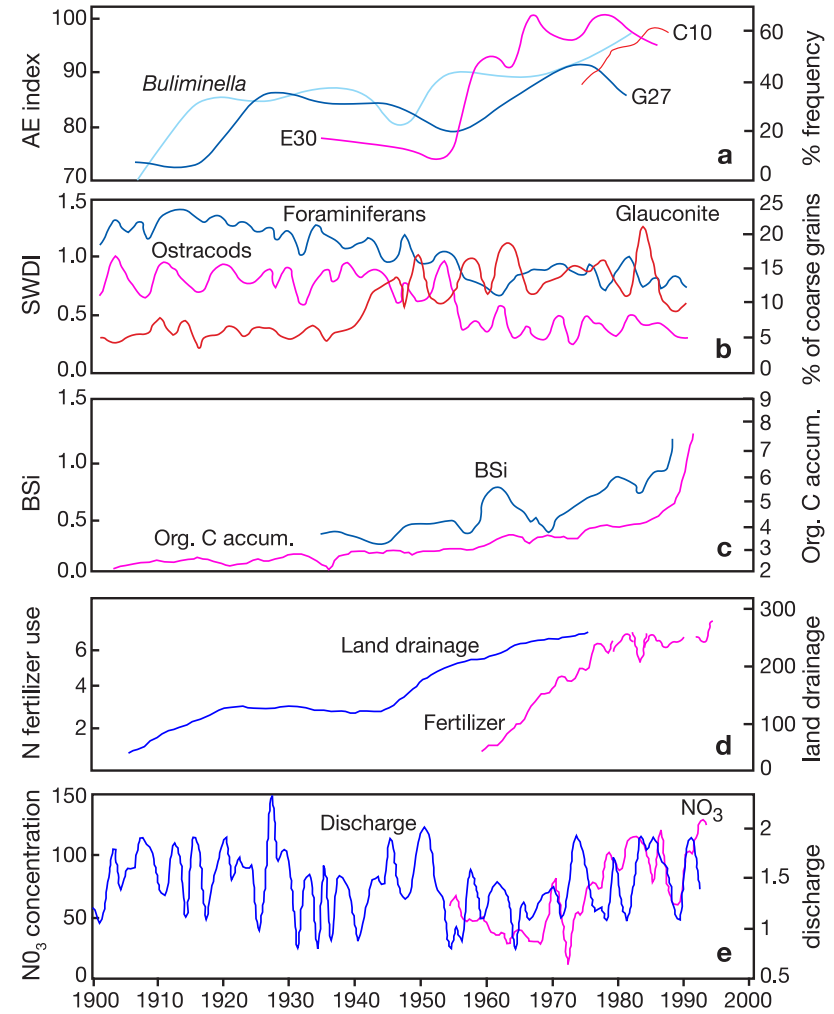

Fig. 6. Trends in faunal and environmental parameters in cores from the Louisiana coast, west of the Mississippi River delta. (a) The ratio between the abundance of Ammonia and Elphidium (A-E index) in three cores $(\mathrm{C} 10, \mathrm{E} 30, \mathrm{G} 27)$, and the percentage abundance of Buliminella (G27). (b) Shannon-Wiener diversity index (SWDI) for foraminiferans and ostracods and the percentage of the mineral glauconite among the coarser sediment grains. (c) Frequency of biologically bound silica (BSi) in core E30 and organic carbon accumulation rate. (d) Nitrogen fertilizer use in the Mississippi River basin and land drainage. (e) Nitrate concentration in the lower Mississippi River and lower Mississippi River discharge. ( Reprinted from Ecological Applications, Vol. 15, supplement, Rabalais, N. N., Turner, R. E., Sen Gupta, B. K., Platon, E., and Parsons, M. L.: Sediments tell the history of eutrophication and hypoxia in the northern Gulf of Mexico, S129-S143, 2007, with permission from The Ecological Society of America. )

Yasuhara et al. (2007) described changes in ostracod abundance, diversity and faunal composition in four cores taken along a transect from the innermost part of Osaka Bay (Japan) near the mouth of the Yodo River, to the centre of the Bay. The total abundance of ostracods decreased from 1910-1920 at the innermost station (OBY) and from $\sim 1960$ at the next (inner) station (OS3) along the transect. Since $\sim 1970$, abundance has been very low $(<20$ specimens per $20 \mathrm{~g}$ dry sediment) at these two sites. Although the absolute abundances of all species decreased, the relative abundances of Bicornucythere bisanensis, B. sp., Cytheromorpha acupunctata and Loxoconcha viva increased. These trends 

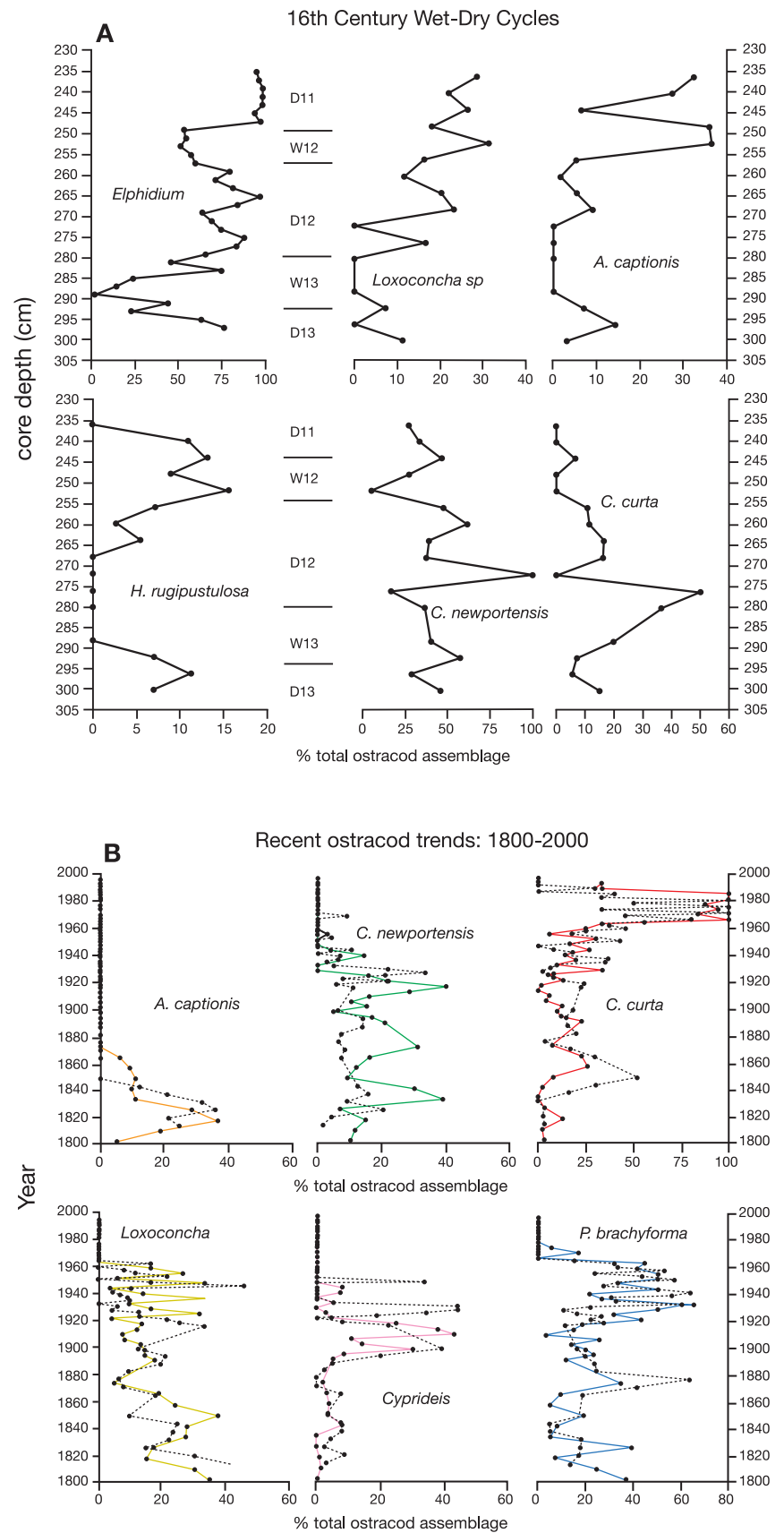

Fig. 7. Ostracod records based on piston and gravity core samples from Chesapeake Bay, off the mouth of the Patuxent River (PTXT site). (a) Decadal-scale variability in 5 ostracod species and 1 foraminiferal species in sediments from a piston-core representing the period 1500 $1650 \mathrm{AD}$, which featured three wet/dry climatic cycles (D11-13, W12-13). Distinct ostracod assemblages characterize each dry and wet period, reflecting inferred salinity, turbidity and oxygen conditions. (b) Variability in the abundance of 6 ostracod species during the past 200 years based on a piston core (PTXT-2-P-5, solid line in colour) and a gravity core (PTXT-2-G-3, dashed line). (From Estuaries, Vol. 26, Cronin, T. M. and Vann, C. D.: The sedimentary record of climatic and anthropogenic influence on the Patuxent Estuary and Chesapeake Bay ecosystems, 196-209, 2003, with permission from Springer.)

were attributed to eutrophication, which accelerated during the 1950s and peaked between 1960 and 1970, combined with summer hypoxia, which reached a maximum in the 1970s. Hypoxia only affected the inner part of the bay. At the outer two stations, eutrophication in the absence of hypoxia led to an increase in ostracod abundance. Rather 
surprisingly, these 100-200-yr sediment records revealed no major changes in ostracod diversity at any of the four stations in Osaka Bay. Yasuhara et al. (2003) reported similar patterns in Hiroshima Bay. Ostracod abundances decreased from the 1940s in the inner bay while the relative abundance of B. bisanensis increased and diversity remained relatively stable over the $100-y r$ record.

Direct comparisons of the responses of ostracods (metazoans) and foraminiferans (protists) to environmental impacts are rare. An illustration in Rabalais et al. (2002), reproduced here as Fig. 6, shows a similar decreasing trend in ostracod and foraminiferal diversity (Shannon-Wiener index) from 1900 to 1990 in the northern Gulf of Mexico. Over shorter time scales, oscillations in the diversity of the two taxa show some correspondence, although the match is not precise. As mentioned above, ostracod abundance in Osaka Bay began to decline at the innermost, hypoxia-influenced station (OBY) around 1910-1920 while diversity remained stable (Yasuhara et al., 2007). In the same core, foraminiferans increased in abundance from $\sim 1920$ to $\sim 1965$ before undergoing a relatively modest decrease (Tsujimoto et al., 2006b), while diversity decreased substantially after $\sim 1920$. This suggests foraminiferans and ostracods exhibit different responses to hypoxia, with certain foraminiferal species being more tolerant than the ostracods.

\subsubsection{Juvenile molluscs}

Alve (2000) noted abundance peaks in juvenile gastropods and bivalves in the upper sections (dating from $\sim 1870$ onwards) of cores from $>70 \mathrm{~m}$ water depth in Frierfjord, Norway. She attributed these peaks, which were accompanied by a strong dominance of the hypoxia-tolerant foraminiferan Stainforthia fusiformis, to the lethal affects of anoxia on the juvenile molluscs. Similar patterns were observed in Drammensfjord (Alve, 1991). Why elevated densities of recruits should occur under these conditions is not clear. Possibly, they reflect brief periods of re-oxygenation leading to a transient settlement event, as reported for the opportunistic bivalve Abra aequalis on the Texas continental shelf (Harper et al., 1991).

\subsubsection{Sediment laminations and trace fossils}

A variety of mechanisms can generate laminations (varves) but all require that the laminated sediment fabric is not totally disrupted by bioturbation (Kemp et al., 1996), physical disturbance, or the burrowing activities of larger animals such as echinoderms and molluscs. In marine environments, this usually happens when the macroinfauna are eliminated by severe hypoxia, as occurs in the core regions of some open-ocean oxygen minimum zones (OMZs) (van Geen et al., 2003; Levin et al., 2009), silled basins with restricted circulation (Thunnell et al., 1995; Zillén et al., 2008; Conley et al., 2009), and in some fjords (Alve, 2000). Laminations are also developed off major rivers where sediment deposition rates are so high that macrofaunal populations cannot be maintained (Rabalais, unpublished observations). Modern laminated sediments are not always devoid of eukaryotic life; some habour large numbers of foraminiferans and nematodes that cause bioturbation on a microscopic scale not apparent to the naked eye (Pike et al., 2001). Recent studies suggest that degraded laminations may persist where macroinfauna begin to reappear in the lower parts of OMZs, although they disappear as oxygen levels rise and macrofaunal densities increase (Levin et al., 2009).

Bioturbation disturbs sediments but it also provides important environmental information (Savrda and Bottjer, 1991; Levin et al., 2000). Sequences of laminated and bioturbated sediments have been used to reconstruct Quaternary climatic fluctuations, notably in the Santa Barbara Basin $(576 \mathrm{~m}$ water depth) on the Californian margin (Behl, 1995; Behl and Kennett, 1996). Laminations have also been used to infer hypoxic conditions in more recent historical records. A shift from laminated to bioturbated sediments since the 1970s has been interpreted, in combination with changing foraminiferal $\delta^{13} \mathrm{C}$ values, as signifying reduced carbon oxidation rates and a $15-20 \mu \mathrm{M}$ increase in dissolved oxygen concentrations at the edges of several southern California borderland basins. These changes correspond to a $20-30 \%$ reduction in upwelling and a $1.5-3^{\circ} \mathrm{C}$ increase in temperature and suggest climatic influences on productivity (Stott et al., 2000). In deeper parts of Drammensfjord $(\sim 110 \mathrm{~m})$, pyrite-containing laminations indicate that hypoxic conditions have persisted throughout the last $1000 \mathrm{yrs}$ (Alve, 1990, 1991; Smittenberg et al., 2005). Laminations are developed in other Norwegian fjords, for example, at 29-m depth in the Kyllaren Fjord (Smittenberg et al., 2004). In the Baltic Sea, hypoxia leading to the formation of sediment laminations has become widespread since the 1950s in the deeper basins (150-459 m; Jonsson et al., 1990; Conley et al., 2002; Zillén et al., 2008), as well as in shallower areas $(12-50 \mathrm{~m}$; Persson and Jonsson, 2000) (Fig. 8). This recent expansion in the extent of laminated sediments is attributed to human influences. However, laminated intervals in cores spanning longer time scales reveal that the Baltic basins have been periodically hypoxic throughout the Holocene, as a result of climatic forcing (Zillén et al., 2008; Conley et al., 2009). Finally, cores from the central channel in the middle part of Chesapeake Bay are dominated by laminations, suggesting that macro-infauna have been absent for $\sim 100$ yrs (Schaffner et al., 1992).

Palaeoecologists have devised models for estimating palaeo-oxygenation from the degree of lamination and occurrence of trace fossils (Savrda and Bottjer, 1991). In modern sediments it is recognized that the abundance, body size and diversity of metazoan animals declines at very low oxygen levels (Rhoads and Morse, 1971; Levin, 2003). Thus it is reasonable to assume that the density, size and diversity of animal traces (ichnofacies) in sediments should also decline with increasing hypoxia. A number of ichnofacies 
models have been constructed to relate animal activities and trace morphologies to palaeo-oxygenation (Savrda and Bottjer, 1984, 1987, 1991), based largely on observations from modern hypoxic basins. Reduced density, size, depth of penetration and diversity of macrofaunal traces are documented in oxygen-deficient basins (Rhodes and Morse, 1971; Savrda et al., 1984), fjords (e.g., Nilsson and Rosenberg, 2000) and oxygen minimum zones (Levin, 2003).

However, trends in body size and activity are not always linearly correlated with oxygenation. The occurrence of chemosymbiotic bacterial symbionts within metazoan organisms may pre-adapt them to survive in dysoxic sediments while maintaining large body size or significant burrowing activity. The description of the exaerobic zone includes a shelly fauna comprising large individuals, possibly bivalves or brachiopods (Savrda and Bottjer, 1987). Tubificid oligochaetes in the subfamily Phalodrilidae appear to survive and bioturbate sediments at oxygen levels of $0.02 \mathrm{ml} \mathrm{L}^{-1}$ (= $0.8 \mu \mathrm{M}$ ) (Levin, 2003), possibly with support from symbiotic bacteria that have multiple metabolic functions (Blazjek et al., 2005). These occurrences complicate the interpretation of laminations as they often lead to mixing of sediments under oxygen conditions thought to inhibit bioturbators. Another consideration is that in regions where hypoxia persists over evolutionary time scales, organic matter availability rather than oxygen appears to exert primary control over the development of bioturbating infaunal communities and thus the persistence of laminations. Variations in laminae formation across the Pakistan margin OMZ, and greater formation of laminae on the Pakistan than Oman margins, may be explained better by differences in POC flux than by oxygen levels (Gooday et al., 2009; Levin et al., 2009; Hughes et al., 2009).

\subsection{Chemical and mineral indicators}

\subsubsection{Sulphur and sulphides}

High concentrations of sulphur and sulphide-forming metals in hypoxic and anoxic sediments are the basis of a number of proxies for bottom-water oxygenation (Berner, 1984). In the absence of oxygen, labile organic matter is degraded by prokaryotes utilizing alternative electron acceptors such as nitrate, metal oxides and sulphate, of which the latter is by far the most abundant in marine systems. Sulphate reduction results in the formation of hydrogen sulphide which either reacts with reactive iron minerals or is oxidized chemically and particularly biologically by a diverse community of sulphide oxidizing bacteria. Oxygen limitation restricts the re-oxidation of hydrogen sulphide in sediments underlying hypoxic and anoxic bottom-waters and iron sulphide mineral formation therefore represents the main sink of hydrogen sulphide (Berner, 1994; Middelburg, 1991). Pyrite is

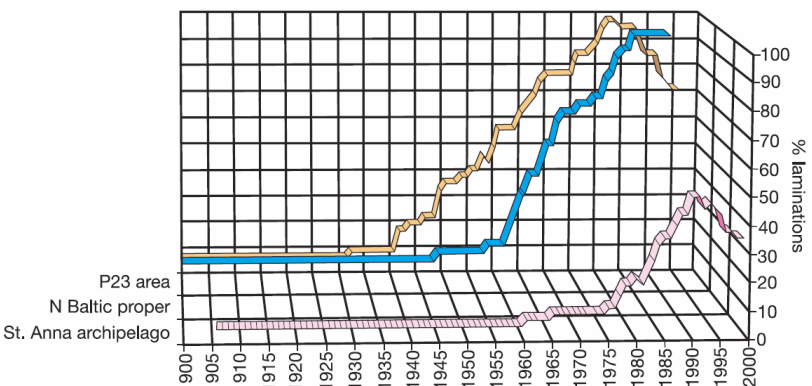

Fig. 8. Laminated sediments in the Baltic Sea. The proportion of laminated sediments in relation to the total number of cores investigated in the St Anna archipelago ( $n=48$ cores), the offshore Baltic proper $(n=35)$ and the P23 area in the NW Baltic proper $(n=40)$. (Redrawn from Marine Pollution Bulletin, Vol. 40, Persson, J. and Jonsson, P.: Historical development of laminated sediments - an approach to detect soft sediment ecosystem changes in the Baltic Sea, 122-124, 2000, with permission from Elsevier.)

normally the dominant iron sulphide mineral formed, but this usually involves acid volatile precursors (AVS, acid volatile sulphides) such as greigite.

One proxy for bottom-water oxygenation is based on the presence or absence of a correlation between organic carbon and reduced sulphur in sediments. In normal marine sediments underlying oxic bottom waters, organic carbon and sulphur are well correlated because a certain carbon delivery relates to a proportional preservation of organic carbon and reduced sulphur (Berner, 1984). In sediments underlying sulphide-rich waters there is also iron sulphide formation occurring in the water column with the result that sediment organic carbon and sulphur contents are unrelated (Berner, 1984; Middelburg, 1991; Passier et al., 1996). The preservation of sulphur has increased in sediments deposited in Chesapeake Bay during recent centuries, together with total organic carbon and total (mainly organic) nitrogen (Cooper and Brush, 1991, 1993) (Fig. 9c). These trends reflect increasing eutrophication and hypoxia and are linked to an increase in the formation of pyrite.

Mineral texture is the basis for another pyrite-related indicator (Wilkins et al., 1996; Passier et al., 1997). The formation of pyrite framboids (aggregations of small grains) apparently requires the presence of limited amounts of oxygen. Their size appears to depend on whether they were formed near the oxic-anoxic interface in the water column and subsequently settled to the seafloor (smaller framboids, $\leq 5 \mu \mathrm{m}$ diameter) or at the oxic-anoxic boundary in the sediment (larger framboids) (Brunner et al., 2006). Moreover, pyrite formed slowly in fully anoxic sediments may be euhedral (Passier et al., 1997). At a coring site northeast of the Mississippi River Delta, the size of the framboids suggested that they were formed mainly in the sediment and that the bottom water had been oxygenated throughout the 20th Century (Brunner et al., 2006). 

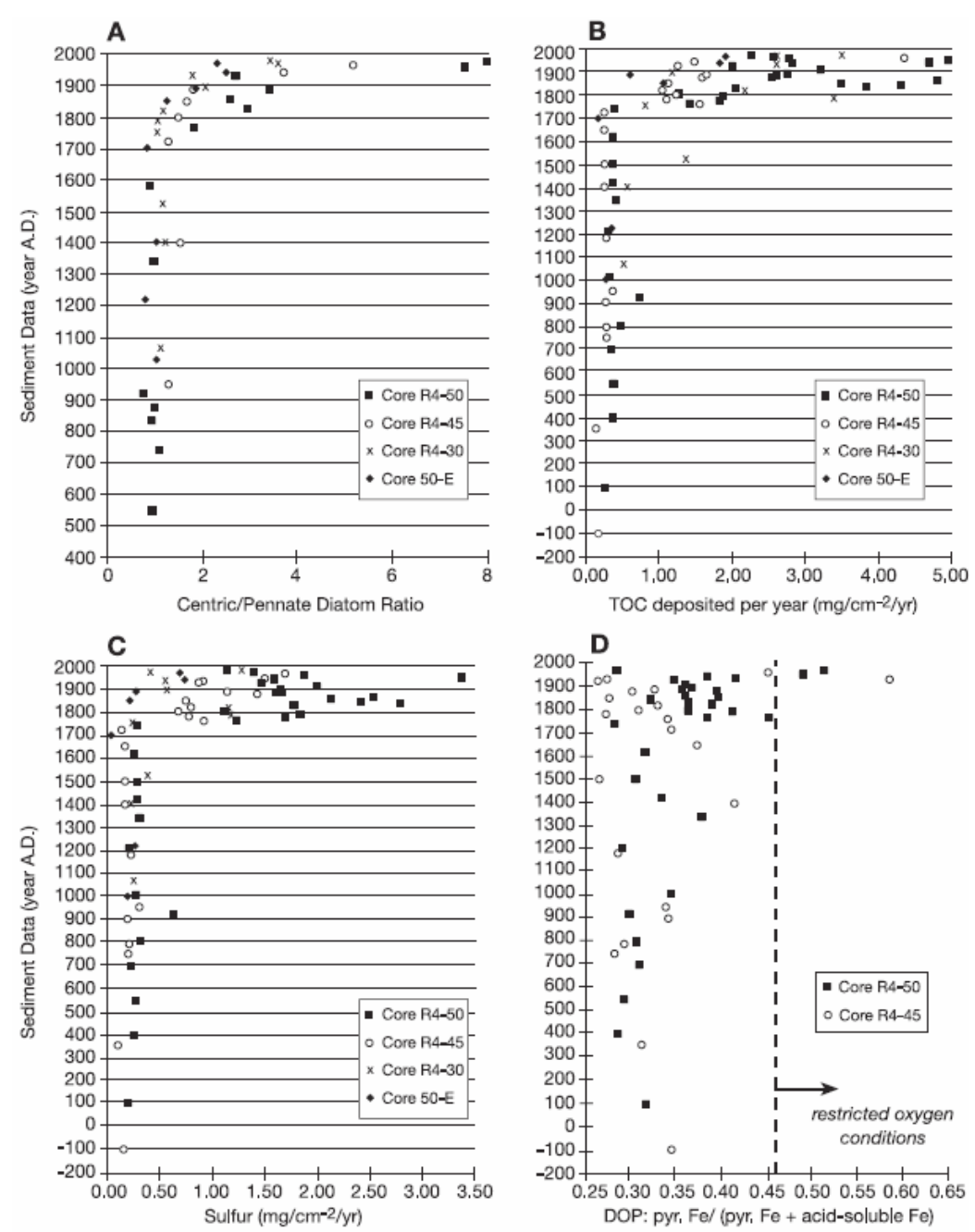

Fig. 9. Long-term sediment records of eutrophication and hypoxia in cores from mesohaline part of Chesapeake Bay. (a) Centric:pennate diatom ratio; increase after 1940 indicate increased eutrophication. (b) Total organic carbon (TOC), (c) Preservation of sulphur, corrected for sedimentation rate. (d) Degree of pyritization (DOP); higher values indicate hypoxic conditions. (Redrawn from Estuaries, Vol. 16, Cooper, S. R. and Brush, G. S.: A 2,500-year history of anoxia and eutrophication in Chesapeake Bay, 617-626, 1993, with permission from Springer.)

Another measure, the ratio between acid volatile sulphides (AVS) and chromium reducible sulphur (CRS), essentially the ratio between sulphur as FeS and sulphur as pyrite, is based on the concept that the conversion of the precursor AVS to CRS (pyrite) requires an oxidant and time (Middelburg, 1991). In a core from Chesapeake Bay, the AVS:CRS ratio increased sharply around 1934 , was stable between 1934 and 1984, and increased again thereafter (Zimmerman and Canuel, 2000, 2002). This trend was coincident with that of biogenic silica, a proxy for planktonic diatom production (see below), and was interpreted as indicating a worsening of anoxic episodes during recent decades. The ratio of AVS to CRS is useful but may give biased information if sediment accumulation rates fluctuate.
Probably the most reliable proxy for historical bottomwater oxygenation is the degree of pyritization (DOP $=$ the ratio of pyritic $\mathrm{Fe}$ to total reactive $\mathrm{Fe}$ ), or its equivalent, the degree of sulfidation (DOS= the ratio of pyritic $\mathrm{Fe}$ and AVS$\mathrm{FE}$ to total reactive $\mathrm{Fe}$ ). This has been used to distinguish between oxic and hypoxic environments in ancient sediments (Raiswell et al., 1988) and is applicable to modern sediments as well (Middelburg et al., 1991; Wijsman et al., 2001a). Cooper and Brush (1991) used this method to trace environmental changes in Chesapeake Bay (Fig. 9d). The degree of pyritization showed a good correspondence with evidence for eutrophication derived from the diversity and composition of diatom assemblages (Cooper and Brush, 1993). 
Finally, sulphur stable isotope ratios have potential as proxies of hypoxic conditions. During sulphate reduction there is significant isotope discrimination so that the hydrogen sulphide formed is strongly depleted in ${ }^{34} \mathrm{~S}$ relative to sulphate. In sediments underlying oxic bottom-waters, a major fraction of the sulphide generated is re-oxidized in multiple steps to sulphate. During this re-oxidation, in particular during the disproportionation reactions, further isotope fractionation takes place. As a consequence, sulphide isotope fractionation increases if sulphate reduction is followed by disproportionation reactions in the presence of oxidants (Canfield and Thamdrup, 1994). Distinct increases in $\delta^{34} \mathrm{~S}$ values in cores from Charlotte Harbor (Florida) seem to reflect an intensification of reducing conditions due to lower bottom-water oxygenation and increased organic inputs to the sediment (Turner et al., 2006). Wijsman et al. (2001b) studied sediments in a zone at the shelf-edge of the Black Sea where oxygen conditions changed with time. They observed high variability in ${ }^{34} \mathrm{~S}$ values of pyrite in sediments and attributed this to fluctuations in the oxygen concentrations of bottom waters or varying sediment accumulation. During oxic periods, sulphide re-oxidation processes became important, resulting in low AVS to CRS ratios and light $\delta^{34} \mathrm{~S}$ values. Anoxic conditions in the bottom waters overlying shelf-edge sediments were reflected in enhanced AVS to CRS ratios and heavier sulphur isotope values.

\subsubsection{Glauconite}

The formation in sediments of the mineral glauconite, a hydrous silicate of potassium, iron, aluminum, or magnesium, is believed to be accelerated under low-oxygen or anoxic conditions in shelf sediments (Bréhéret, 1991; Nelsen et al., 1994). The percentage of glauconite grains in the $>63 \mu \mathrm{m}$ fraction of a core from a hypoxia-influenced site in the Gulf of Mexico increased during the late 1930s and early 1940s. The proportion of hypoxia-tolerant foraminiferans (Nelsen et al., 1994) increased at the same time, suggesting that glauconite may be an indicator of anthropogenically-forced hypoxia.

\subsubsection{Magnetic properties of sediments}

Magnetic minerals provide a powerful tool to determine the dissolved oxygen status of marine sediments. In fully oxic environments, the magnetic characteristics of the mineral assemblage are mostly derived from coarse detrital particles, such as maghemite and magnetite, with a very limited contribution from authigenic and fine-grained ferrimagnetic minerals. Under hypoxic and/or anoxic conditions, however, remagnetization takes place. This results from the precipitation of biogenic or authigenic fine-grained magnetic minerals, e.g. greigite and pyrrhotite (precursors of pyrite), which form as byproducts of microbial metabolism (Robinson and Sahota, 2000; Liu et al., 2004; Larrasoaña et al., 2007). Sulphide minerals such as greigite could indicate the presence of oxygen-depleted bottom water during their formation (see above). These magnetic sulphide minerals are usually ephemeral, however, and thus cannot provide reliable historical records. Moreover, they sometimes develop as a result of late diagenetic processes that occur some metres below the sediment/water interface, and therefore do not reflect the environment in which the sediments were deposited (Lui et al., 2004; Roberts and Weaver, 2005).

Under hypoxic conditions, Fe and Mn oxides, including hematite and magnetite, may be used for respiration by anaerobic bacteria or be consumed by reactions with sulphides. Also, new magnetic minerals may form as a result of $\mathrm{Fe}$ and $\mathrm{Mn}$ cycling,. Consequently, the ratio between different magnetic properties, such as mass-specific magnetic susceptibility $(\chi)$, anhysteretic remanent magnetization (ARM) and saturation isothermal remnant magnetization (SIRM), show distinct contrasts between oxic and anoxic sediments (Robinson and Sahota, 2000). These properties, together with enrichment in some redox-sensitive elements (see below), have been proposed as proxies for poor bottomwater ventilation (i.e. hypoxic conditions) during the formation of Mediterranean sapropels (e.g. Larrasoaña et al., 2003). Rhoads et al. (1991) provide evidence from TEM micrographs of sediments on the Peru shelf that the inventory of biogenic magnetite is associated primarily with dysaerobic oxygen conditions $\left[0.1-0.5 \mathrm{ml} \mathrm{L}^{-1}(=4.3-21.5 \mu \mathrm{M})\right]$ and is 3-5 times lower in aerobic and anaerobic sediments. As far as we are aware, these approaches have not been applied to reconstruction of oxygenation regimes from historical records in coastal settings.

\subsubsection{Trace elements}

Trace elements that are enriched in sediments deposited under hypoxic or anoxic conditions are widely used in palaeoceanography to infer the history of bottom-water oxygenation (Bruland and Lohan, 2003; Calvert and Pedersen, 2007; Tribovillard et al., 2006). The underlying premise is that total trace element concentration can be partitioned into a detrital contribution (often estimated via $\mathrm{Al}$ or by comparison with average shale) and an excess contribution due to hydrothermal, biogenic and authigenic processes. Trace element enrichment of non-hydrothermal sediments can be attributed to either delivery of organic matter and associated biogenic phases $(\mathrm{Ba}, \mathrm{Cd}, \mathrm{Ni}, \mathrm{Zn}, \mathrm{Cu})$ or to diagenetic enrichment due to the redox chemistry of the element involved (e.g. Re, Mo, V, U). Trace elements such as Ba, Cd and Zn show nutrient-type behaviour in the water column and are delivered to sediments with organic matter. They can thus be used as proxies for eutrophication, provided their signal is preserved (Tribovillard et al., 2006). Excess Ba is mainly found in barite (barium sulphate), the preservation potential of which may be low in anoxic sediments with sulphate reduction. $\mathrm{Ni}$ and $\mathrm{Cu}$ are well preserved in anoxic sediments 
because they form sulphides and therefore represent proxies for organic matter abundance, although we are not aware of any application in the historical record.

Trace element such as vanadium, uranium, molybdenum and rhenium have their own redox chemistry and if their reduced form is less soluble than the oxidized form they become enriched in hypoxic and anoxic sediments (Middelburg et al., 1991; Tribovillard et al., 2006). Vanadium, uranium and rhenium are reduced under less reducing conditions (i.e. suboxic) than molybdenum, which requires sulphidic conditions. This differential behaviour provides opportunities to distinguish between suboxic/anoxic and euxinic environments.

Molybdenum is one of the most widely applied trace metals in palaeo-environmental reconstructions. Off Cape Blanc on the northwestern African coast, the $\mathrm{Mo} / \mathrm{Al}$ record showed a perfect correlation with the cumulative percentage of deepinfaunal foraminiferal species, considered to be low-oxygen indicators, over the last 70000 years (Martinez et al., 1999). The sedimentary accumulation of Mo is proportional to sulphide concentrations (i.e., free $\mathrm{H}_{2} \mathrm{~S}$ ). It is regarded as a proxy for water-column anoxia and is not enriched in suboxic sediments that are devoid of sulphide (Crusius et al., 1996). However, the mechanisms by which Mo becomes concentrated in sediments are not fully understood. Under oxic conditions, it is present in the form of $\mathrm{MoO}_{4}^{=}$ion, and can be adsorbed to particulate manganese oxides formed under oxic conditions. These manganese oxides tend to be formed at the oxic/anoxic interface in the water, and can sink into the anoxic zone, carrying molybdenum with them. Once in the suboxic or anoxic zone, the manganese oxides will dissolve, releasing Mo to the water column or porewater (depending on water depth and location of the oxic/anoxic interface). Subsequent fixation in the sediment may involve the formation of organic thiomolybdenates (sulphidic compounds) and inorganic Fe-Mo-S cluster complexes (Adelson et al., 2001). Thus Mo enrichment tends to be associated with the presence of an anoxic water column.

Molybdenum and vanadium have been used occasionally in historical reconstructions (Table 1). Adelson et al. (2001) showed that Mo levels in two cores (55 and PC6) from the upper reaches of the main stem of Chesapeake Bay exhibited considerable variability but were highest in sediments deposited after 1960 (Fig. 10). This was interpreted to indicate increasingly intense seasonal oxygen depletion, consistent with evidence from other sources for rising eutrophication in the mesohaline part of the Bay. This trend was not observed by Zheng et al. (2003) in two cores from an area $\sim 25 \mathrm{~km}$ south of PC6. Instead, they found that Mo levels exhibited variations that were inversely correlated with proxies for palaeosalinity during the 20th Century. They suggested that anoxia had fluctuated naturally as a result of climatically-driven variations in freshwater discharge over time. In a core from the Loiusiana shelf spanning a 1000year period, $\mathrm{V}$ was depleted at levels where peaks in the

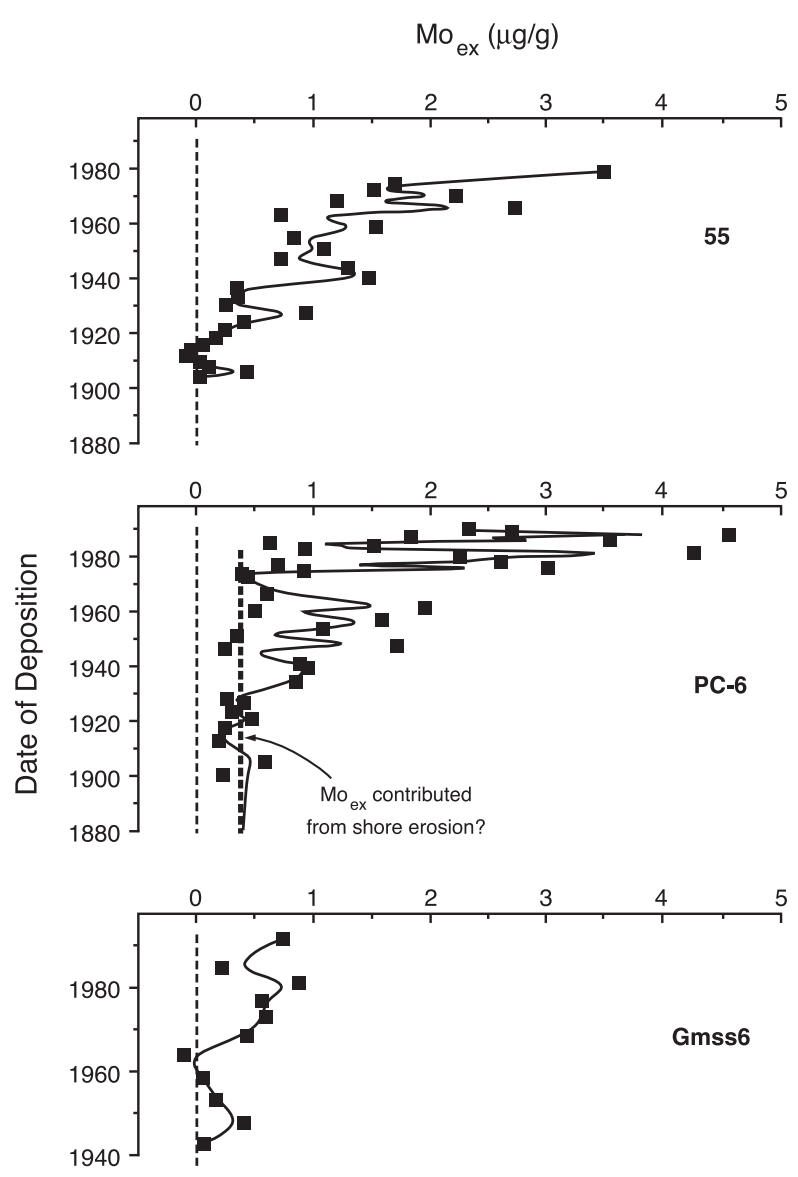

Fig. 10. Excess molybdenum concentration $\left(\mathrm{Mo}_{\mathrm{ex}}\right)$ in three cores from the middle and upper part of Chesapeake Bay. The heavy dotted line in the central panel suggests a baseline input of Mex from shore erosion. The curve shows the gross trends in the data, suggesting increasingly intense seasonal oxygen depletion. (Redrawn from Geochimica et Cosmochimica Acta, Vol. 65, Adelson, J. M., Helz, G. R., and Miller, C. V.: Reconstructing the rise of coastal anoxia: molybdenum in Chesapeake Bay sediments, 237-252, 2001, with permission from Elsevier.)

foraminiferal PEB index indicated hypoxia (Swarzenski et al., 2008). These pre-anthropogenic hypoxic events were probably related to increased discharge from the Mississippi River, caused by climatic fluctuations.

On the western Indian continental shelf, the hypoxia that is formed naturally during late summer and autumn may have intensified in recent years (Naqvi et al., 2000, 2006a) as a result of increased inputs of human-generated nutrients. Here, the $\mathrm{Mo} / \mathrm{Al}$ mass ratio has been found to vary over a narrow range $\left(8.5-11 \times 10^{-4}\right)$ during the last 250 years, as revealed by the analyses of two cores taken from the inner- and midshelf regions off Goa (D'Souza, 2007). The ratio, however, is much higher than the average crustal value of $0.18 \times 10^{-4}$ (Taylor, 1964). This implies prevalence of anoxic conditions in sediments throughout the depositional period. In two 
recent studies on the Indian shelf off Goa, based on three sediment cores from the zone of present seasonal anoxia and covering the last $\sim 200,250$ and 700 years, the V/Al ratio varied between 1 and $14 \times 10^{-4}$ (D'Souza, 2007; Agnihotri et al., 2008). While this range is less than the average crustal value $\left(16.4 \times 10^{-4}\right.$; Taylor, 1964), the highest ratios were generally recorded in the upper portions of the cores (i.e. the last four decades), corresponding to a period of record high productivity. An increase in the $\mathrm{Cu} / \mathrm{Al}$ ratio was also recorded during the same period (Agnihotri et al., 2008).

The trace element chemistry of sediments of Kau Bay (Indonesia), a 470-m deep hypoxic to euxinic basin separated from the Pacific by a shallow sill, has been studied in detail (Middelburg et al., 1989, 1991). These organic-rich sediments underlying hypoxic bottom-waters are enriched in $\mathrm{V}$ and in particular Mo. The Mo and V enrichments showed some well-developed maxima, reflecting periods of stagnant bottom-water conditions (Middelburg et al., 1989) (Fig. 11). These maxima suggested that the frequency of bottom-water ventilation in Kau Bay was related to ENSO events.

\section{Water-column derived indicators of eutrophication and hypoxia}

It should be noted that, while eutrophication often leads to bottom-water hypoxia, this is not always the case. For example, off NW Africa, natural eutrophication caused by upwelling leads to very high levels of primary production, and yet oxygen concentrations in the underlying bottom water remain relatively high (Jorissen et al., 1998).

\subsection{Planktonic indicators of eutrophication and hypoxia}

The main indicators of enhanced primary production linked to eutrophication are diatoms and dinoflagellate cysts. Their remains, and chemical markers derived from them, can be used as indicators of changes in phytoplankton biomass and community composition and hence primary productivity (Rabalais et al., 2004, 2007). Because hypoxia is often associated with eutrophication, we consider these indicators in some detail. The preservation of diatoms and dinoflagellate cysts is also enhanced in oxygen-depleted sediments. Possible multiproxy approaches to distinguishing between enhanced productivity and enhanced preservation are discussed below (5.2).

\subsubsection{Diatoms}

Diatoms are predominantly planktonic, photosynthetic protists in which the cell is encased by a siliceous frustule composed of two valves. They are found in all aquatic environments within the photic zone and generally thrive under eutrophic conditions (Round et al., 1990). Increases in diatom abundance are often an early sign of eutrophication (Smith, 2003). Crosta and Koç (2007) review the use of diatoms

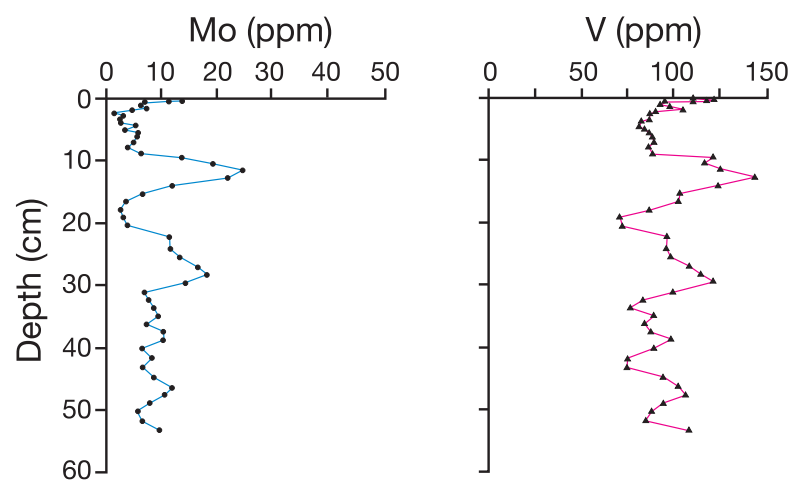

Fig. 11. Mo, V profiles in sediments sampled using a box core (K9B1, 410 m water depth) in Kau Basin, northern Malukum Indonesia. Redrawn from Middelburg PhD thesis, 1990.

as palaeo-indicators. Changes in species composition reflect, among other factors, salinity, sedimentation, turbidity and nutrient availability (Cooper 1995; Rabalais et al., 1996; Parsons et al., 1999, 2006). In the northern Gulf of Mexico, there was a decline in the dominance of heavily silicified diatoms and a corresponding increase in lightly silicified species during the second half of the 20th Century (Rabalais et al., 1996). The rising absolute and relative abundance since the 1950s of Pseudo-nitzschia (Dortch et al., 1997), a lightly silicified diatom that does not preserve well in sediments, has been linked to increased eutrophication combined with silica limitation (Parsons et al., 2002). Although diatom preservation may be enhanced in anoxic sediment with reduced densities of bioturbating animals (McMinn, 1995), this factor does not seem to be responsible for patterns in the diatom record for the northern Gulf of Mexico (Parsons et al., 2002).

In four cores from a part of Chesapeake Bay where anoxic periods are most prevalent and severe, Cooper and Brush (1993) and Cooper (1995) detected a decrease in diatom diversity that began around 1760 and became particularly marked in recent sediments. This resulted from a decline in the ratio of benthic or epiphytic (pennate) species to planktonic (centric) species (Fig. 9a). They attributed these trends to a number of possible factors, including eutrophication linked to increased primary production and anoxia. Similar changes in diatom assemblages, also associated with eutrophication, are reported from the southern Baltic Sea (Andrén, 1999; Andrén et al., 1999) and Laajalahti Bay, Finland (Kauppila et al., 2005).

Qualitative analyses of diatom assemblages cannot be used to reconstruct actual nutrient concentrations, but these can be inferred from transfer functions based on percentage data for modern species (Clarke et al., 2003; Crosta and Koç, 2007). This approach has been used in lakes for some decades (Hall 
and Smol, 1999) and has been applied recently to reconstruct total nitrogen (TN) concentrations in three marine settings, Roskilde Fjord (Denmark), Laajalahti Bay (Finland) (Clarke et al., 2006) and Mariager Fjord (Denmark) (Ellegaard et al., 2006). At the Finnish site, TN values inferred from diatom data track actual monitored values well, except during the most eutrophic periods in the early 1970s when they consistently underestimated total dissolved nitrogen. In Mariager Fjord, the results suggested a progressive increase in $\mathrm{TN}$ since 1900, with reconstructed values being in good agreement with actual TN values between 1985 and 2000 .

Biologically bound silica (BSi) is a useful proxy for diatom production (Turner and Rabalais, 1994). In the Mississippi River Delta Bight and adjacent parts of the continental slope, BSi levels have increased since $\sim 1980$, particularly at depths between 27 and $50 \mathrm{~m}$ where summer hypoxia is most frequent (Turner and Rabalais, 1994; Rabalais et al., 1996; Turner et al., 2004) (Fig. 12). This trend parallels increased nitrogen levels in Mississippi River water discharges. The enhanced seafloor organic loading associated with these diatom fluxes is believed to be responsible for an increase in the persistence and extent of bottom-water hypoxia. A similar trend is evident in cores from Charlotte Harbor estuary (Florida) (Turner et al., 2006). In Chesapeake Bay, trends in the concentration of $\mathrm{BSi}$ in the upper core sections are fairly modest and inconsistent (Cooper, 1995; Cornwell et al., 1996; Colman and Bratton 2003), although Zimmerman and Canuel (2000) show that BSi values increase substantially across a sediment layer corresponding to 1934 and continue to rise thereafter to the top of the core. When BSi values are converted to fluxes (BSi concentrations $\mathrm{x}$ total sediment flux), much clearer trends emerge, with a 4-5-fold increase beginning 200-250 years ago (Colman and Bratton, 2003). A sharp increase in BSi flux after $\sim 1770$ is likewise evident in a core from New Bedford Harbor, Massachussetts (Chmura et al., 2004).

Several factors complicate the relationship between BSi and diatom production (Colman and Bratton, 2003), particularly in turbid coastal environments (e.g. off large river estuaries) where biogenic silica from terrestrial sources such as phytoliths can be an important source for BSi. In the case of the Mississippi River Delta Bight, however, most terrestrial material flows off the shelf or becomes entrained in the Louisiana Coastal Current so that carbon flux in the area of hypoxia is from in situ diatom production, as indicated by stable carbon isotope ratios (Turner and Rabalais, 1994). The determination of BSi in marine sediment is also subject to considerable controversy and is affected, for example, by the leaching of non-biological silica from clay minerals (Lui et al., 2002). Correction using the $\mathrm{Al} / \mathrm{Si}$ ratio and/or other chemical leaching methods may lead to either an overestimate or underestimate of $\mathrm{BiS}$ values.
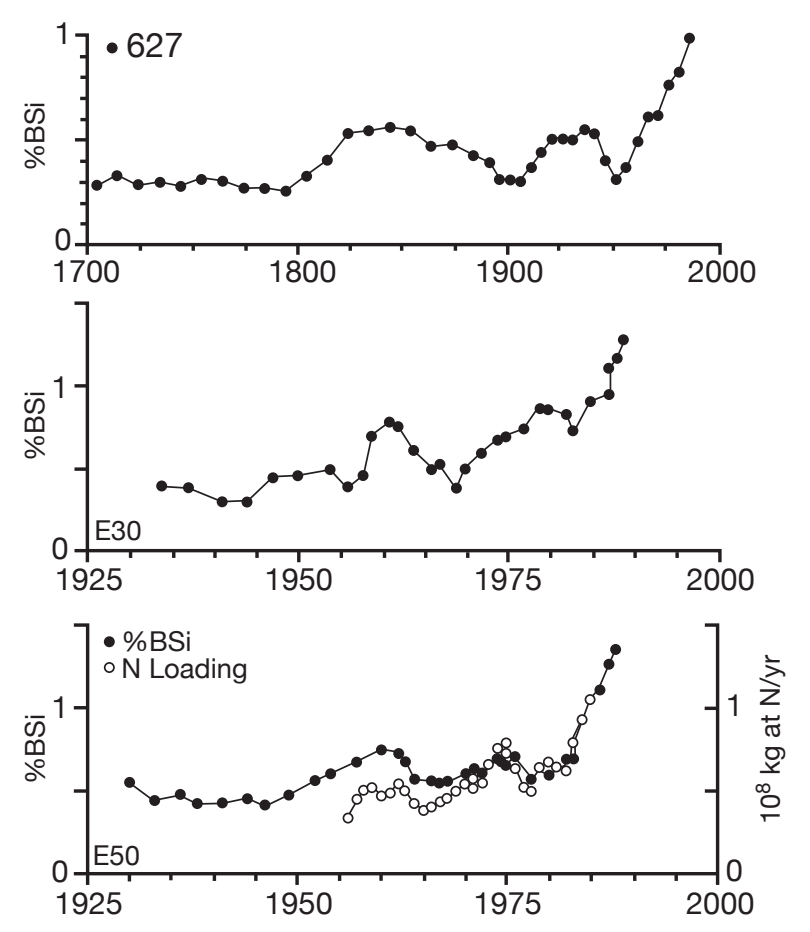

Fig. 12. Average concentrations of biologically bound silica (BSi) in sediment profiles of three dated sediment cores taken at 27-50-m water depth in the Louisiana inner continental shelf, SW of the Mississippi River delta. A 3-yr running average is plotted against time determined by $\mathrm{Pb} 210$ dating. For Station E50, a 3-yr average nitrogen loading from the Mississippi River is superimposed on the BSi trend. (Reprinted with permission from Macmillan Publishers Ltd (Nature), Turner, R. E. and Rabalais, N. N.: Coastal eutrophication near the Mississippi river delta, Nature, 368, 619-621, 1994)

\subsubsection{Dinoflagellate cysts}

Dinoflagellates are autotrophic, heterotrophic, or mixotrophic protists found mainly in marine and brackish but also in freshwater settings (de Vernal et al., 2006). About 10-20\% of the 2000 known species produce acid-resistant resting cysts, typically $15-100 \mu \mathrm{m}$ diameter, which sink to the seafloor and can remain viable in bottom sediments for many years (Dale, 1996; de Vernal and Marret, 2007). These "dinocysts" are preserved in ancient sediments, mainly those deposited in coastal waters (Dale and Dale, 2002). Unlike calcareous microfossils, dinocysts are organic in composition and therefore resistant to dissolution. Being derived from planktonic organisms, they reflect surface-water parameters such as temperature, salinity, sea-ice cover and surface primary productivity and forms of nitrogen (such as nitrate versus ammonium), rather than conditions on the seafloor (Dale, 1996; Radi et al., 2007, 2008). However, some species, many of them heterotrophic, are characteristic of eutrophic conditions, both natural and anthropogenic, and thus may be associated with seafloor hypoxia (Willard 
et al., 2003). Thorsen and Dale (1997) suggested that an increased proportion of heterotrophic cysts can be used as an indicator of eutrophication. Most reconstructions of surface productivity based on dinocyst assemblages are qualitative, but transfer functions that yield reasonably accurate $( \pm 15 \%)$ estimates of productivity have recently been developed (Radi et al., 2008).

Dinoflagellate cysts have been used as indicators of environmental change in Holocene and Quaternary sequences (de Vernal et al., 2006; de Vernal and Marret, 2007), including recent historical periods (Dale and Dale, 2002). Dale et al. (1999) and Dale (2000) described changes in dinoflagellate assemblages in the inner part of Oslofjord over a $>500 \mathrm{yr}$ interval. The record clearly reflected the onset and development of eutrophication during the late 19th and early 20th Century, its peak in the 1940s and 1950s, and recovery of the system following remediation efforts in the 1970s and 1980s. One particular species, Lingulodinium machaerophorum (the cyst of the autotrophic species Gonyaulax polyedra), was strongly associated with eutrophic conditions and led to an overall two-fold increase in cyst abundance. In a similar study in Frierfjord, Dale (2000) recognised a number of phases over a 300-year core record that could be interpreted either in terms of pollution or eutrophication, although the signal was less clear than in the Oslofjord. Based on dinocysts, Sangiorgi and Donders (2004) distinguished between the lower part of a core from the northern Adriatic Sea, representing the period between 1830 and 1924, and the upper part (1930-1989) during which there was a progressive increase in the heterotrophic/autotrophic ratio as well as the abundance of L. machaerophorum. Since $\sim 1930$, there has been an increase in eutrophication together with incidences of severe bottom-water hypoxia in the northern Adriatic Sea (Justić et al., 1987; Justić, 1991). Changes in dinocyst assemblages in Mariager Fjord (Denmark) during the last century are similarly consistent with increased eutrophication (Ellegaard et al., 2006).

Dinocysts have also been used to trace anthropogenic eutrophication in Japanese and North American estuaries. Although there was no overall increase in cyst abundance, a core from Yokohama Port, Japan, revealed a clear shift around the 1970 level from an assemblage dominated by autotrophic dinoflagellate cysts to one dominated by the cysts of heterotrophs (Matsuoka, 1999). This coincided with the beginning of strong economic growth in Japan and probably reflected the onset of eutrophication. The first North American study was carried out by Pospelova et al. (2002) in New Bedford Harbor and Apponagansett Bay, Massachusetts, both shallow, unstratified estuaries not subject to severe hypoxia. Here, there was also no overall increase in the concentration of cysts during the last 500 years but there was much greater variability in their abundance during the 20th Century compared to earlier periods. At the same time, a sharp decrease in species richness was observed in New Bedford Harbor, the more strongly polluted locality. These trends are be- lieved to reflect increased environmental stress arising from eutrophication and heavy metal inputs. A later comparison of dinocyst assemblages with two other palaeoproductivity proxies, pigments and $\mathrm{BSi}$, revealed a succession of changes in the New Bedford Harbor ecosystem over the past few hundred years linked to forest clearance, sewage discharges, and harbour modifications (Chmura et al., 2004). Unlike Dale et al. (1999) and Sangiorgi and Donders (2004), both Matsuoka (1999) and Pospelova et al. (2002) recorded decreases in the abundance of Lingulodinium machaerophorum in response to eutrophication. Pospelova et al. (2002) suggest that this autotrophic species may increase as a response to oxygen depletion rather than to eutrophication. Thibodeau et al. (2006) report two- to three-fold increases in the concentration and accumulation rates of dinocysts in the upper parts of two cores from the St Lawrence Estuary. These were probably caused by increased primary production, and possibly eutrophication, since about 1960.

Dinocysts may reflect water column oxygen concentrations as well as surface primary productivity. Willard et al. (2003) used pollen and dinocysts as proxies for regional precipitation, estuarine salinity and dissolved oxygen in Chesapeake Bay during the past 2500 years. Based on quantitative analyses of dinocyst assemblages, they identified a period between 1400 and 1500 AD characterised by a major change in species composition (Fig. 13). They interpreted this as indicating oxygen depletion in the deep channel of Chesapeake Bay and estimated minimum annual mean concentrations at $0.5-1.0 \mathrm{mg} \mathrm{L}^{-1}\left[0.36-0.72 \mathrm{ml} \mathrm{L}^{-1}(=15.6-\right.$ $31.2 \mu \mathrm{M})$ ]. An important consideration in the interpretation of dinocyst records is the possibility of enhanced preservation in anoxic sediments. For example, heterotrophic species of Protoperidinium, which are strongly associated with high productivity, are easily degraded in the presence of oxygen but occur in large numbers in sediments deposited under anoxic or hypoxic conditions (Zonneveld et al., 1997; Versteegh and Zonneveld, 2002). Enhanced preservation in anoxic sediments extends to other organic remains, including the fish scales that are abundant in some sapropel deposits (Jorissen, unpublished observations).

\subsection{Sediment chemistry}

\subsubsection{Organic $\mathrm{C}, \mathrm{N}$ and their stable isotopes}

Areas prone to hypoxia typically exhibit an upcore increase in the accumulation of total sedimentary organic carbon (TOC). Such trends could reflect the fact that labile components in younger sediments have had less time to decompose, an increase in water column productivity, an increase in the supply of allochthonous organic matter, an intensification of oxygen depletion, or a combination of these factors (Cornwell et al., 1996; Zimmerman and Canuel, 2002). Particular 

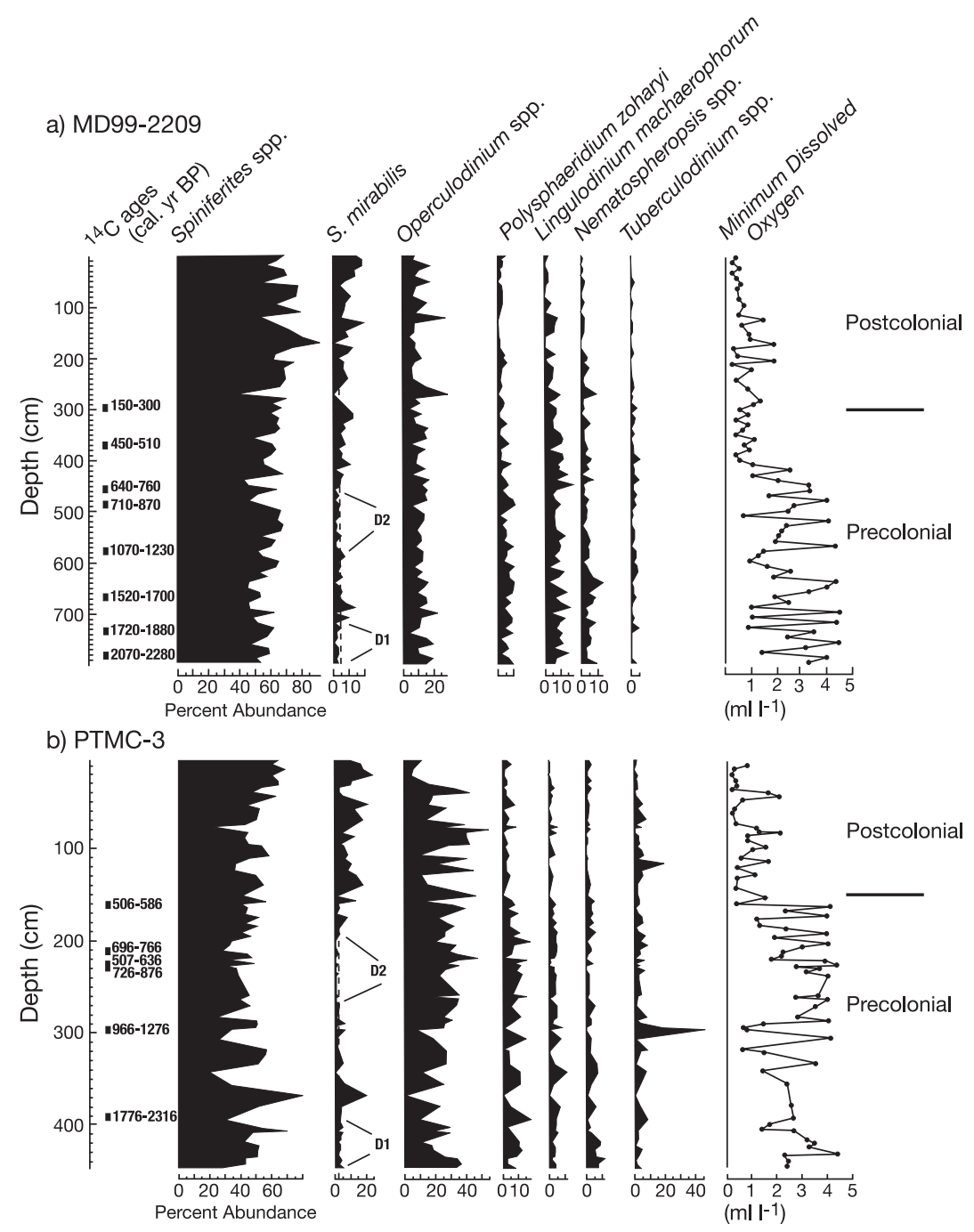

Fig. 13. Percentage abundance of dinoflagellate cyst taxa in two cores from the mesohaline part of Chesapeake Bay. Estimates of minimum annual dissolved oxygen are calculated from minimum DO values for 10 closest modern analogues. (a) Core MD99-2209, near mouth of Rhode River. (b) Core 1071 PTMC-3, near mouth of Potomac River. (Redrawn from Holocene, Vol. 13, Willard, D. A., Cronin, T. M. and Verado, S.: Late-Holocene climate and ecosystem history from Chesapeake Bay sediment cores, USA, 201-214, 2003, with permission from SAGE Publications.)

debate has centred around the extent to which increases in TOC reflect increased organic flux or enhanced preservation (e.g. Cowie, 2005 and references therein).

Studies of historical records have usually linked increases in TOC to increased phytplankton production. In Bunnefjord (the innermost part of the Oslofjord), TOC concentrations were highest in sediment layers corresponding to the period (1945-1982) of most intense anthropogenic eutrophication (Pinturier-Geiss et al., 2002). Along the west coast of India off Goa, large upcore increases in TOC and TN observed in the sediments of the inner- and mid-shelf since $\sim 1950$ have been attributed to enhanced biological production fuelled by a combination of intensified summer monsoon-driven upwelling and a greater runoff of nutrients from land (D'Souza, 2007; Agnihotri et al., 2008; Kurian et al., 2009). Similar in- creases in organic carbon accumulation rates in cores from the southern Baltic Sea are likewise believed to reflect increased input of organic carbon resulting from eutrophication (Andrén, 1999; Andrén et al., 1999; Struck et al., 2000). However, although eutrophication is usually considered to be the main driver of upcore TOC increases, it is often associated with bottom-water hypoxia. In Chesapeake Bay, the TOC content of the sediment has increased over the last 200 years, with abrupt increases at certain horizons (1880-1915, 1945), probably due to enhanced productivity (Zimmerman and Canuel, 2002). TN also increased upcore in Chesapeake Bay sediments and was linearly correlated with TOC values (Cooper and Brush, 1991; Bratton et al., 2003). At the same time, other indicators (DOP and AVS/CRS, see above) suggested that hypoxia/anoxia had increased, coincident with 
eutrophication (Cooper and Brush, 1993; Zimmerman and Canuel, 2002). In Charlotte Harbor (Florida), Turner et al. (2006) interpreted a post-1950 rise in sediment organic carbon content in cores to indicate an increased input from phytoplankton production. Based on a multiproxy approach, they also concluded that the increased organic matter loading was responsible for an expansion in the area impacted by hypoxia.

Stable isotopes of carbon and nitrogen can yield important insights into the sources and processing of organic matter preserved in sediments. In historical records from coastal settings, the stable carbon isotope signal is usually interpreted in terms of the relative contribution of terrestrial versus marine carbon sources. Thus, trends in $\delta^{13} \mathrm{C}$ over a 2700 -year period in Chesapeake Bay are believed mainly to reflect changes in the relative importance of estuarine productivity and terrestrial material delivered to the Bay, which are related ultimately to climatic fluctuations (Bratton et al., 2003). Voss and Struck (1997) considered increases in $\delta^{13} \mathrm{C}$ in the Baltic cores over the last 100 years to be caused by organic enrichment linked to increased eutrophication and primary productivity in the marine environment and the rivers discharging into it. Ellegaard et al. (2006) reached a similar conclusion based on a core from Mariager Fjord (Denmark). C-isotopebased approaches have also been applied in the Gulf of Mexico (Eadie et al., 1994; Turner et al., 2006) and New Bedford Harbor, Massachussetts (Chmura et al., 2004) with increases of marine-source carbon in more recent years consistent with eutrophication (Fig. 14). However, over the western Indian shelf, where the organic matter is largely of marine origin, no major change in $\delta^{13} \mathrm{C}_{\text {org }}$ appears to have occurred during the last 1300 years (Agnihotri et al., 2008).

Stable nitrogen isotope ratios $\left({ }^{15} \mathrm{~N} /{ }^{14} \mathrm{~N}\right.$; i.e. $\left.\delta^{15} \mathrm{~N}\right)$ have been widely used as indicators of anthropogenic eutrophication in aquatic ecosystems (Voss et al., 2000; Cole et al., 2004). Compared to carbon isotopes, differences between the $\delta^{15} \mathrm{~N}$ values of the terrestrial and marine-derived material are small, with the former characterized by slightly lower ratios (Wada and Hattori, 1991). However, riverine and terrestrial nitrogen is intensively processed at the landocean interface with the consequence that dissolved and particulate $\delta^{15} \mathrm{~N}$ become rather heavy (e.g. Middelburg and Herman, 2007). These heavy ${ }^{15} \mathrm{~N}$ values are transferred up the food chain and have been used to assess the anthropogenic $\mathrm{N}$ loadings in coastal settings (e.g. McClelland and Valiela, 1998). The isotopic composition of fixed N (mostly nitrate) in the ocean is determined by its cycling within the water column and sediments (Brandes and Devol, 2002). Enrichment in ${ }^{15} \mathrm{~N}$ in organic matter can arise either from partial nitrate utilization (Altabet and Francois, 1994) or uptake of isotopically heavy $\mathrm{NO}_{3}^{-}$linked to water column denitrification (i.e. preferential loss of ${ }^{14} \mathrm{NO}_{3}^{-}$) (Brandes et al., 1998; Brandes and Devol, 2002; Bratton et al. 2003). Photosynthesis involving nitrogen originating from denitrification can produce a particularly strong signal, with $\delta^{15} \mathrm{~N}$ values $>94$,

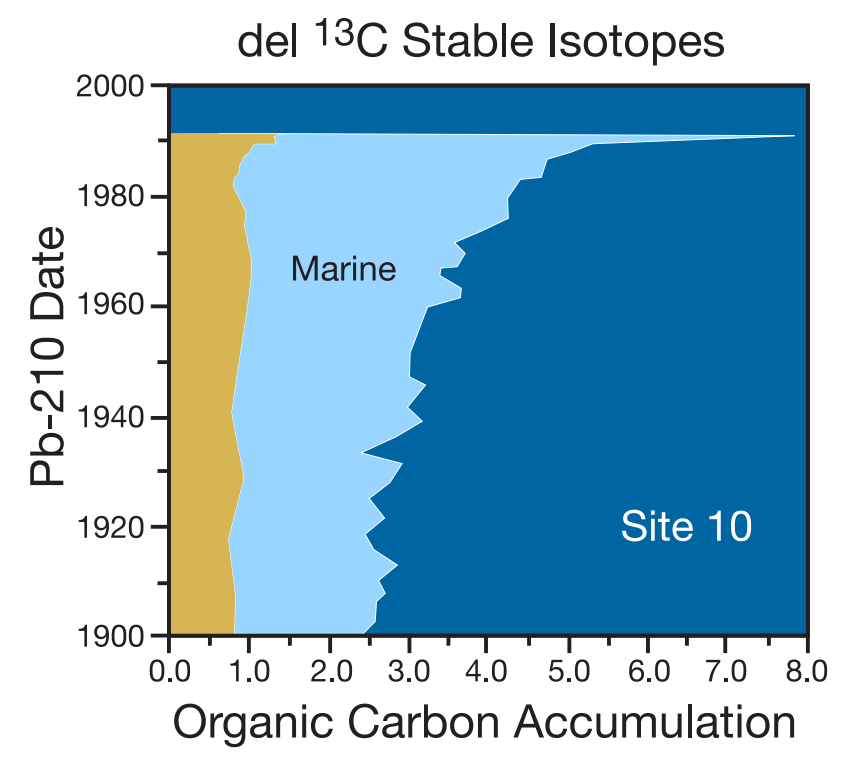

Fig. 14. Organic carbon accumulation rate $\left(\mathrm{Ccm}^{2} \mathrm{yr}^{-1}\right)$ in a box core obtained at Station 10 (29-m water depth) in a chronically hypoxic area on the Louisiana inner continental shelf, SW of the Mississippi Delta. The partitioning of organic matter into a terrestrial (yellow) and marine (blue) component is based on $\delta^{13} \mathrm{C}$ data. (From Estuaries, Vol. 17, Eadie, B. J., McKee, B. A., Lansing, M. B., Robbins, J. A., Metz, S., Trefry, J. H., Records of nutrient-enhanced coastal productivity in sediments from the Louisiana continental shelf, 754-765, 1994, with permission from Springer.)

much higher than those generated in oxic settings (Hendy and Pedersen, 2006). Accordingly, eutrophication with extensive nitrogen recycling of external nitrogen and hypoxia with water-column denitrification may be associated with heavier $\delta^{15} \mathrm{~N}$ values for sedimentary organic matter. Bratton et al. (2003) attributed the trend towards heavier $\delta^{15} \mathrm{~N}$ values since about the end of the 18th Century in Chesapeake Bay cores mainly to this mechanism. The upturn coincided with the onset of land clearance by colonists, which would have increased erosion and nutrient input to the Bay. Fluctuations superimposed on this overall trend were probably caused by climatic oscillations (wet-dry cycles). Eadie et al. (1994), Kappila et al. (2005) and Ellegaard et al. (2006) also suggest denitrification as a possible contributor to increased sediment $\delta^{15} \mathrm{~N}$ measured in core profiles. Rises in total organic nitrogen and $\delta^{15} \mathrm{~N}$ values in cores from the Baltic (Voss and Struck, 1997; Voss et al., 2000; Struck et al., 2000) and Laajalahti Bay, Finland (Kappila et al., 2005) are believed to reflect eutrophication caused by riverine inputs of land-derived nitrate enriched in ${ }^{15} \mathrm{~N}$.

Elevated $\delta^{15} \mathrm{~N}$ values do not necessarily occur in all coastal hypoxic zones. In the intensely denitrifying waters of the Indian shelf, Naqvi et al. (2006b) found relatively modest enrichment of ${ }^{15} \mathrm{~N}$, corresponding to a fractionation factor $(\varepsilon)$ of 7.2-7.7, compared to values of 25-30 in the openocean denitrification zones (Brandes et al., 1998). Consistent 
with this apparently lower fractionation factor, Agnihotri et al. (2008) reported an average $\delta^{15} \mathrm{~N}$ of only 6.6 for the upper $5 \mathrm{~cm}$ in a sediment core extending back to $\sim 1300 \mathrm{AD}$ (Fig. 15). In fact, sedimentary $\delta^{15} \mathrm{~N}$ at this location appears to have decreased slightly but steadily over the last 150-200 years, whereas productivity proxies suggest an increase in productivity over the same period (Kurian et al., 2009). During the Maunder Minimum of the Little Ice Age, however, the $\delta^{15} \mathrm{~N}$ value fell to $\sim 6 \%$, probably caused by a decrease in productivity. Overall, the isotope data from the Indian shelf casts doubts over the universal applicability of $\delta^{15} \mathrm{~N}$ as a robust denitrification proxy.

\subsubsection{Biochemical indicators: pigments and lipid biomarkers}

Sediment cores yield pigments derived from phytoplankton, mainly diatoms but also dinoflagellates and cyanobacteria, which can be analysed by high performance liquid chromatography (HPLC). Chlorophyll and its degradation products (phaeopigments) reflect overall phytoplankton biomass, while carotenoid pigments serve as biomarkers (molecular fossils) for particular phytoplankton taxa, e.g. fucoxanthin for diatoms and prymnesiophytes (Wright and Jeffrey, 1987) and zeaxanthin for cyanobacteria (Guillard et al., 1985). However, the differential preservation of pigments, discussed below, means that changes in their concentrations over time cannot be translated directly into phytoplankton community composition.

In the Gulf of Mexico, upcore increases in chlorophyll a and phaeopigments were gradual from 1955 to 1970 and then more rapid to the late 1990s (Rabalais et al., 2004). Zeaxanthin shows similar pattern, indicating that cyanobacteria were not a major biomass component of phytoplankton prior to 1950s. The increase in chloropigments was most evident in areas that are presently most prone to hypoxia, indicating either a sharp increase in eutrophication, or hypoxia, or both these phenomena, in the latter part of the 20th Century. Cores from Charlotte Harbor showed similar pigment increases as well as BSi increases since 1950 (Turner et al., 2006). Peaks in chlorophyll $a$, its breakdown products and diatoxanthin, corresponding to high nutrient loads, were reported from Laajalahti Bay (Kauppila et al., 2005).

Lipid biomarkers (sterols, fatty acids, fatty alcohols) preserved in sediments are powerful tools for tracing environmental changes (Ficken and Farrimond, 1995; Zimmerman and Canuel, 2000, 2002; Smittenberg et al., 2004, 2005). Marine organisms, including bacteria, diatoms and dinoflagellates, produce characteristic lipid biomarkers that track changes in plankton communities in response to eutrophication. In a core from Chesapeake Bay, biomarkers derived from phytoplankton and microbial sources consistently increased in concentration above the 1934 horizon (Zimmerman and Canuel, 2000). This two- to ten-fold increase was interpreted as being depositional in origin and due to in- creased production of plankton and microbially derived organic matter. It was concurrent with increases in biogenic silica, a proxy for diatom production. Two other cores from Chesapeake Bay also exhibited increases in lipid concentrations during the 20th Century, although the precise patterns were different (Zimmerman and Canuel, 2002). Shifts in the ratios of biomarkers for different phytoplankton taxa revealed changes in plankton composition, for example, an increase in the abundance of dinoflagellates relative to diatoms after 1915 (Zimmerman and Canuel, 2002). In Kyllaren Fjord, a euxinic Norwegian fjord, there has been a substantial increase in the accumulation of biomarkers characteristic of marine planktonic organisms, presumably linked to eutrophication resulting either from natural processes or human activities (Smittenberg et al., 2004). Sterol records, particularly for dinosterol, preserved in a core from the Indian coast (the same one analysed by Agnihotri et al., 2008), closely resembled records for total solar irradiance, suggesting insolation control of upwelling-driven productivity (Kurian et al., 2009). Data for sterols and other productivity indicators ( $\mathrm{OC}$ and $\mathrm{TN}$ ), indicate that the productivity in the last few decades has been the highest seen during the last 700 years. Interestingly, while the phytol content appears to have declined recently, that of dinosterol continues to rise, possibly due to a shift in phytoplankton composition in response to eutrophication.

In the context of this review, green pigmented sulphur bacteria (Chlorobiaceae) are of particular interest as biomarker sources since they are associated with sulphidic/anoxic conditions rather than with eutrophication. These strictly anaerobic organisms require light and $\mathrm{H}_{2} \mathrm{~S}$ and synthesise two characteristic pigments, bacteriochlorophylls and isorenieratene. Farnesol, the esterifying alcohol of the Chlorobium chlorophylls, has been found in the sediments of the euxinic Kau Bay (Middelburg et al., 1994). Isorenieratene and its derivatives are preserved in sediments dating back to the Ordovician (Koopmans et al., 1996). Their occurrence in some eastern Mediterranean sapropels of Pliocene age has been used to infer the existence of sulphidic/anoxic conditions in the photic zone of the water column (Passier et al., 1999; Menzel et al., 2002). The sedimentary record of isorenieratene in Black Sea sediments has been used to argue that the photosynthethic green sulphur bacteria have been active in the Black Sea for the last 6200 years and that penetration of the photic zone by anaerobic waters is a natural phenomenon (Sinninghe Damsté et al., 1993). In shallow water, where light penetrates to the seafloor, green pigmented sulphur bacteria may also colonise the sediment. Chen et al. (2001) used bacteriochlorophyll-e and its breakdown products derived from two species of green sulphur bacteria (Chlorobium phaeovibroides and C. phaeobacteroides) to trace the development of photic-zone hypoxia on the Louisiana shelf over a 100-yr period (Fig. 16). Although these anaerobic prokaryotes require light, they can survive where light levels are very low and so it is unclear whether 


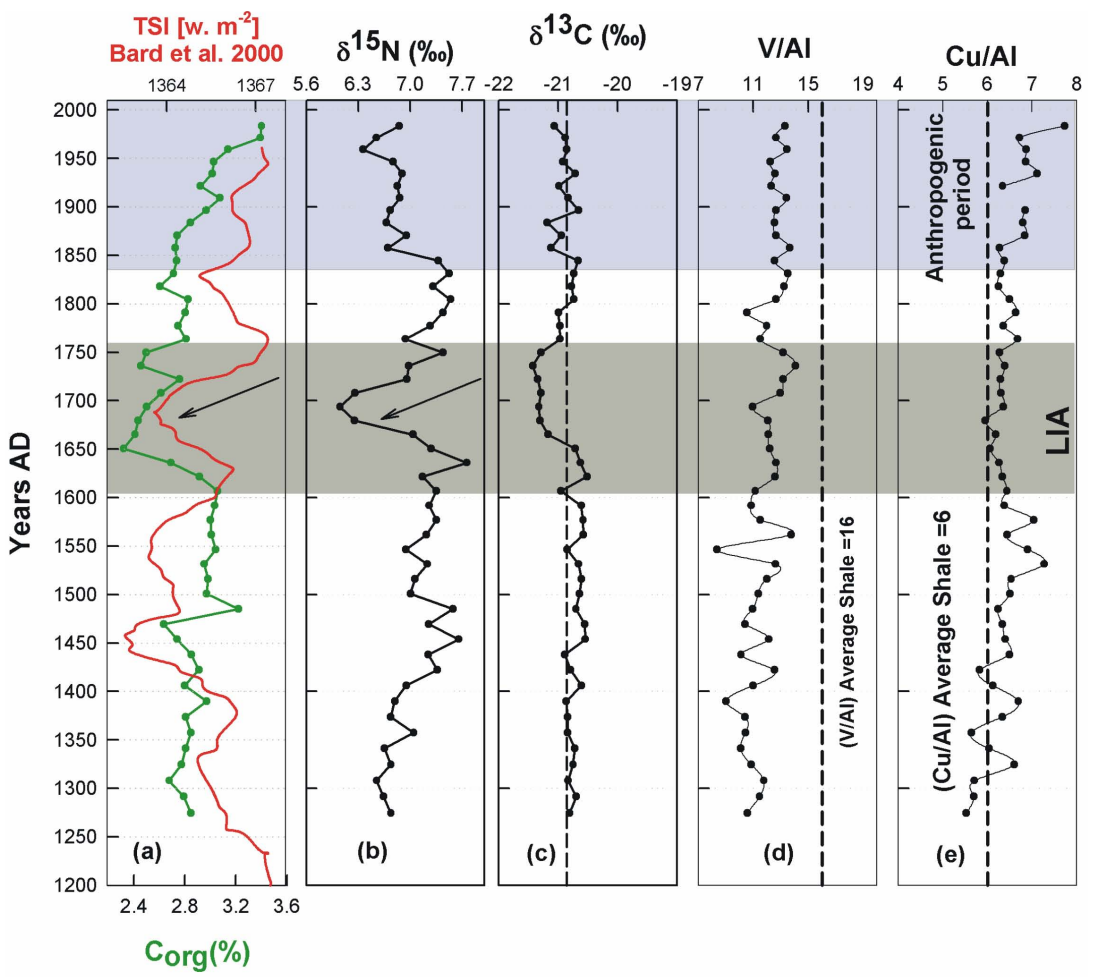

Fig. 15. Profiles of selected productivity and redox proxies in the Gravity Core CR-2 from the inner shelf region off Goa (Lat. $14.80^{\circ} \mathrm{N}$, Long. $74.20^{\circ} \mathrm{E}$; water depth $\sim 45 \mathrm{~m}$ ) in the eastern Arabian Sea. (a) Total solar irradiance (TSI) from Bard et al. (2000) and organic carbon (Corg), (b) $15 \mathrm{~N}$ of sedimentary organic matter, (c) ${ }^{13} \mathrm{C}$ of Corg, (d) V/Al and (e) $\mathrm{Cu} / \mathrm{Al}$. The core was dated by $\mathrm{C}-14$ and $\mathrm{Pb}-210 \mathrm{techniques}$. The arrows within the grey portion point to the Maunder Minimum of the Little Ice Age (LIA) whereas the upper portion of the core corresponding to the Anthropocene period is shown in purple (modified from Agnihotri et al., 2008).

they were living at the sediment-water interface or in the overlying water column. Nevertheless, Chen et al. (2001) regard these pigments as the "first direct and unbiased indicators" of bottom-water hypoxia (as opposed to sediment anoxia) on the Lousiana shelf. Trends in the bacterial pigment data were the same as those for other indicators of eutrophication and hypoxia (Rabalais et al., 2007). In a sediment core from Kyllaren Fjord, isorenieratene and okenone (the latter derived from purple sulphur bacteria) indicated that anoxic conditions had persisted throughout the 400-yr record (Smittenberg et al., 2004).

It should be noted that the microbial decomposition of organic matter, including biomarkers, operates at different rates in oxic and hypoxia settings. In the Arabian Sea, the accumulation and preservation of different biomarkers can vary by a factor up to 10 between severely hypoxic $\left[\mathrm{O}_{2}=0.05 \mathrm{ml} \mathrm{L}^{-1}(=2.2 \mu \mathrm{M})\right]$ and oxic sediments (Sinninghe Damsté et al., 2002). Niggemann and Schubert (2006) showed that concentrations of total fatty acids in sediments from the core of the OMZ off central Chile $\left(\mathrm{O}_{2}=0.01 \mathrm{ml} \mathrm{L}^{-1}\right)$ were three to four times higher than in sediments from below the OMZ. This suggested enhanced preservation of these compounds in hypoxic environments, although the shallower water depth in the OMZ, and hence less efficient water column degradation, may also have been a factor (Niggemann and Schubert, 2006). The sensitivities of biomarkers to oxic decomposition also vary, and their accumulation rates therefore depend strongly on exposure to well-oxygenated conditions. For example, the carotenoid fucoxanthin, biphytane diols and dinosterol/dinostanol are all degraded to a greater extent than other marine biomarkers such as the alkenones and long-chain diol/keto-ols (Sinninghe Damsté et al., 2002). Concentrations of phytol and dinosterol are higher (six and two times, respectively) in the Arabian Sea oxygen minimum zone (OMZ) core, where the bottom water is severely hypoxic, than outside the OMZ (Schulte et al., 2000). Lycopane, a biomarker probably derived from phytoplankton, also exhibits enhanced preservation in sediments deposited in the core regions of the Arabian Sea and Peru OMZs. This observation led Sinninghe Damsté et al. (2003) to propose the ratio between lycopane and terrestrial $\mathrm{C}_{31} n$-alkane as an oxygenation proxy in ancient marine sediments.

\subsection{Indirect indicators}

Although changing oxygenation regimes are often linked to productivity, they can also be forced indirectly by additional factors for which we have proxies. For example, in 
coastal embayments such as Chesapeake Bay, hypoxia development may be closely linked to stratification, which in turn can be induced by increased precipitation and freshwater input (Cronin et al., 2000; Hagy et al., 2004). Precipitation may also exacerbate nutrient enrichments resulting from fertilizer use, and often will fluctuate considerably on multidecadal time scales. Historical records of salinity variability can reflect precipitation changes. Oxygen isotopes $\left(\delta^{18} \mathrm{O}\right)$ of foraminiferal tests are often used to estimate salinity in sediments and provide precipitation reconstructions for Chesapeake Bay (Saenger et al., 2006). Land use also profoundly influences vegetation, hydrologic pathways and patterns, nutrient runoff, and precipitation, with important consequences for eutrophication and hypoxia. Proxies for land use may include pollen shifts and salinity indicators as well as the other proxies discussed above (Willard and Cronin, 2007).

\subsection{Multiproxy approaches}

The experience of palaeoceanographers suggests that different proxies often yield inconsistent results. The use of several proxies in combination usually provides more convincing reconstructions of past oceans than single indicators (Guiot and de Vernal, 2007; Tribovillard et al., 2006). Multiproxy approaches are being used increasingly in historical studies. One example is the study of Turner et al. (2006) in Charlotte Harbor estuary (Florida). They utilized a suite of biological and geochemical proxies, including TN, TOC, C:N, $\mathrm{P}$, trace metals, stable isotopes ( $\mathrm{S}, \mathrm{N}, \mathrm{C})$, biogenic silica and phytoplankton pigments (Chl a, caretonoids), to reconstruct conditions in the estuary between 1800 and 2000. Together, these suggested that phytoplankton production had increased in response to increased nitrogen inputs, leading to an expansion of the area impacted by hypoxia. This study influenced water resource management policy, helping to convince the local management agency of the need to control nutrient inputs into the estuary. Rabalais et al. (2007) presented a synthesis of previous studies in the northern Gulf of Mexico that used a range of indicators for eutrophication (diatoms and biogenic silica, organic carbon of marine origin, phytoplankton pigments) and hypoxia (the mineral glauconite, bacterial pigments, faunal indices) (Fig. 6). Their conclusions were similar to those of Turner et al. (2006); phytoplankton production has increased sharply during the 20th Century, leading to severe or persistent hypoxia which began in the 1960s and became most pronounced in the 1990s.

\section{Discussion}

\subsection{Historical reconstructions as part of palaeoceanography}

Reconstructions of environmental changes caused by human activities are an aspect of palaeoceanography. This discipline depends to a large extent on the use of proxies, in many cases
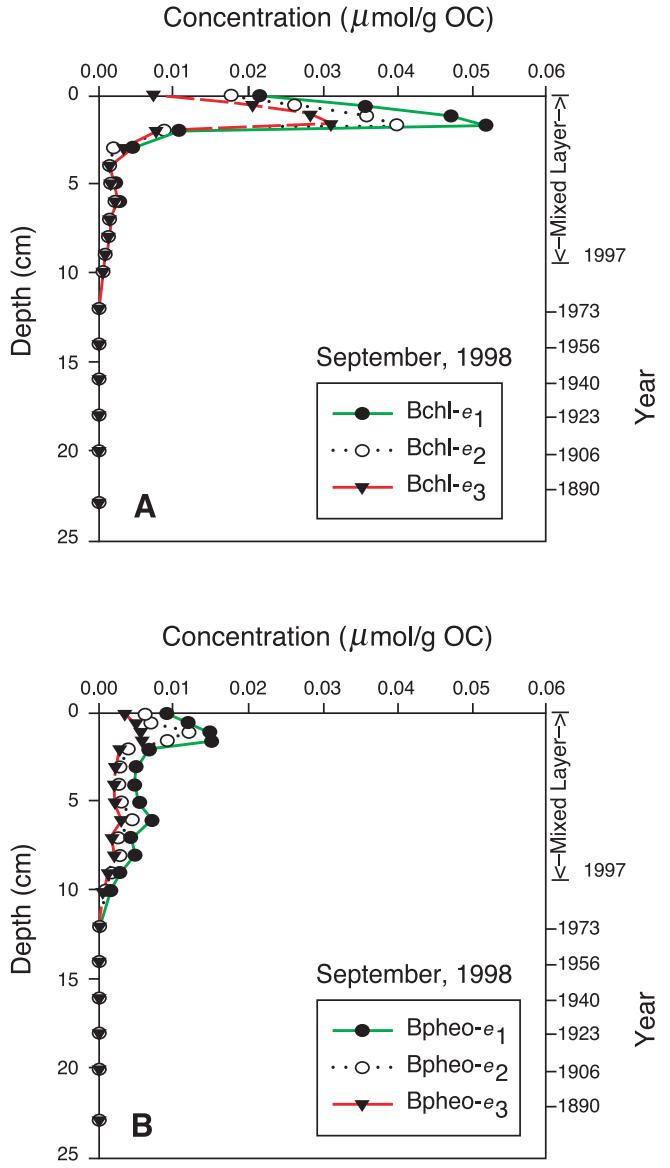

Fig. 16. Down-core concentrations of bacteriochlorophylls- e1, e2 and e3 (indicators of green sulphur bacteria) in two box-core subcores collected in September 1998 from a hypoxic site (PS4 $\sim 27 \mathrm{~m}$ water depth) in a chronically hypoxic area on the Louisiana inner continental shelf, SW of the Mississippi River delta. Bchl-e was not detected below $10 \mathrm{~cm}$ depth in the core. (From Organic Geochemistry, Vol. 32, Chen, N., Bianchi, T. S., McKee, B. A., and Bland, J. M.: Historical trends of hypoxia on the Louisiana shelf: applications of pigments as biomarkers, 543-561, 2001, with permission from Elsevier.)

used in combination, to infer the environmental conditions under which sediments were deposited in former seas and oceans (Hillaire-Marcel and de Vernal, 2007). Palaeoceanographic studies often focus on deep-water, open ocean environments, but also include oxygen-depleted, marginal basins like the Santa Barbara Basin, the Cariaco Basin, or the Saanich Inlet. Time periods studied range from very short ("historical") records to those that cover very long periods, $10^{5}$ years or longer.

The historical studies reviewed in this paper are usually based on nearshore sediment records. Since they require continuous sedimentary sequences, the systems studied are often situated in protected environments, such as inlets or basins. In some cases, documentary records are available and can 
be compared to sediment proxy records (Chesapeake Bay for example). In other areas, human settlements have been sparse and historical information is less complete (Cariaco Basin). However, to a large extent, studies of human impacts are based on proxies preserved in dated sediment cores. Like those conducted in deep-water, open ocean areas, such studies are concerned with environmental changes over time, particularly in surface productivity and bottom-water oxygenation.

In addition to being focussed on coastal waters, historical reconstructions are often relatively local and represent short time periods. Because of high sedimentation rates, coastal records can often be examined at subdecadal or even shorter (annual or seasonal) time scales (Cronin et al., 2003; Rabalais et al., 1996). For example, Black et al. (2007) presented an eight-century record of water temperature (based on $\mathrm{Mg} / \mathrm{Ca}$ ratios and oxygen isotopes) for the Cariaco Basin with a resolution of 1 to 1.5 years. However, because of sample size limitations, there are few proxy studies at these very fine resolutions.

In general, coastal sediments are more dynamic than the floor of the deep ocean, and shallow-water communities are therefore subject to a greater range of environmental influences than those living in the deep sea (Gage and Tyler, 1991). This creates a higher natural variability from which changes caused by human activities must be distinguished. Greater variability in coastal areas compared to deeper water may also make it more difficult to establish a dating framework for sediments. For example, sedimentation rates determined in the top $10 \mathrm{~cm}$ of a core cannot be automatically extrapolated to deeper layers. However, a combination of radioisotopes, including (depending on the site) ${ }^{210} \mathrm{~Pb},{ }^{234} \mathrm{Th}$, ${ }^{7} \mathrm{Be},{ }^{137} \mathrm{Cs}$ and ${ }^{14} \mathrm{C}$, can provide more accurate estimates of sediment age within a single sediment core and help to identify confounding factors such as bioturbation.

The application of palaeoceanographic approaches to reconstruct post-industrial environments in coastal settings requires critical evaluation. Some of the indicators commonly used in palaeoceanography have been applied to historical records but others, for example, the magnetic properties of sediments, trace metals and biomarkers, have been either unused or under-used. Conversely, historical records from coastal areas pose specific problems, leading to the development of proxies (e.g., the Ammonia-Elphidium ratio) that are applicable only in shallow water.

\subsection{Distinguishing hypoxia and eutrophication}

As emphasised elsewhere in this review, it is often difficult to distinguish the effects of hypoxia and eutrophication on proxies preserved in the sediment record. The remains of diatoms, dinocysts, and eukaryotic biomarkers derived from the water column, generally indicate eutrophication, but their preservation is enhanced to a variable extent in oxygen-depleted sediments. Among benthic faunal indicators, certain species and morphotypes of foraminiferans are common in hypoxic environments, However, there are probably no species that are associated specifically with eutrophication in the absence of bottom-water hypoxia. Such conditions are rare in nature, but they occur under the upwelling area off NW Africa. Here, the faunas are rich in uvigerinids and buliminids (Jorissen et al., 1998), which are often considered as low oxygen markers. Conversely, in the Sulu Sea, where fairly low oxygen bottom waters $\left(<2 \mathrm{ml} \mathrm{L}^{-1}\right)$ occur in a moderately oligotrophic context, the density of species traditionally considered as low oxygen markers is surprisingly low (Rathburn and Corliss, 1994). Several experimental studies have tried to distinguish between the effects of hypoxia/anoxia and food input. In general, food addition leads to a reproductive response by the more opportunistic, often small-sized taxa (e.g. Ernst and Van der Zwaan, 2004; Nomaki et al., 2005; Koho et al., 2008). Rather surprisingly, exposure to prolonged periods (up to 2 months) of anoxia does not lead to a disappearance of the dominant taxa (e.g. Bernhard, 1993). Several studies (Duinstee et al., 2003; Ernst and Van der Zwaan, 2004; Geslin et al., 2004) observed migrations of deeper infaunal taxa to the sediment surface. It was suggested that the aim of this upward migration was to avoid hostile anoxic conditions. However, Pucci et al. (in press) showed that upwardly-migrating taxa survive well in anoxic conditions, and so the upward movement is probably a response to a concentration of food at the sediment-water interface rather than an avoidance of oxygen depletion. Thus, both field and laboratory studies suggest that eutrophication has a much stronger impact on the foraminiferal faunas than hypoxia, and that apparent responses to hypoxia may really be responses to organic enrichment.

The degree of sensitivity to hypoxia and eutrophication varies among other proxies (Table 2). Some of the geochemical and biochemical indicators, including redox-sensitive elements such as Mo and Re, and biomarkers (isorenieratene) for photosynthetic sulphur bacteria, appear to be hypoxia specific. However, even in these cases, interpretation is not always simple. Enrichment of Mo, for example, represents conditions at least several $\mathrm{cm}$ deep in the sediment rather than in the overlying water. Bacterial biomarkers may come from bacteria in the water column, or from surficial sediments in the photic zone that are in contact with overlying oxygenated water. Sediment laminations require an absence, or virtual absence, of bioturbating macrofauna and therefore provide good evidence of bottom-water hypoxia, except in areas where sedimentation rates are so high that they prevent bioturbators from colonising the sediment. The best evidence for hypoxic conditions, either in the upper water column or the bottom water, comes from multi-proxy studies. A combination of the above-mentioned proxies that are most strongly influenced by hypoxia with those that reflect a combination of eutrophication and hypoxia (e.g. BSi) can yield the most convincing conclusions, as well as supporting interpretations based on more equivocal indicators (Fig. 6). 


\subsection{Calibration of proxies}

In a thought-provoking critique, Murray (2001) drew attention to a number of problems in the interpretation of proxies based on foraminiferans, particularly indicators for surface productivity and oxygen (see also Murray, 2006). Among the points made by Murray is that the abundance of particular species is related to a particular environmental variable only close to its tolerance limit for that variable. Despite these difficulties, palaeoceanographers have suggested several quantitative, foraminiferal-based approaches to the estimation of hypoxia that could be applied to historical records in coastal settings (Jorissen et al., 2007). All of them involve the recognition of species characteristic of oxic and hypoxic environments. Murray (2006) considers the transfer function proposed by Jannink (2001) to be the "potentially most successful". The argument underlying this proxy is that the relative abundance of oxyphilic species increases as oxygen concentrations rise, because the thickness of the oxygenated, and therefore habitable, sediment layer increases. Jannink et al. (2001) used their method to reconstruct oxygen values based on the 160-year sediment record of Barmawidjaja et al. (1995) from the North Adriatic. The results agreed well with the actual historical oxygen measurements given by Justić et al. (1987). According to Jorissen et al. (2007), however, it is more likely that these shallowinfaunal species respond to inputs of labile organic matter rather than to changes in habitat availability linked to oxygen concentrations. Schmiedl et al. (2003) proposed an interesting method that combined the relative proportion of oxyphilic species ("high oxygen indicators") with a measure of species diversity. The degree of oxygenation was indicated on a scale of 0 (anoxic) to 1 (oxic) rather than by actual values. The authors applied it to Mediterranean sapropels with convincing results (Fig. 17). Another proxy widely used by palaeoceanographers to estimate bottom-water oxygen levels is the Benthic Foraminiferal Oxygen Index (BFOI) of Kaiho (1994, 1999).

All current foraminiferal-based oxygen proxies suffer from drawbacks (Jorissen et al., 2007), the most severe being the inversely-related effects of organic fluxes and oxygen concentrations (Levin and Gage, 1998; Gooday, 2003). Also, most foraminiferans live within the sediment and therefore reflect oxygen levels within the sediment pore-water rather than in the overlying water (Gooday et al., 2000; Murray, 2001; Jorissen et al., 2007). This can lead to deep-infaunal, hypoxia-tolerant taxa being abundant in settings where the bottom-water is fully oxic (Sen Gupta et al., 1981; Jorissen et al., 1998; Gooday et al., 2001; Fontanier et al., 2005). Jorissen et al. (2007) suggest that below a certain threshold, the proportion of deep-infaunal foraminiferans depends on the elimination of less tolerant species by hypoxia. Hence, at least in principle, the percentage of deep-infaunal taxa can be used as a quantitative estimator of bottom-water oxygenation. Jorissen et al. (2007) suggest that for such a proxy to be reliable, it needs to be calibrated by reference to values derived from modern assemblages over a range of bottom-water oxygen concentrations between 0 and $2 \mathrm{ml} \mathrm{L}^{-1}(=0-87 \mu \mathrm{M})$. Because benthic foraminiferal species used to reconstruct anthropogenic hypoxia in coastal settings are often still living in the same area, it should be easier to calibrate and test them according to the criteria set out by Jorissen et al. (2007).

Few other attempts have been made to quantify bottomwater oxygen proxies. Willard et al. (2003) estimated dissolved oxygen values in cores from Chesapeake Bay using a modern analogue technique based on dinocyst species (Fig. 13). Building on the biofacies approach of Savrda and Bottjer (1991), Behl (1995) recognised seven sedimentary facies in the Santa Barbara Basin, including four ranging from completely bioturbated to completely laminated. Behl and Kennett (1996) correlated these to oxygen concentrations of $<0.1 \mathrm{ml} \mathrm{L}^{-1}(<4.3 \mu \mathrm{M}$; well-laminated sediment), $\sim 0.1 \mathrm{ml} \mathrm{L}^{-1}(\sim 4.3 \mu \mathrm{M}$; bioturbation limited to meiofauna, insufficient to destroy laminations), $0.1-0.2 \mathrm{ml} \mathrm{L}^{-1}(4.3-$ $8.6 \mu \mathrm{M}$; partial homogenisation) and $>0.3 \mathrm{ml} \mathrm{L}^{-1}(>13 \mu \mathrm{M}$; homogenised sediment) (Fig. 18). The $0.1 \mathrm{ml} \mathrm{L}^{-1}$ bioturbation threshold is consistent with recent evidence from the Pakistan margin. However, it appears that the responses by benthic organisms to hypoxia are different in deep and shallow water (Levin et al., 2009), suggesting that quantitative proxies of oxygenation developed in the deep sea may not be directly applicable to coastal settings.

\subsection{Natural versus anthropogenic drivers of hypoxia}

Areas of seafloor overlain by naturally oxygen-depleted water masses are widespread in deeper water, e.g. the Cariaco and Santa Barbara Basins, the Black Sea, Kau Bay, and oxygen minimum zones, and greatly exceed those affected by anthropogenically-induced hypoxia (Naqvi et al., 2000; Helly and Levin, 2004). In shallow water, natural decadal or multidecadal climatic shifts linked to changes in indices such as the North Atlantic Oscillation (NAO) can have a major impact, particularly on coastal ecosystems where seasonal hypoxia can develop as a result of increased water column stratification during the summer linked to increased precipitation and freshwater runoff (Saegner et al., 2006; Cronin and Walker, 2006; Willard and Cronin, 2007; Leipe et al., 2008). Although the trend in most river-dominated coastal systems is for an increase in the $\mathrm{N}$ and $\mathrm{P}$ loads over the last half century (Boesch, 2002; Turner et al., 2003 a, b), hypoxia may also develop naturally off the mouths of major rivers (Van der Zwaan, 2000). When interpreting proxy records that suggest hypoxia, it is therefore important to keep in mind possible natural causes, often linked to climatic variation, in addition to human influences (Murray and Alve, 2002). Historical records, such as official documents and unofficial journals, can also be useful in distinguishing human from natural drivers of hypoxia (Jackson et al., 2001). 
Oxygenation

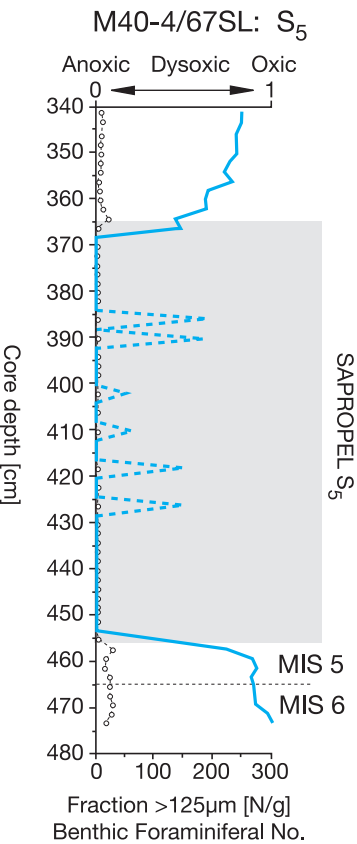

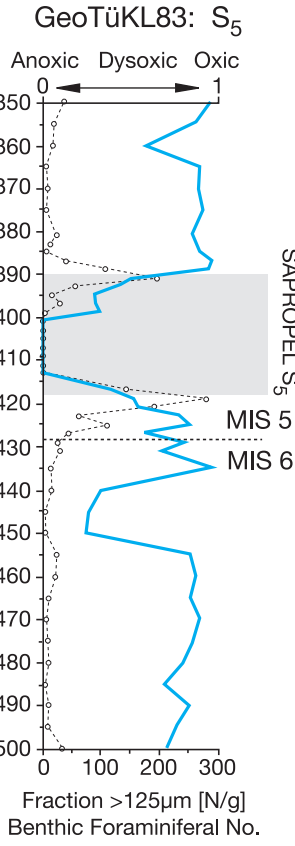

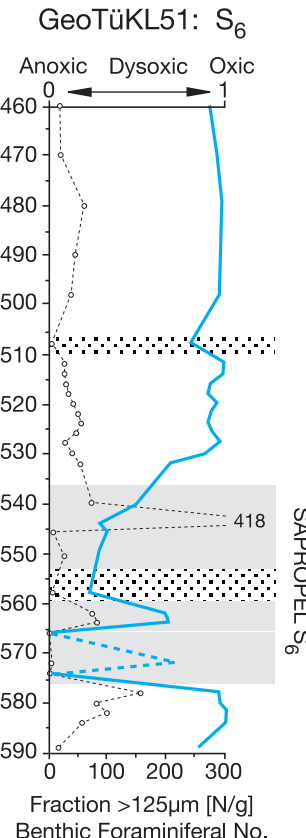

Fig. 17. Application of the "Schmiedl proxy" for bottom-water oxygenation to Mediterranean sapropels. Relative changes of oxygenation (thick blue line) across sapropels S5 and S6 from the lower bathyal western (core M40-4/67SL) and middle bathyal eastern (core GeoTuKL83) Levantine Basin. Oxygen estimates are based on the ratio $(\mathrm{HO} /(\mathrm{HO}+\mathrm{LO})+\mathrm{Div}) \mathrm{U} 0.5$, where $\mathrm{HO}=$ the relative abundance of high oxygen indicators (Miliolids - Articulina tubulosa + Cibicidoides pachydermus + Gyroidinoides orbicularis), LO=relative abundance of low oxygen indicators (Fursenkoina spp., Chilostomella oolina, Globobulimina spp.), and normalized benthic foraminiferal diversity (H(S) normalized). Intervals where oxygen contents are likely to be overestimated due to very low benthic foraminiferal numbers (BFN, number of individuals per $\mathrm{g}$ of sediment) are indicated by stippled line. The BFN for the size fraction $>125 \mu \mathrm{m}$ is given for comparison (thin line with dots). (From Palaeogeography Palaeoclimatology, Palaeoecology, Vol. 190, Schmiedl, G., Mitschele, A., Beck, S., Emeis, K. C., Hemleben, C., Schulz, H., Sperling, M., and Weldeab, S.: Benthic foraminiferal record of ecosystem variability in the eastern Mediterranean Sea during times of sapropel S5 and S6 deposition, 139-164, 2003, with permission from Elsevier.)

There are several examples of systems where anthropogenically-induced hypoxia is superimposed on natural cycles that have persisted over much longer time scales. Cronin and Vann (2003) review studies in Chesapeake Bay that used different oxygen-related proxies to identify periods of hypoxia lasting several decades, prior to the European colonization of North America (Fig. 7). In the absence of significant human activity, it is relatively easy to recognise these as natural events. They were probably related to changes in atmospheric circulation that caused climatic variations in the mid-Atlantic, for example, the North Atlantic Oscillation (Cronin et al., 2000, 2003). However, over the last 300 years, a combination of factors has modified Chesapeake Bay and the picture has become more complicated. Between 1700 and 1900, progressive eutrophication linked to forest clearance, which intensified erosion and the delivery of nutrients to the Bay, was superimposed on climatic changes involving periods of increased precipitation, run off, water column stratification and oxygen depletion. During the latter part of the 20th Century, human activities were the main cause of dramatically decreasing oxygen levels, but at times, climatic forcing probably still played a role (Cronin and Vann, 2003; Willard and Cronin, 2007). Understanding the interplay between natural climate forcing and human activities is key to conservation of habitat for two anadromous sturgeon species in Chesapeake Bay, one of which is endangered (Willard and Cronin, 2007). Faunal and geochemical proxies have revealed similar natural hypoxic events related to climatic fluctuations in sediment records from the Louisiana shelf (Swarzenski et al., 2008).

The influence of natural processes is also evident in Scandinavia, where isostatic uplift following the last deglaciation has reduced sill depth of some Norwegian fjords, inhibiting water exchange with the open sea, trapping particulate matter and promoting anoxic conditions (Pinturier-Geiss et al., 2002; Smittenberg et al., 2004; Husum and Alve, 2006). Other processes have been at work in the Gullmar Fjord, an unpolluted (since 1966) fjord on the Swedish west coast. Here, there has been a shift from a fairly diverse 


\section{Sedimentary fabric Bioturbation index}

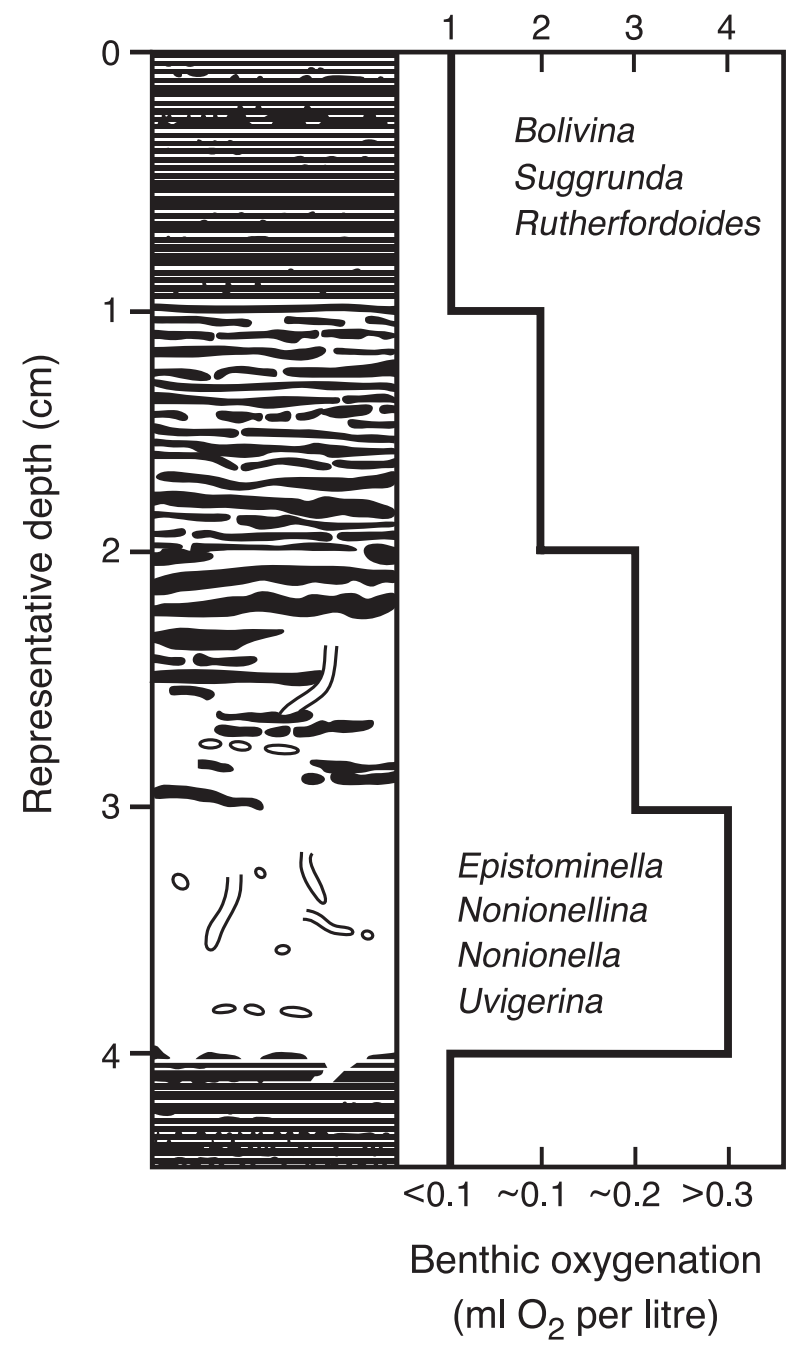

Fig. 18. Bioturbation index (BI) based the development of sediment laminations; application to sediments from Santa Barbara Basin (576-m water depth), NE Pacific. BI value $1=$ sediments with distinct, continuous laminations. BI value $2=$ diffuse, discontinuous irregular laminations. BI value $3=$ slightly bioturbated with either faint, diffuse laminations or a few discrete patches of laminations surrounded by homogenized sediment, including local Chrondrites burrows. BI value $4=$ completely bioturbated, finegrained sediments with no discernable fabric and commonly containing echinoid spines. Characteristic foraminiferans are listed for two end-member facies. The four facies recognized are believed to correspond approximately to the following oxygen concentrations: $<0.1 \mathrm{~mL} \mathrm{~L}^{-1}(<4.3 \mu \mathrm{M}$; facies 1$)$, macrofaunal excluded; $0.1 \mathrm{mLL}^{-1}(4.3 \mu \mathrm{M}$; facies 2$)$, meiofaunal bioturbation causing laminations to become diffuse; $0.1-0.2 \mathrm{~mL} \mathrm{~L}^{-1}(4.3-8.6 \mu \mathrm{M}$; facies 3), enough oxygen to permit partial homogenization of sediment by fauna; $>0.3 \mathrm{mLL}^{-1}$ (>13 $\mu \mathrm{M}$; facies 4$)$, macrofauna present. Reprinted from Behl and Kennett, 1996, with permission from Macmillan Publishers Ltd (Nature). foraminiferal assemblage comprising typical shelf species also found in the adjacent Skaggerak/Kattegat to an assemblage dominated by the opportunistic, hypoxia-tolerant species Stainforthia fusiformis (Nordberg et al., 2000; Filipsson and Nordberg, 2004). The change to a S. fusiformis dominated assemblage mirrored that seen in Frierfjord, Norway, where the underlying cause was clearly anthropogenic (Alve, 2000). In the Gullmar Fjord, however, the assemblage change coincided with a severe hypoxic event that occurred during the 1979/1980 winter and was sustained by an increased input of phytodetritus. A variety of climatic and oceanographic factors, including changes in the North Atlantic Oscillation leading to predominantly westerly winds that inhibited the exchange of bottom water in the fjord and in the flow of Atlantic water into the North Sea, are believed to underlie this faunal shift (Filippson and Nordberg, 2004). Similarly, hypoxic bottom water has developed intermittently in the deep basins of Baltic Sea for thousands of years as a result of climatic forcing, and has been overprinted by human influences only in recent decades (Zillén et al., 2008; Conley et al., 2009). In open-shelf settings, similar changes have arisen from alterations in the hydrodynamic regime related ultimately to climatic forcing, for example, on the northwestern Iberian shelf (Martins et al., 2007) and off Oregon (Grantham et al., 2004).

\section{Future directions}

1) The number of coastal areas that are oxygen-depleted to the extent that living resources are compromised continues to rise (Diaz and Rosenberg, 1995, 2008; Diaz, 2001; Rabalais and Gilbert, 2008). There is an increasing need to study proxy records to recognise that changes are occurring so that management interventions can be applied before the coastal ecosystem has declined irreparably (Rabalais et al., 2007). Areas of incipient hypoxia where the historical approach might be applicable exist off the Changjian (Yantze River) in the East China Sea (Li and Daler, 2004; Chen et al., 2007; Wei et al., 2007) and in the southwestern Gulf of Mexico off the Coatzoalcos River (Rabalais, 2004). Palaeoindicators of eutrophication and hypoxia in the Charlotte Harbor estuary in Florida prompted the water management authorities to begin planning improved waste-water treatment plants for expected population increases. In other areas, where industrialization and mechanized agriculture are trying to keep pace with a burgeoning population, management and remediation measures are less well developed. Unfortunately, research on sediment records is often small in scale and not well funded compared to programmes designed to monitor impacted ecosystems.

2) As more and more coastal systems are impacted by human activities, either directly or indirectly through consequences such as climate change, our ability to document a "natural" coastal ecosystem becomes increasingly difficult. It is essential that these baseline conditions should be 
described before it is too late. The variability of existing relatively pristine systems, for example, in polar regions, should also be documented in order to distinguish between natural variation and anthropogenic impacts.

3) Distinguishing the effects of eutrophication from hypoxia remains a difficult challenge. Many proxies reflect both phenomena; for example, increased pigment concentrations can be due to both enhanced preservation under oxygen-depleted conditions or elevated production. The use of multiple indicators, i.e. a combination of proxies related to eutrophication (e.g. diatoms, phytoplankton pigments, BSi) with hypoxia-specific proxies (redox-sensitive trace elements such as Mo, Rh, bacterial pigments, indicators derived from sulphide minerals), may help to distinguish between these two closely-related drivers of ecosystem change. Examples of this approach are provided by the studies of Zimmerman and Canuel (2002) and Turner et al. (2006).

4) Proxies require verification and calibration. Collections across a range of oxygen concentrations will help to relate bioindicators to ambient oxygen concentrations. In order to improve the reliability of faunal proxies, it is important to identify organisms that were living when collected. Fluorescent dyes may be an improvement on traditional methods such as rose Bengal staining, which can yield false positives, particularly under hypoxic conditions (Bernhard, 2000). Laboratory-based experiments conducted using a range of coastal sediments, for example, to examine the geochemical responses of various metals and trace metals to lowered oxygen concentrations or anoxic conditions, provide another approach to calibration. Clearly, the development of quantitative proxies for hypoxia involves considerable challenges. Nevertheless, quantitative estimates of past climatic parameters, notably temperature, have been developed based on tree rings (Briffa et al., 2004, 2008; Yadav and Singh, 2001) and fossil beetles (Huppert and Solow, 2004). Similarly, transfer functions based on planktonic foraminiferans and dinocysts have been used to estimate sea-surface temperatures during the last glacial maximum (CLIMAP Project Members, 1976) and modern primary productivity, temperature and salinity (Radi et al., 2007, 2008), respectively. Given a large enough dataset, it may be possible to develop similar approaches to the quantification of past hypoxia.

6) There is considerable scope for the refinement of existing proxies and the development of new ones. More use could be made of animal hard parts; for example, the carapaces of ampeliscid amphipods, polychaete setae, the jaws of dorvilleid polychaetes, echinoderm spines and ossicles and the shells of chemosynthetic bivalves (e.g. Thyasira). These and other taxa may form sucessional sequences in response to spatial or temporal oxygen gradients in coastal and deeperwater settings (Harper et al., 1991; Diaz and Rosenberg, 1995; Rabalais et al., 2001; Rosenberg, 2001). Some proxies, including trace metals such as rhenium and the magnetic properties of sediments, have yet to be applied to records of human-induced hypoxia. Finally, there is a need for a better understanding of the ecology and biogeography of important indicator species (e.g. some foraminiferans and dinocysts) in order to determine if they can be used universally or only locally

Acknowledgements. We thank T. Cronin, B. S. Gupta, and an anonymous reviewer for their helpful comments on the manuscript. D. Gilbert, D. Conley, and H. Kitazato also commented on the manuscript and kindly drew our attention to some important references. K. Davis drew or redrew most of the figures. This paper is a contribution to OCEANS 2025, a co-ordinated marine science programme of the Natural Environment Research Council (UK).

Edited by: D. Gilbert

\section{References}

Adelson, J. M., Helz, G. R., and Miller, C. V.: Reconstructing the rise of coastal anoxia: molybdenum in Chesapeake Bay sediments, Geochim. Cosmochim. Ac., 65, 237-252, 2001.

Agnihotri, R., Kurian, S., Fernandes, M., Reshma, K., D’Souza,W., and Naqvi, S. W. A.: Variability of subsurface denitrification and surface productivity in the coastal eastern Arabian Sea over the past seven centuries, Holocene, 18, 755-764, 2008.

Altabet, M. A. and Francois, R.: Sedimentary isotopic ratio as a recorder for surface ocean nitrate utilization, Global Biogeochem. Cy., 8, 103-116, 1994.

Alvarez Zarikian, C. A., Blackwelder, P. L., Hood, T., Nelsen, T. A., and Featherstone, C.: Ostracods as indicators of natural and anthropogenically induced changes in coastal marine environments, in: Coasts at the Millennium, Proceedings of the 17th International Conference of The Coastal Society, Portland, OR USA, July 9-12, 896-905, 2000.

Alve, E.: Variations in estuarine foraminiferal biofacies with diminishing oxygen conditions in Drammensfjord, SE Norway, in: Paleoecology, Biostratigraphy and Taxonomy of Agglutinated Foraminifera, edited by: Hemleben, C., Kaminski, M., Kuhnt, W., and Scott, D. B., Kluwer, Dordrecht, The Netherlands, 661694, 1990.

Alve, E.: Foraminifera, climatic change, and pollution: a study of late Holocene sediments in Drammensfjord, southeast Norway, Holocene, 1, 243-261, 1991.

Alve, E.: Benthic foraminiferal responses to estuarine pollution: a review, J. Foramin. Res., 25, 190-203, 1995.

Alve, E.: Environmental stratigraphy. A case study reconstructing bottom water oxygen conditions in Frierfjord, Norway, over the past five centuries, in: Environmental Micropaleontology of Topics in Geobiology, edited by: Martin, R.E., 15, Kluwer Academic/Plenum Publishing, New York, USA, 323-350, 2000.

Alve, E.: A common opportunistic foraminiferal species as an indicator of rapidly changing conditions in a range of environments, Estuar. Coast. Shelf Sci., 57, 501-514, 2003.

Alve, E.: From blue skies science to practical application: Increasing need for retrospective in environmental micropaleontological monitoring (REMM), in: Forams 2006, Book of Abstracts, Anuário do Instituto de Geociências - UFRJ 29, 520-521, 2006.

Alve, E. and Murray, J. W.: Benthic foraminiferal distribution and abundance changes in Skagerrak surface sediments: 1937 (Höglund) and 1992/93 data compared, Marine Micropaleontol., 25, 269-288, 1995. 
Andrén, E.: Changes in the composition of the marine diatom flora during the past century indicate increased eutrophication of the Oder estuary, southwestern Baltic Sea, Estuar. Coast. Shelf. S., 48, 665-676, 1999.

Andrén, E., Shimmield, G., and Brand, T.: Changes in the environment during the last centuries on the basis of siliceous microfossil records from the southwestern Baltic, Holocene, 9, 25-38, 1999.

Arnaboldi, M., and Meyers, P. A.: Trace element indicators of increased primary production and decreased water-column ventilation during deposition of latest Pliocene sapropels at five locations across the Mediterranean Sea, Palaeogeogr. Palaeocl., 249, 425-443, 2007.

Barmawidjaja, D. M., van der Zwaan, G. J., Jorissen, F. J., and Puškarik, S.: 150 years of eutrophication in the northern Adriatic Sea: Evidence from benthic foraminiferal records, Mar. Geol., 122, 367-384, 1995.

Behl, R. J.: Sedimentary facies and sedimentology of the late Quaternary Santa Barbara Basin, Site 893, Proceedings Ocean Drilling Program Scientific Results, 146, 295-308, 1995.

Behl, R. J. and Kennett, J. P.: Brief interstadial events in the Santa Barbara Basin, NE Pacific, during the last $60 \mathrm{kyr}$, Nature, 379, 243-246, 1996.

Bennion, H., Juggins, S., and Anderson, N. J.: Predicting epilimnetic phosphorus concentrations using an improved diatombased transfer function and its application to lake eutrophication management, Environ. Sci. Technol., 20, 2004-2007, 1996.

Berner, R. A.: Sedimentary iron formation: An update, Geochim. Cosmochim. Ac., 48, 605-615, 1984.

Bernhard, J. M.: Distinguishing live from dead Foraminifera: methods review and proper applications, Micropaleontology, 46 (Suppl.1, Advanced in the Biology of Foraminifera), 38-46, 2000.

Bernhard, J. M. and Sen Gupta, B. K.: Foraminifera in oxygendepleted environments, in: Modern Foraminifera, edited by: Sen Gupta, B. K., Kluwer Academic Publishers, Dordrecht, Boston, London, 201-216, 1999.

Bianchi, T. S., Engelhaupt, E., Westman, P., Andrén, T., Rolf, C., and Elmgren, R.: Cyanobacterial blooms in the Baltic Sea: natural or human-induced? Limnol. Oceanogr., 45, 716-726, 2000.

Bianchi, T. S., Johansson, B., and Elmgren, R.: Breakdown of phytoplankton pigments in Baltic sediments: effects of anoxia and loss of deposit-feeding macrofauna, J. Exp. Mar. Biol. Ecol., 251, 161-183, 2000.

Black, D. E., Abahazi, M. A., Thunell, R. C., Kaplan, A., Tappa, E. J., and Peterson, L. C.: An 8-century tropical Atlantic SST record from the Cariaco Basin: Baseline variability, twentieth-century warming, and Atlantic hurricane frequency, Paleoceanography, 22, PA4204, doi:10.1029/2007PA001427, 2007.

Blackwelder, P., Hood, T., Alvarez Zarikian, C. A., Nelsen, T. A., and McKee, B.: Benthic Foraminifera from the NECOP study area impacted by the Mississippi River plume and seasonal hypoxia, Quatern. Int., 31, 19-36, 1996.

Blazejak, A., Erseus, C., Amann, R., and Dubilier, N.: Coexistence of bacterial sulfide oxidizers, sulfate reducers and spirochetes in a gutless worm (Oligochaeta) from the Peru margin, Appl. Environ Microb., 71, 1553-61, 2005.

Boesch, D. F.: Challenges and opportunities for science in reducing nutrient over-enrichment of coastal ecosystems, Estuaries,
25, 886-900, 2002.

Brandes, J. A. and Devol, A. H.: A global marine-fixed nitrogen isotopic budget: Implications for Holocene nitrogen cycling, Global Biogeochem. Cy., 16, 1120, doi:10.1029/2001GB001856, 2002.

Brandes, J. A., Devol, A. H., Yoshinari, T., Jayakumar, A., and Naqvi, S. W. A.: Isotopic composition of nitrate in the central Arabian Sea and eastern tropical North Pacific: A tracer for mixing and nitrogen cycles, Limnol. Oceanogr., 43, 1680-1689, 1998.

Boomer, I.: Environmental applications of marine and freshwater Ostracoda, in: Quaternary Environmental Micropalaeontology, edited by: Haslett, S. K., Arnold, London, UK, 115-138, 2002.

Bratton, J. F., Colman, S. M., and Seal, R. R.: Eutrophication and carbon sources in Chesapeake Bay over the last $2700 \mathrm{yr}$ : human impacts in context, Geochim. Cosmochim. Ac., 67, 3385-3402, 2003.

Bréhéret, J.-G.: Glauconitization episodes in marginal settings as echoes of mid-Cretaceous anoxic events in the Vocontian basin (SE France), in: Modern and Ancient Continental Shelf Anoxia, edited by: Tyson, R. V. and Pearson, T. H., Geol. Soc. Sp., 58, 415-425, 1991.

Briffa, K. R., Osborn, T. J. and Scheingruber, F. H.: Large-scale temperature inferences from tree rings: a review, Global Planet. Change, 40, 11-26, 2004.

Briffa, K. R., Shishov, V. V., Melvin, T. M., Vaganov, E. A., Grudd, H., Hantemirov, R. M., Eronen, M. and Naurzbaev, M. M.: Trends in recent temperature and radial tree growth spanning 2000 years across northwest Eurasia, Philos. T. Roy. Soc. B, 363, 2271-2284, 2008.

Bruland, K. W. and Lohan, M. C.: The control of trace metals in seawater, in: The Oceans and Marine Geochemistry, edited by: Elderfield, H., Treatise on Geochemistry, Elsevier- Pergamon, Oxford, UK, 6, 23-47, 2003.

Brunner, C. A., Beall, J. M., Bentley, S. J., and Furukawa, Y.: Hypoxia hotspots in the Mississippi Bight, J. Foramin. Res., 36, 95-107, 2006.

Brush, G. S.: Stratigraphic evidence of eutrophication in an estuary, Water Resour. Res., 20, 531-541, 1984.

Brush, G. S.: Natural and anthropogenic changes in Chesapeake Bay during the last 1000 years, Human Ecology and Risk Assessment, 7, 1283-1296, 2001.

Brush, G. S. and Hilgartner, W. B.: Paleoecology of the submerged macrophytes in the Upper Chesapeake Bay, Ecol. Monogr., 70, 645-667, 2000.

Calvert, S. E. and Pedersen, T. F.: Elemental proxies for palaeoclimatic and palaeoceanographic variability in marine sediments: interpretation and application, in: Proxies in Late Cenozoic Paleoceanography, edited by: Hillaire-Marcel, C. and de Vernal, A., Elsevier, Amsterdam, Boston, Heidelberg, London, New York, Oxford, Paris, San Diego, San Francisco, Singapore, Sydney, Tokyo, 567-644, 2007.

Canfield, D. E. and Thamdrup, B.: The production of ${ }^{34}$ S-depleted sulfide during bacterial disproportionation to elemental sulfur, Science, 266, 1973-1975, 1994.

Cearreta, A., Irabien, M. J., Leorri, E., Yusta, I., Croudace, I. W., and Cundy, A. B.: Recent anthropogenic impacts on the Bilbao estuary, northern Spain: geochemical and macrofaunal evidence, Estuar. Coast. Shelf Sci., 50, 571-592, 2000.

Cearreta, A., Irabien, M. J., Leorri, E. A., Yusta, I., Quintanilla, A., 
and Zabaleta, A..: Environmental transformation of the Bilbao estuary, northern Spain: microfaunal and geochemical evidence in the recent sedimentary record, Mar. Pollut. Bull., 44, 487-503, 2002.

Chen, C.-C., Gong, G.-C., and Shiah, F.-K.: Hypoxia in the East China Sea: One of the largest coastal low-oxygen areas in the world, Marine Environ. Res., 64, 399-408, 2007.

Chen, N., Bianchi, T. S., McKee, B. A., and Bland, J. M.: Historical trends of hypoxia on the Louisiana shelf: applications of pigments as biomarkers, Org. Geochem., 32, 543-561, 2001.

Chmura, G. L., Santos, A., Pospelova, V., Spasojevic, Z., Lam, R., and Latimer, J.S.: Response of three paleo-primary production proxy measures to development of an urban estuary, Science Total Environ., 320, 225-243, 2004.

Clarke, A., Juggins, S., and Conley, D.: A 150-year reconstruction of the history of coastal eutrophication in Riskilde Fjord, Denmark, Mar. Pollut. Bull., 46, 1615-1629, 2003.

Clarke, A. L., Weckström, K., Conley, D. J., Anderson, N. J., Adser, F., Andrén, E., de Jonge, V. N., Ellegaard, M., Juggins, S., Kauppila, P., Korhola, A., Reuss, N., Telford, R. J., and Vaalgamaa, S.: Long-term trends in eutrophication and nutrients in the coastal zone, Limnol. Oceanogr., 51, 385-397, 2006.

Cole, M. L., Valiela, I., Kroeger, K. D., Tomasky, G. L., Cebrian, J., Wigand, C., McKinney, R. A., Grady, S. P., and Carvalho da Silva, M. H.: Assessment of a $\delta^{15} \mathrm{~N}$ isotopic method to indicate anthropogenic eutrophication in aquatic ecosystems, J. Environ. Qual., 33, 124-132, 2004.

Colman, S. M. and Bratton, J. F..: Anthropogenically induced changes in sediment and biogenic silica fluxes in Chesapeake Bay, Geology, 31, 71-74, 2003.

Colman, S. M., Baucom, P. C., Bratton, J. F., Cronin, T. M., McGeehin, J. P., Willard, D., Zimerman, A. R., and Vogt, P. R.: Radiocarbon dating, chronologic framework, and changes in accumulation rates of Holocene estuarine sediments from Chesapeake Bay, Quaternary Res., 57, 58-70, 2002.

Conley, D. J., Björck, S., Bonsdorff, E., Carstensen, J., Destouni, G., Gustafsson, B. G., Hietanen, S., Kortekaas, M., Kuosa, H., Markus Meier, H. E., Müller-Karulis, B., Nordberg, K., Norkko, A., Nürnberg, G., Pitkänen, H., Rabalais, N. N., Rosenberg, R., Savchuk, O. P., Slomp, C. P., Voss, M., Wulff, F., and Zillén, L.: Hypoxia-related processes in the Baltic Sea, Environ. Sci. Technol., 43, 3412-3419, 2009.

Conley, D. J., Carstensen, J., Ártebjerg, G., Christiansen, P. B., Dalsgaard, T., Hansen, J. L. S., and Josefson, A. B.: Long-term changes and impacts of hypoxia in Danish coastal waters, Ecol. Appl., 17(5) Supplement, S165-S184, 2007.

Cooper, S. R.: Chesapeake Bay watershed historical land use: impact on water quality and diatom communities. Ecol. Appl., 5, 703-723, 2005.

Cooper, S. R.: History of human impacts on ecology of North Carolina estuaries, in: Geological Society of America 2006 Philadelphia Annual Meeting (22-25 October 2006), Paper N. 130-13, 2006.

Cooper, S. R., and Brush, G. S.: Long term history of Chesapeake Bay anoxia, Science, 254, 992-996, 1991.

Cooper, S. R. and Brush, G. S.: A 2500-year history of anoxia and eutrophication in Chesapeake Bay, Estuaries, 16, 617-626, 1993.

Corbari, L., Mesmer-Dudons, N., Carbonel, P., and Massabuau, J. C.: Cytherella as a tool to reconstruct deep-sea paleo-oxygen levels: the respiratory physiology of the platycopid ostracod Cytherella cf. abyssorum, Mar. Biol., 147, 1377-1386, 2005.

Cornwell, J. C., Conley, D. J., Owens, M., and Stephenson, J. C.: A sediment chronology of Chesapeake Bay, Estuaries, 19, 488499, 1996.

Cornwell, J. C., Fisher T. R., Glibert P. M., Hagy J. D., Harding L. W., Houde E. D., Kimmel D. G., Miller W. D., Newell R. I .E., Roman M. R., Smith E. M., and Stevenson J. C.: Eutrophication of Chesapeake Bay: historical trends and ecological interactions, Marine Ecol. Prog. Ser., 303, 1-29, 2005.

Cowie, G. L.: The biogeochemistry of Arabian Sea surficial sediments: A review of recent studies, Prog. Oceanogr., 65, 260-289, 2005.

Cowie, G. L. and Levin, L. A.: Benthic biological and biogeochemical patterns and processes across an oxygen minimum zone (Pakistan Margin, NW Arabian Sea), Deep-Sea Res. II, 56, 261-270, 2009.

Crosta, X. and Koç, N.: Diatoms: from micropaleontology to isotope geochemistry, in: Proxies in Late Cenozoic Paleoceanography, edited by: Hillaire-Marcel, C. and de Vernal, A., Elsevier, Amsterdam, 327-369, 2007.

Cronin, T. M. and Vann, C. D.: The sedimentary record of climatic and anthropogenic influence on the Patuxent Estuary and Chesapeake Bay ecosystems, Estuaries, 26, 196-209, 2003.

Cronin, T. M., Willard, D. A., Karlsen, A., Ishman, S., Verado, S., McGeehin, J., Kerhin, R., Holmes, C., Colman, S., and Zimmerman, A.: Climatic variability in the eastern United States over the past millennium from Chesapeake Bay sediments, Geology, 28, 3-6, 2000.

Cronin, T. M., Dwyer, D. S., Kamiya, T., Schwede, S., and Willard, D. A.: Medieval warm period, little ice age and 20th century temperature variability from Chesapeake Bay, Global Planet. Change, 36, 17-29, 2003.

Crosta, X. and Koç, N.: Diatoms: from micropaleontology to isotope geochemistry, in: Proxies in Late Cenozoic Paleoceanography, edited by: Hillaire-Marcel, C. and de Vernal, A., Elsevier, Amsterdam, Boston, Heidelberg, London, New York, Oxford, Paris, San Diego, San Francisco, Singapore, Sydney, Tokyo, 327-369, 2007.

Crusius, J., Calvert, S., Pedersen, T., and Sage, D.: Rhenium and molybdenum enrichments in sediments as indicators of oxic, suboxic and sulfidic conditions of deposition, Earth, Planet. Sc. Lett., 145, 65-78, 1996.

D'Souza, A. W.: Reconstruction of past changes in the oxygen minimum zone of the Arabian Sea from sedimentary record. Ph.D. thesis, Goa University, 180 pp., 2007.

Dale, B.: Dinoflagellate cysts as indicators of cultural eutrophication and industrial pollution in coastal sediments, in: Environmental Micropaleontology, Volume 15 of Topics in Geobiology, edited by: Martin, R. E., Kluwer Academic/Plenum Publishing, New York, 305-321, 2000.

Dale, B. and Dale, A.: Environmental applications of dinoflagellate cysts and acritachs, in: Quaternary Environmental Micropalaeontology, edited by: Haslett, S. K., Arnold, London, UK, 207-240, 2002.

Dale, B., Thorsen, T. A., and Fjellså, A.: Dinoflagellate cysts as indicators of cultural eutrophication in the Oslofjord, Norway, Estuar. Coast. Shelf Sci., 48, 371-146, 1999.

Debenay, J. P., and Guillou, J.-J.: Ecological transitions indicated 
by foraminiferal assemblages in paralic environments, Estuaries, 25, 1107-1120, 2002.

Diaz R. J. and Rosenberg, R.: Marine benthic hypoxia: A review of its ecological effects and the behavioural responses of benthic macrofauna, Oceanogr. Mar. Biol. Ann. Rev., 33, 245-303, 1995.

Díaz, R. J. and Rosenberg, R.: Spreading dead zones and consequences for marine ecosystems, Science, 321, 926-929, 2008.

Diaz, R. J.: Overview of hypoxia around the world, J. Environ. Qual., 30, 275-281, 2001.

Dortch, Q., Robichaux, R., Pool, S., Milstedl, D., Mire, G. Rabalais, N. N., Soniat, T. M., Fryxel, G. R., Turner, E., and Parsons, M. L.: Abundance and vertical flux of Pseudo-nitzschia in the northern Gulf of Mexico, Marine Ecol. Prog. Ser., 146, 249-264, 1997.

Duijnstee, I. A. P., Ernst, S. R., and Van der Zwaan, G. J.: Effect of anoxia on the vertical migration of benthic foraminifera, Mar. Ecol. Prog. Ser., 246, 85-94, 2003.

Eadie, B. J., McKee, B. A., Lansing, M. B., Robbins, J. A., Metz, S., and Trefry, J. H.: Records of nutrient-enhanced coastal productivity in sediments from the Louisiana continental shelf, Estuaries, 17, 754-765, 1994.

Ellegaard, M., Clarke, A. L., Reuss, N., Drew, S., Weckstrom, K., and Juggins, S., Anderson N. J., and Conley D. J.: Multi-proxy evidence of long-term changes in ecosystem structure in a Danish marine estuary, linked to increased nutrient loading, Estuar. Coast. Shelf S., 68, 567-578, 2006.

Ernst, S. R. and Van der Zwaan, G. J.: Effects of experimentally induced raised levels of organic flux and oxygen depletion on a continental slope benthic foraminiferal community, Deep-Sea Res. I, 51, 1709-1739, 2004.

Ficken, K. J. and Farrimond, P.: Sedimentary lipid geochemistry of Framvaren: impacts of a changing environment, Mar. Chem., 51, 31-43, 1995.

Filipsson, H. L. and Nordberg, K.: Climatic variations, an overlooked factor influencing the recent marine environment. An example from the Gullmar Fjord, Sweden, illustrated by benthic foraminifera and hydrographic data, Estuaries, 27, 867-881, 2004.

Fontanier, C., Jorissen, F. J., Chaillou, G., Anschutz, P., Grémare, A., and Griveaud, C.: Live foraminiferal faunas from a $2800 \mathrm{~m}$ deep lower canyon station from the Bay of Biscay: Faunal response to focusing of refractory organic matter, Deep-Sea Res. I, 52, 1189-1227, 2005.

Gage, J. D. and Tyler, P. A.: Deep-Sea Biology: A Natural History of Organisms at the Deep-Sea Floor, Cambridge University Press, Cambridge, 504 pp., 1991.

Geslin, E., Heinz, P., Hemleben, C., and Jorissen, F. J.: Migratory response of deep-sea benthic foraminifera to variable oxygen conditions: laboratory investigations, Marine Micropaleontol., 53, 227-243, 2004.

Gooday, A. J.: Benthic foraminifera (Protista) as tools in deep-water palaeoceanography: a review of environmental influences on faunal characteristics, Adv. Mar. Biol., 46, 1-90, 2003.

Gooday, A. J., Bernhard, J. M., Levin, L. A., and Suhr, S. B.: Foraminifera in the Arabian Sea oxygen minimum zone and other oxygen deficient settings: taxonomic composition, diversity, and relation to metazoan faunas, Deep-Sea Res. II, 47, 2554, 2000.

Gooday, A. J., Hughes, J. A., and Levin, L. A.: The foraminiferan macrofauna from three North Carolina (USA) slope sites with contrasting carbon flux: a comparison with the metazoan macrofauna, Deep-Sea Res I, 48, 1709-1739, 2001.

Gooday, A. J., Levin, L. A., Aranda da Silva, A., Bett, B., Cowie, G., Dissard, D., Gage, J., Hughes D., Jeffreys R., Larkin K., Murty, S.J., Shumaker, S, Whitcraft, C., and Woulds, C.: Faunal responses to oxygen gradients on the Pakistan margin: a comparison of foraminifera, macrofauna and megafauna, Deep-Sea Res. II, 56, 488-502, 2009.

Grantham, B. A., Chan, F., Nielsen, K. J., Fox, D. S., Barth, J. A., Huyer, A., Lubchenco, J., and Menge, B. A.: Upwelling-driven nearshore hypoxia signals ecosystem and oceanographic changes in the northeast Pacific, Nature, 429, 749-754, 2004.

Gray, J. S., Wu, R. S. S. and Or, Y. Y.: Effects of hypoxia and organic enrichment on the coastal marine environment, Mar. Ecol. Prog. Ser., 238, 249-279, 2002.

Green, M. A., Aller, J. C., and Aller, J. Y.: Carbonate dissolution and temporal abundances of Foraminifera in Long Island Sound sediments, Limnol. Oceanol., 38, 331-345, 1993.

Guillard, R. R. L., Murphy, L. S., Foss, P., and Liaaen-Jensen, S.: Synechococcus spp. as likely zeaxanthin-dominant ultraphytoplankton in the North Atlantic, Limnol Oceanogr., 30, 412-414, 1985.

Guiot, J. and de Vernal, A.: Transfer functions: methods for quantitative paleoceanography based on microfossils, in: Proxies in Late Cenozoic Paleoceanography, edited by: Hillaire-Marcel, C. and de Vernal, A., Elsevier, Amsterdam, Boston, Heidelberg, London, New York, Oxford, Paris, San Diego, San Francisco, Singapore, Sydney, Tokyo, 523-563, 2007.

Hagy, J. D., Boynton, W. R., Keefe, C. W., and Wood, K. V.: Hypoxia in Chesapeake Bay, 1950-2001: long-term change in relation to nutrient loading and river flow, Estuaries, 27, 634-658, 2004.

Hall, R. I. and Smol, J. P.: Diatoms as indicators of lake eutrophication, in: The Diatoms: Applications for the Environmental and Earth Sciences, edited by: Stoermer, E. F. and Smol, J. P., Cambridge University Press, Cambridge, UK, 128-168, 1999.

Harper, D. E., McKinney, L. D., Nance, J. M., and Salzer, R. R.: Recovery of two benthic assemblages following an acute hypoxic event on the Texas continental shelf, northwestern Gulf of Mexico, in: Modern and Ancient Continental Shelf Anoxia, edited by: Tyson, R. V. and Pearson, T. H., Geological Society Special Publication, 58, 49-64, 1991.

Haslett, S. K.: Quaternary Environmental Micropalaeontology. London: Arnold, 340 pp., 2002.

Helly, J. J. and Levin, L. A.: Global distribution of naturally occurring marine hypoxia on continental margins, Deep-Sea Res. I, 51, 1159-1168, 2004.

Hedges, J. I. and Keil, R. G.: Sedimentary organic-matter preservation - an assessment and speculative synthesis, Mar. Chem., 49, 81-115, 2005.

Hendy, I. L. and Pedersen, T. F.: Oxygen minimum zone expansion in the eastern tropical North Pacific during deglaciation, Geophys. Res. Lett., 33, L20602, doi:10.1029/2006GL025975, 2006.

Herguera, J. C. and Berger, W. H.: Paleoproductivity from benthic foraminifera abundance: glacial to post-glacial change in westequatorial Pacific, Geology, 19, 1173-1176, 1991.

Hillaire-Marcel, C. and De Vernal, A. (Eds.): Proxies in Late Cenozoic Paleoceanography, Developments in Marine Geology, 
Vol. 1, Elsevier: Amsterdam, Boston, Heidelberg, London, New York, Oxford, Paris, San Diego, San Francisco, Singapore, Sydney, Tokyo, 843 pp., 2007.

Hughes, D. J., Lamont, P. A., Levin, L. A. Packer, M. and Gage, J. D.: Macrofaunal community structure and bioturbation across the Pakistan margin Oxygen Minimum Zone, north-east Arabian Sea, Deep-sea Res. II, 56, 334-448, 2009.

Huppert, A. and Aolow, A. R.: A method for reconstructing climate from fossil beetle assemblages, Philos. T. Roy Soc. A., 271, 1125-1128, 2004.

Husum, K. and Alve, E.: Development of dysoxia in Norwegian fjords during the 20th century: natural or anthropogenic causes, Geophys. Res. Abstracts, 8, 03976, 2006.

Ikeya, N.: Ostracoda in sediment cores from Yokohama Port, in: Changes in marine organisms and environments at Yokohama Port: research on fossils in sediment core samples, Yokohama Environmental Research Institute, Report no 116, 27-33, 1995.

Itoh, N., Tani, Y., Nagatani, T., and Soma, M.: Phototrophic activity and redox condition in Lake Hamana, Japan, indicated by sedimentary photosynthetic pigments and molybdenum over the last 250 years, J. Paleolimnol., 29, 403-422, 2003.

Jackson, J. B. C., Kirby, M. X., Berger, W. H., Bjorndal, K. A., Botsford, L. W., Bourque, B. J., Bradbury, R. H., Cooke, R., Erlandson, J., Estes, J. A., Hughes, T. P., Kidwell, S., Lange, C. B., Lenihan, H. S., Pandolfi, J. M., Peterson, C. H., Steneck, R. S., Tegner, M. J., and Warner, R. R.: Historical overfishing and the recent collapse of coastal ecosystems, Science, 293, 629637, 2001

Jackson, S. T.: Looking forward from the past: history, ecology and conservation, Front. Ecol. Environ., 9, p 455, 2007.

Jahn, A., Gamenick, I., and Theede, H.: Physiological adaptations of Cyprideis torosa (Crustacea, Ostracoda) to hydrogen sulphide, Mar. Ecol. Prog. Ser., 142, 215-223, 1996.

Jannink, N. T.: Seasonality, biodiversity and microhabitats in benthic foraminiferal communities, Geologica Ultraiectina, 203, 1190, 2001.

Jonsson, P., Carmen, R., and Wulff, F.: Laminated sediments in the Baltic - a tool for evaluating nutrient mass balance, Ambio, 19, 152-158, 1990.

Jorissen, F. J.: The distribution of benthic foraminifera in the Adriatic Sea, Mar. Micropaleontol., 12, 21-48, 1987.

Jorissen, F.: Benthic foraminiferal microhabitats below the sediment-water interface, in: Modern Foraminifera, edited by: Sen Gupta, B. K., Kluwer Academic Publishers, Dordrecht, Boston, London, 161-179, 1999a.

Jorissen, F.: Benthic foraminiferal sucessions across Late Quaternary Mediterranean sapropels, Mar. Geol., 153, 91-101, 1999b.

Jorissen, F., Fontanier, C., and Thomas, E.: Paleoceanographical proxies based on deep-sea benthic foraminiferal assemblage characteristics, in: Proxies in Late Cenozoic Paleoceanography, edited by: Hillaire-Marcel, C. and de Vernal, A., Elsevier, Amsterdam, Boston, Heidelberg, London, New York, Oxford, Paris, San Diego, San Francisco, Singapore, Sydney, Tokyo, 263-325, 2007.

Jorissen, F. J., Wittling I., Peypouquet J. P., Rabouille, C., and Relexans, J. C.: Live benthic foraminiferal faunas off Cap Blanc, NW Africa: community structure and microhabitats. Deep-Sea Res. I, 45, 2157-2188, 1998.

Justić, D.: Hypoxic conditions in the northern Adriatic Sea: historical development and ecological significance, edited by: Tyson, R. V. and Pearson, T. H., Modern and Continental Shelf Anoxia, Geological Society of London Special Publication, 95106, 1991.

Justić, D., Legović, T., and Rottini-Sandri, L.: Trends in oxygen content 1911-1984 and occurrence of benthic mortality in the northern Adriatic Sea, Estuar. Coast. Shelf Sci., 25, 435-445, 1987.

Justić, D., Rabalais, N. N., and Turner, R. E.: Modeling the impacts of decadal changes in riverine nutrient fluxes on coastal eutrophication near the Mississippi River Delta, Ecol. Model., 152, 33-46, 2002.

Justić, D., Rabalais, N. N., and Turner, R. E.: Coupling between climate variability and marine coastal eutrophication: historical evidence and future outlook, J. Sea Res., 54, 25-35, 2005.

Kaiho, K.: Benthic foraminiferal dissolved-oxygen index and dissolved-oxygen levels in the modern ocean, Geology, 22, 719722, 1994.

Kaiho, K.: Effect of organic carbon flux and dissolved oxygen on the benthic foraminiferal oxygen index (BFOI), Mar. Micropaleontol., 37, 67-76, 1999.

Karlsen, A. W., Cronin, T. M., Ishman, S. E., Willard, D. A., Kerhin, R., Holmes, C. W., and Marot, M.: Historical trends in Chesapeake Bay dissolved oxygen based on benthic Foraminifera from sediment cores, Estuaries, 23, 488-508, 2000.

Kauppila, P., Weckström, K., Vaalgamaa, S., Korhola, A., Pitkänen, H., Reuss, N., and Drew, S.: Tracing pollution and recovery using sediments in an urban estuary, northern Baltic Sea: are we far from ecological reference conditions? Mar. Ecol.-Prog. Ser., 290, 35-53, 2005.

Kemp, W. M., Boynton, W. R., Adolf, J. E., Boesch, D. F., Boicourt W. C., Brush G., Koopmans, M. P., Köster, J., van Kaam-Peters, H. M. E., Kenig, F., Schouten, S., Hartgers, W. A., de Leeuw, J. W., and Sinninghe Damsté, J. S. S: Diagenetic and catagenic products of isorenieratene: molecular indicators of photic zone anoxia, Geochim. Cosmochim. Ac., 60, 4467-4496, 1996.

Koho, K. A., Langezaal, A. M., Van Lith, Y. A., Duijnstee, I. A. P. and Van der Zwaan, G. J.: The influence of a simulated diatom bloom on deep-sea benthic foraminifera and the activity of bacteria: a mesocosm study, Deep-Sea Res. I, 55, 696-719, 2008.

Koopmans, M. P., Köster, J., van Kaam-Peters, H. M. E., Kenig, F., Schouten, S., Hartgers, W. A., de Leeuw, J. W., and Sinninghe Damsté, J. S. S: Diagenetic and catagenetic products of isorenieratene: molecular indicators of photic zone anoxia, 60, 44674496, 1996.

Kurian, S., Agnihotri, R., Borole, D. V., Naqvi, S. W. A., Ferreira, A. M., and Vale, C.: Possible solar control on primary production along the Indian west coast on decadal to centennial time scales, J. Quaternary Sci., 24, 109-116, 2009.

Laine, A. O., Andersin, A.-B., Leiniö, S. and Zuur, A. F. Stratification-induced hypoxia as a structuring factor of macrozoobenthos in the open Gulf of Finland (Baltic Sea), J. Sea Res., 57, 65-77, 2007.

Larrasoaña, J. C., Roberts, A. P., Musgrave, R. J., Gracia, E., Piñero, E., Vega, M., and Martinez-Ruiz, F.: Diagenetic formation of greigite and pyrrhotite in gas hydrate marine sedimentary systems, Earth Planet. Sc. Lett., 261, 350-366, doi:10.1016/j.epsl.2007.06.032, 2007.

Leipe, T., Dippner, J. W., Hille, S., Voss, M., Christiansen, C., and 
Bartholdy, J.: Environmental changes in the central Baltic Sea during the past 1000 years: inferences from sediment records, hydrography and climate, Oceanologia, 50, 23-41, 2008.

Levin, L. A.: Oxygen Minimum Zone Benthos: Adaptation and Community Response to Hypoxia, Oceanogr. Mar. Biol.: an annual review, according to the web of science, 41, 1-45, 2003.

Levin, L. A. and Gage, J. D.: Relationships between oxygen, organic matter and the diversity of bathyal macrofauna, Deep-Sea Res. II, 45, 129-163, 1998.

Levin, L. A., Gage, J. D., Martin, C., and Lamont, P. A.: Macrobenthic community structure within and beneath the oxygen minimum zone, NW Arabian Sea, Deep-Sea Res. II, 47, 189226, 2000.

Levin, L. A., Ekau, W., Gooday, A. J., Jorrisen, F., Middelburg, J., Naqvi, W., Neira, C., Rabalais, N. and Zhang, J.: Effects of Natural and Human-Induced Hypoxia on Coastal Benthos, Biogeosciences, 2009.

Levin, L. A., Whitcraft, C. R., Mendoza, G. F., Gonzalez, J. P., and Cowie, G. L.: Oxygen and organic matter thresholds for benthic faunal activity on the Pakistan Margin oxygen minimum zone (700-1100 m), Deep-Sea Res. II, 56, 449-471, 2009.

Li, D. and Daler, D.: Ocean pollution from land-based sources: East China Sea, China, Ambio, 33, 107-113, 2004.

Lipps, J. H. (Ed.): Fossil prokaryotes and protists, Blackwell Scientific Publications Oxford, 342 pp, 1993.

Liu J., Zhu, R. X., Roberts, A. P., Li, S. Q., and Chang, J.H.: High-resolution analysis of early diagenetic effects on magnetic minerals in post-middle-Holocene continental shelf sediments from the Korea Strait. J. Geophys. Res., 109, B03103, doi:10.1029/2003JB002813, 2004.

Liu, S. M., Ye, X. W., Zhang, J., and Zhao, Y. F.: Problems with biogenic silica measurements in marginal seas, Mar. Geol., 192, 383-392, 2002.

Loubere, P.: Benthic foraminiferal assemblage formation, organic carbon flux and oxygen concentrations on the outer continental shelf and slope, J. Foram. Res., 27, 93-100, 1997.

Loubere, P., Gary, A., and Lagoe, M.: Benthic foraminiferal microhabitats and the generation of a fossil assemblage: theory and preliminary data, Mar. Micropaleontol., 20, 165-181, 1993.

Martin, R.E. (Ed.): Environmental Micropaleontology, Volume 15 of Topics in Geobiology, Kluwer Academic/Plenum Publishing, New York, USA, 481 pp, 2000.

Martinez, P., Bertrand, P., Shimmield, G. B., Cochrane, K., Jorissen, F. J., Foster, J., and Dignan, M.: Upwelling intensity and ocean productivity changes off Cape Blanc (northwestern Africa) during the last 70000 years: geochemical and micropalaeontological evidence, Mar. Geol., 158, 57-74, 1999.

Martins, V., Dubert, J., Jouanneau, J.-M., Weber, O., Ferreira da Silva, E., Patinha, C., Dias, J. M. A., and Rocha, F.: A multiproxy approach of the Holocene evolution of shelf-slope circulation on the NW Iberian continental shelf, Mar. Geol., 239, 1-18, 2007.

Matsuoka, K.: Eutrophication process recorded in dinoflagellate cyst assemblages: a case of Yokohama Port, Tokyo Bay, Sci. Total Environ., 231, 17-35, 1999.

McGann, M., Alexander, C. R., and Bay, S. M.: Response of benthic foraminifers to sewage discharge and remediation in Santa Monica Bay, California, Mar. Environ. Res., 56, 299-342, 2003.

McClelland, J. W. M. and Valiela, I.: Linking nitrogen in estuarine producers to land-derived sources, Limnol. Oceanogr., 43, 577-
$585,1998$.

McMinn, A.: Comparison of diatom preservation between oxic and anoxic basins in Ellis Fjord, Antarctica. Diatom Res., 10, 145151, 1995.

Menzel, D., Hopmans, E. C., de Bergen, P. F., de Leeuw, J. W., and Sinninghe Damsté, J. S. S: Development of photoic zone euxinia in the eastern Mediterranean basin during deposition of Pliocene sapropels, Mar. Geol., 189, 215-226, 2002.

Middelburg, J. J. and Herman, P. M.: Organic matter processing in tidal estuaries, Mar. Chem., 106, 127-147, 2007.

Middelburg, J. J., De Lange, G. J., Van der Weijden, C. H., and Sofiyiah, S.: Sediment chemistry of Kau Bay, Halmahera (eastern Indonesia), J. Sea Res., 24, 607-613, 1989.

Middelburg, J. J.: Organic carbon, sulphur, and iron in recent semieuxinic sediments of Kau Bay, Indonesia, Geochim. Cosmochim. Ac., 55, 815-828, 1991.

Middelburg, J. J., Calvert S. E., and Karlin R. E.: Organic-rich transitional facies in silled basins: response to sea-level changes, $\mathrm{Ge}-$ ology, 19, 679-682, 1991

Middelburg, J. J., Baas, M., ten Haven, H. L., and de Leeuw, J. W.: Organic geochemical characteristics of sediments from Kau Bay, Org. Geochem., 413-417, 1994.

Mojtahid, M., Jorissen, F. J., and Pearson, T. H.: Comparison of benthic foraminiferal and macrofaunal responses to organic pollution in the Firth of Clyde (Scotland), Mar. Pollut. Bull., 56, 42-76, 2008.

Modig, H. and Ólafsson, E.: Responses of Baltic invertebrates to hypoxic events, J. Exp. Mar. Biol. Ecol., 229, 133-148, 1998.

Moodley, L., van der Zwaan, G. J., Herman, P. M. J., Kempers, L., and van Breugel, P.: Differential response of benthic meiofauna to anoxia with special reference to Foraminifera (Protista: Sarcodina), Mar. Ecol. Prog. Ser., 158, 151-163, 1997.

Murray, J. W.: Comparative studies of living and dead benthic foraminiferal distributions, in: Foraminifera Vol. 2, edited by: Hedley, R. H. and Adams, C. G., Academic Press, London, New York, San Francisco, 45-109, 1976.

Murray, J. W.: Ecology and Applications of Benthic Foraminifera, Cambridge University Press, Cambridge, New York, Melbourne, Madrid, Cape Town, Singapore, São Paulo, 426 pp, 2006.

Murray, J. W.: The niche of benthic foraminifera, critical thresholds and proxies, Mar. Micropaleontol., 41, 1-7.

Murray, J. W. and Alve, E.: Benthic foraminifera as indicators of environmental change: marginal-marine, shelf and upper-slope environments, in: Quaternary Environmental Micropalaeontology, edited by: Haslett, S. K., Arnold, London, UK, 59-90, 2002.

Naqvi, S. W. A., Jayakumar, D. A., Narvekar, P. V., Naik, H., Sarma, V. V. S. S., D’Souza, W., Joseph, S., and George, M. D.: Increased marine production of $\mathrm{N}_{2} \mathrm{O}$ due to intensifying anoxia on the Indian continental shelf, Nature, 408, 346-349, 2000.

Naqvi, S. W. A, Naik, H., Jayakumar, D. A., Shailaja, M. S., and Narvekar, P. V.: Seasonal oxygen deficiency over the western continental shelf of India, in: Past and Present Water Column Anoxia, NATO Science Series, edited by: Neretin, L. , IV. Earth and Environmental Sciences - Vol. 64, Springer, 195-224, 2006a.

Naqvi, S. W. A., Naik, H., Pratihary, A., D’Souza, W., Narvekar, P. V., Jayakumar, D. A., Devol, A. H., Yoshinari, T., and Saino, T.: Coastal versus open-ocean denitrification in the Arabian Sea, Biogeosciences, 3, 621-633, 2006a, 
http://www.biogeosciences.net/3/621/2006/.

Nelsen, T. A., Blackwelder, P., Hood, T., McKee, B., Romer, N., Alvarez-Zarikian, C., and Metz, S.: Time-based correlation of biogenic, lithogenic and authigenic sediment components with anthropogenic inputs in the Gulf of Mexico NECOP study area, Estuaries, 17, 873-885, 1994.

Nikulina, A., Polovodova, I. and Schönfeld, J.: Foraminiferal response to environmental changes in Kiel Fjord, SW Baltic Sea, eEarth, 3, 37-49, 2008.

Nilsson, H. C. and Rosenberg, R.: Succession in marine benthic habitats and fauna in response to oxygen deficiency: analysed by sediment profile-imaging and by grab samples, Mar. Ecol.-Prog. Ser., 197, 139-149, 2000

Niggemann, J. and Schubert, C. J.: Fatty acid biogeochemistry of sediments from the Chilean coastal upwelling region: Sources and diagenetic changes, Org. Geochem., 37, 626-647, 2006.

Nishumira, M. and Koyama, T.: The occurrence of stanols in various living organisms and the behaviour of sterols in contemporary sediments, Geochim. Cosmochim. Ac., 41, 379-385, 1977.

Nixon, S. W.: Prehistoric nutrient inputs and productivity in Narragansett Bay, Estuaries, 20, 253-261, 1997.

Nomaki, H., Heinz, P., Hemleben, C., and Kitazato, H.: Behavior and response of deep-sea benthic foraminifera to freshly supplied organic matter: a laboratory feeding experiment in microcosm environments, J. Foram. Res., 35, 103-113, 2005.

Nordberg, K., Gustafsson, M., and Kranz, A. L.: Decreasing oxygen concentrations in the Gullmar Fjord, Sweden, as confirmed by benthic Foraminifera, and possible associations with NAO, J. Marine Syst., 23, 303-316, 2000.

Orsini, G., Capotondi, L., Colantoni, P., Galeotti, S., and Mencucci, D.: Benthic Foraminifera as indicators of environmental changes in the central Adriatic Sea, Geophys. Res. Abstracts, 8, 08098, 2006.

Orth, R. J. and Moore, K. A.: Chesapeake Bay: An unprecedented decline in submerged aquatic vegetation, Science, 222, 51-53, 1983.

Osterman, L. E.: Benthic foraminifers from the continental shelf and slope of the Gulf of Mexico: An indicator of shelf hypoxia, Estuar. Coast. Shelf Sci., 58, 17-35, 2003.

Osterman, L. E., Poore, R. Z., Swarzenski, P. W., and Turner, R. E.: Reconstructing a 180-yr record of natural and anthropogenic induced low-oxygen conditions from Louisiana continental shelf sediments, Geology, 33, 329-333, 2005.

Osterman, L. E., Poore, R. Z., and Swarzenski, P. W.: The last 1000 years of natural and anthropogenic low-oxygen bottom water on the Lousinana shelf, Gulf of Mexico, Mar. Micropaleontol., 66, 291-303, 2008.

Passier, H. F., Middelburg, J. J., van Os, B. J. H., and de Lange, G. J.: Diagenetic pyritisation under Eastern Mediterranean sapropels caused by downward sulphide diffusion, Geochim. Cosmochim. Ac., 60, 751-763, 1996.

Passier, H. F., Middelburg, J. J., de Lange, G. J., and Bottcher, M: Pyrite contents, microtextures and sulphur isotopes in the youngest eastern Mediterranean sapropel, Geology, 25, 519-522, 1997.

Parsons, M. L., Dortch, Q., and Turner, R. E.: Sedimentological evidence of an increase in Pseudo-nitzschia (Bacillariophyceae) abundance in response to coastal eutrophication, Limnol. Oceanogr., 47, 551-558, 2002.
Parsons, M. L., Dortch, Q., Turner, R. E., and Rabalais, N. N.: Salinity history of coastal marshes reconstructed from diatom remains, Estuaries, 22, 961-972, 1999

Parsons, M. L., Dortch, Q., Turner, R. E., and Rabalais, N. N.: Reconstructing the development of eutrophication in Louisiana salt marshes, Limnol. Oceanogr., 51, 534-544, 2006.

Passier, H. F., Bosch, H.-J., Nijenhuis, I. A., Lourens, L. J., Böttcher, M. E., Leenders, A., Sinninghe Damsté, J. S., de Lange, G. J., and de Leeuw, J. W.: Sulphidic Mediterranean surface waters during Pliocene sapropel formation, Nature, 397, 146-149, 1999.

Pawlowski, J., Bowser, S. S., and Gooday, A. J.: A note on the genetic similarity between shallow- and deep-water Epistominella vitrea (Foraminifera) in the Antarctic, Deep-Sea Res. II, 54, 1720-1726, 2007.

Persson, J. and Jonsson, P.: Historical development of laminated sediments - an approach to detect soft sediment ecosystem changes in the Baltic Sea, Mar. Pollut. Bull., 40, 122-124, 2000.

Phleger, F. B.: Benthic Foraminifera as indicators of organic production in marginal marine areas, in: 1st International Symposium on Benthic Foraminifera of Continental Margins, Part A: Ecology and Biology, Maritime Sediments Special Publication, 1, 107-117, 1976.

Phleger, F. B. and Soutar, A.: Production of benthic foraminifera in three east Pacific oxygen minima, Micropaleontol., 19, 110-115, 1973.

Pike, J., Bernhard, J. M., Moreton, S. G., and Butler, I. B.: Microirrigation of marine sediments in dysoxic environments: implications for early sediment fabric formation and diagenetic processes, Geology, 29, 923-926, 2001.

Pinturier-Geiss, L., Méjanelle, L., Dale, B., and Karlsen, D. A.: Lipids as indicators of eutrophication in marine coastal sediments, J. Microbiol. Meth., 48, 239-257, 2002.

Platon, E. and Sen Gupta, B. K.: Foraminiferal communities of oxygen-stressed environments on the Louisiana continental shelf, in: Coastal Hypoxia: Consequences for Living Resources and Ecosystems, edited by: Rabalais, N. N. and Turner, R. E., Coastal and Estuarine Studies 58, American Geophysical Union, Washington, DC, 147-163, 2001.

Platon, E., Sen Gupta, B. K., Rabalais, N. N., and Turner, R. E.: Effect of seasonal hypoxia on the benthic foraminiferal community of the Louisiana inner continental shelf: the 20th century record, Mar. Micropaleont., 54, 263-283, 2005.

Pospelova, V., Chmura, G. L., Boothman, W. S., and Latimer, J. S.: Dinoflagellate cyst records and human disturbance in two neighboring estuaries, New Bedford Harbor and Apponagansett, Bay, Massachusetts (USA), Sci. Total Environ., 298, 81-102, 2002.

Pucci, F., Geslin, E., Barras, C., Morigi, C., Sabbatini, A., Negri, A. and Jorissen, F. J. : Survival of benthic foraminifera under hypoxic conditions: Results of an experimental study using the Cell Tracker Green method. Mar. Poll. Bull., in press, 2009.

Puškarić, S., Berger, G. W., and Jorissen, F. J.: Sucessive appearance of subfossil phytoplankton species of the northern Adriatic Sea and its relation to increased eutrophication pressure, Estuar. Coast. Shelf S., 31, 177-187, 1990.

Rabalais, N. N.: Hipoxia en el Golfo de México, in: Diagnóstico Ambiental del Golfo de México Vol. II, edited by: Caso, M., Pisanty, I. and Excurra, E., Instituto Nacional de Ecología, Mexico, DF, 478-489, 2004. 
Rabalais, N. N. and Gilbert, D.: Distribution and consequences of hypoxia, in: Watersheds, bays, and bounded seas: The science and management of semi-enclosed marine systems, edited by: Urban, E. R. J., Sundby, B., Malanotte-Rizzoli, P., and Mellilo, J., vol. 70 of Scientific Committee on Problems of the Environment (SCOPE) Series, chap. 11, pp. 209-225, Island Press, Washington, DC, 2009.

Rabalais N. N. and Turner, R. E.: Hypoxia in the northern Gulf of Mexico: description, causes and change, in: Coastal hypoxia: consequences for living resources an decosystems, edited by: Rabalais, N. N. and Turner, R. E., Coast. Estuar. Stud., 58, American Geophysical Union, Washington DC, USA, 1-36, 2001.

Rabalais, N. N., Smith, L. E., Harper, D. E., and Justic, D.: Effects of seasonal hypoxia on continental shelf benthos, in: Coastal hypoxia: consequences for living resources an decosystems, edited by: Rabalais, N. N., and Turner, R. E., Coast. Estuar. Stud., 58, American Geophysical Union, Washington DC, USA, 211-240, 2001..

Rabalais, N. N., Turner, R. E., and Scavia, D.: Beyond science into policy: Gulf of Mexico hypoxia and the Mississippi River, BioScience, 52, 129-142, 2002.

Rabalais, N. N., Turner, R. E., Sen Gupta, B. K., Platon, E., and Parsons, M. L.: Sediments tell the history of eutrophication and hypoxia in the northern Gulf of Mexico, in: Nutrient Enrichment of Estuarine and Coastal Marine Environments, Ecol. Appl., 17, Supplement, S129-S143, 2007.

Rabalais, N. N. Turner, R. E., Justić, D., Dortch, Q., Wiseman Jr., W. J., and Sen Gupta, B. K.: Nutrient changes in the Mississippi River and system responses on the adjacent continental shelf, Estuaries, 19, 386-407, 1996.

Rabalais, N. N., Atilla, N., Normandeau, C., and Turner, R. E.: Ecosystem history of the Mississippi River-influenced continental shelf revealed through preserved phytoplankton pigments, Mar. Pollut. Bull., 49, 537-547, 2004.

Radi, T. and de Vernal, A.: Dinocysts as proxy of primary productivity in mid-high latitudes of the Northern Hemisphere, Marine Micropaleonotol., 68, 84-114, 2008.

Radi, T., Pospelova, V., de Vernal, A., and Barrie, J. V.: Dinoflagellate cysts as indicators of water quality and productivity in British Columbia estuarine environments, Marine Micropaleontol., 62, 269-297, 2007.

Raiswell, R., Buckley, F., Berner, R. A., and Anderson, T. F.: Degree of pyritization of iron as a paleoenvironmental indicator of bottom water oxygenation, J. Sediment. Petrol., 58, 812-819, 1988.

Rathburn, A. E. and Corliss, B. H.: The ecology of living (stained) deep-sea benthic foraminifera from the Sulu Sea, Paleoceanography, 9, 87-150, 1994.

Reuss, N., Conley, D. J., and Bianchi, T. S.: Preservation conditions and the use of sediment pigments as a tool for recent ecological reconstruction in four Northern European estuaries, Mar. Chem., 95, 283-302, 2005.

Rhoads, D. C., Mulsow, S. G., Gutschick, R., Baldwin, C. T., and Stolz, J. F.: The dysaerobic zone revisited: a magnetic facies?, in: Modern and Ancient Contiental Shelf Anoxia, edited by: Tyson, R. V. and Pearson, T. H., Geological Society, London, Special Publication, 58, 187-199, 1991.

Rhoads, D. C. and Morse, J. W.: Evolutionary and ecological significance of oxygen-deficient marine basins, Lethaia, 4, 413-428,
1971.

Risgaard-Petersen, N., Langezaal, A. M., Ingvardsen, I., Schmid, M. C., Jetten, M. S. M., Op den Camp, H. J. M., Derksen, J. W. M., Piña-Ochoa, E., Eriksson, S. P., Nielsen, L. P., Revsbech, N. P., Cedhagen, T., and van der Zwaan, G. J.: Evidence for complete denitrification in a benthic foraminifer, Nature, 443, 93-96, 2006.

Robinson S. G. and Sahota J. T. S.: Rock-magnetic characterization of early, redoxomorphic diagenesis in turbiditic sedments from the Madeira Abyssal Plain, Sedimentology, 47, 367-394, 2000.

Roberts, A. P., and Weaver, R.: Multiple mechanisms of remagnetization involving sedimentary greigite $\left(\mathrm{Fe}_{3} \mathrm{~S}_{4}\right)$, Earth Planet. Sc. Lett., 231, 263-277, 2005.

Rosenberg, R.: Marine benthic faunal successional stages and related sedimentary activity, Scientia Marina, 65 (supplement 2), 107-119, 2001.

Round, F. E., Crawford, R. M., and Mann, D. G.: The Diatoms: Biology and Morphology of the Genera, Cambridge University Press, Cambridge, UK, 747 pp., 1990.

Ruiz, F., Abad, M., Bodergat, A. M., Carbonel, P., RodriguezLázaro, J., and Yasuhara, M.: Marine and brackish-water ostracods as sentinels of anthropogenic impacts, Earth Sci. Rev., 72, 89-111, 2005.

Saenger, C., Cronin, T., Thunnel, R., and Vann, C.: Modeling river discharge and precipiation from estuarine salinity in the northern Chesapeake Bay: application to Holocene paleoclimate, Holocene, 16, 1-11, 2006.

Sangiorgi, S., and Donders, T.H.: Reconstructing 150 years of eutrophication in the north-west Adriatic Sea (Italy) using dinoflagellate cysts, pollen and spores, Estuar., Coast. Shelf Sci., 60, 6979, 2004.

Sato, H.: Diatom assemblages in core samples from Yokohama Port, in: Changes in marine organisms and environments at Yokohama Port: research on fossils in sediment core samples, Yokohama Environmental Research Institute, Report no. 116, 63-76, 1995.

Savrda, C. E. and Bottjer, D. J.: The exaerobic zone: a new oxygendeficient marine biofacies, Nature, 327, 54-56, 1987.

Savrda, C. E. and Bottjer, D. J.: Oxygen-related biofacies in marine strata: an overview and update, in: Modern and ancient continental shelf anoxia, edited by: Tyson, R. V. and Pearson, T. H., Geological Society Special Publication, 58, 201-219, 1991.

Savrda, C. E., Bottjer, D. J., and Gorsline, D. S.: Development of a comprehensive oxygen-deficient marine biofacies model; evidence from Santa Monica, San Pedro, and Santa Barbara basins, California continental borderland, AAPG Bull., 58, 1179-1192, 1984.

Schaffner, L. C., Jonsson P., Diaz, R. J., Rosenberg, R., and Gapcynski, P.: Benthic communities and bioturbation history of estuarine and coastal systems: effects of hypoxia and anoxia, Sci. Total Environ. (supplement), 1001-1017, 1992.

Schulte, S., Mangelsdorf, K., and Rullkotter, J.: Organic matter preservation on the Pakistan continental margin as revealed by biomarker geochemistry, Org. Geochem., 31, 1005-1022, 2000.

Schmiedl, G., Mitschele, A., Beck, S., Emeis, K. C., Hemleben, C., Schulz, H., Sperling, M., and Weldeab, S.: Benthic foraminiferal record of ecosystem variability in the eastern Mediterranean Sea during times of sapropel $\mathrm{S}_{5}$ and $\mathrm{S}_{6}$ deposition, Palaeogeogr. Palaeocl., 190, 139-164, 2003. 
Schweizer, M., Pawlowski, J., Kouwenhoven, T. J., Guiard, J., and van der Zwaan, B.: Molecular phylogeny of Rotaliida (Foraminifera) based on complete small subunit rDNA sequences, Mar. Micropaleontol., 66, 233-246, 2008

Sen Gupta, B. K. and Platon, E.: Tracking past sedimentary records of oxygen depletion in coastal waters: use of the AmmoniaElphidium foraminiferal index, J. Coast. Res., Special Issue, 39, 1351-1355, 2006.

Sen Gupta, B. K., Lee, R. F., and May, M. S.: Upwelling and an unusual assemblage of benthic foraminifera on the northern Florida continental slope, J. Paleontol., 55, 853-857, 1981.

Sen Gupta, B. K. and Machain-Castillo, M. L.: Benthic foraminifera in oxygen-poor habitats, Mar. Micropaleontol., 20, 183-201, 1993.

Sen Gupta, B. K., Turner, R. E., and Rabalais, N. N.: Seasonal oxygen depletion in continental-shelf waters of Louisiana: Historical record of benthic foraminifers, Geology, 24, 227-230, 1996.

Shankle, A. M., Goericke, R., Franks, P. J. S., and Levin, L. A.: Chlorin distribution and degradation in sediments within and below the Arabian Sea oxygen minimum zone, Deep-Sea Res. I, 49, 953-969, 2002.

Sinninghe Damsté J. S. S., Wakeham, S. G., Kohnen, M. E. L., Hayes, J. M., and de Leeuw, J. W.: A 6000 year sedimentary molecular record of chemocline excursions in the Black Sea, Nature, 362, 827-829, 1993.

Sinninghe Damsté J. S. S., Rijpstra W. I. C., and Reichart G. J.: The influence of oxic degradation on the sedimentary biomarker record II. Evidence from Arabian Sea sediments, Geochim. Cosmochim. Ac., 66, 2737-2754, 2002.

Sinninghe Damsté, J. S. S., Kuypers, M. M. M., Schouten, S., Schulte, S., and Rullkotter, J.: The lycopane/ $\mathrm{C}_{31} n$-alkane ratio as a proxy to assess palaeoxicity during sediment deposition, Earth, Planet. Sc. Lett., 209, 215-226, 2003.

Smith, V.H.: Eutrophication of freshwater and coastal marine ecosystems: A global problem, Environ. Sci. Pollut. R., 10, 126139, 2003

Smittenberg, R.H., Baas, M., Green, M.J., Hopmans, E.C., Schouten, S., and Sinninghe Damsté, J.S.S.: Pre- ad postindustrial environmental changes as revealed by the biogeochemical sedimentary record of Drammensfjord, Norway, Mar. Geol., 214, 177-200, 2005.

Smittenberg, R. H., Pancost, R. D., Hopmans, E. C., Paetzel, M., and Sinninghe Damsté, J. S. S.: A 400-year record of environmental change in an euxenic fjord as revealed by the sedimentary biomarker record, Palaeogeogr. Palaeocl., 202, 331-351.

Soetaert, K., Middelburg J. J., Heip C., Meire P., Van Damme S., and Maris, T.: Long term change in dissolved inorganic nutrients in the heterotrophic Scheldt estuary (Belgium, the Netherlands), Limnol. Oceanogr., 51, 409-423, 2006.

Stoermer, E. F. and Smol, J. P.: The Diatoms: Applications for Environmental and Earth Sciences, Cambridge University Press, 482 pp, 1999

Stott, L. D., Berelson, W., Douglas, R., and Gorsline, D.: Increased dissolved oxygen in Pacific intermediate waters due to lower rates of carbon oxidation in sediments, Nature, 407, 367-370, 2000.

Struck, U., Emeis, K.-C., Voss, M., Christiansen, C., and Kunzendorf, H.: Records of southern and central Baltic Sea eutrophication in $\delta^{15} \mathrm{~N}$ of sedimentary organic matter, Mar. Geol., 164,
157-171, 2000.

Suess, H.E.: Radiocarbon concentration in modern wood, Science, 122, 415-417, 1955.

Swarzenski, P. W., Campbell, P. L., Osterman, L. E. and Poore, R. Z.: A 1000-year sediment record of recurring hypoxia off the Mississippi River: the potential role of terrestrially-derived organic matter inputs, Mar. Chem., 109, 130-142, 2008

Taylor, S. R.: The abundance of chemical elements in the continental crust - a new table, Geochim. Cosmochim. Ac., 28, 12731285, 1964.

Thibodeau, B., de Vernal, A., and Mucci, A.: Recent eutrophication and consequent hypoxia of the Lower St. Lawrence Estuary: Micropaleontological and geochemical evidence, Mar. Geol., 231, 37-50, 2006.

Thomas, E.: Multiproxy records of eutrophication in Long Island Sound, Geological Society of America 2006 Philadelphia Annual Meeting (22-25 October 2006), Paper N. 130-10, 2006.

Thomas, E., Abramson, I., Varekamp, J. C., and Buchholtz ten Brink, M. R.: Eutrophication of Long Island Sound as traced by benthic foraminifera, Sixth Biennual LIS Research Conference Proceedings, 87-91, 2004.

Thomas, E., Gapotchenko, T., Varekamp, J. C., Mecray, E. L., and Buchholtz ten Brink, M. R.: Benthic Foraminifera and environmental changes in Long Island Sound, J. Coast. Res., 16, 641645, 2000.

Thorsen, T. A., and Dale, B.: Dinoflagellate cysts as indicators of pollution and past climate in a Norwegian fjord, Holocene, 7 , 433-446, 1997.

Thunnell, R. C., Tappa, E., and Anderson, D. M.: Sediment fluxes and varve formation in Santa Barbara Basin, offshore California, Geology, 23, 1083-1086, 1995.

Toyoda, K. and Kitazato, H.: Paleoenvironmental changes in Yokohama Port since 1870 based on benthic foraminiferal fossils, in: Changes in marine organisms and environments at Yokohama Port: research on fossils in sediment core samples, Yokohama Environmental Research Institute, Report 116, 11-26, 1995.

Tribovillard, N., Algeo T. J., Lyons T., and Riboulleau A.: Trace metals as paleoredox and paleoproductivity proxies: An update, Chem. Geol., 232, 12-32, 2006.

Tsuchiya, M., Grimm, G. W., Heinz, P., Stögerer, K., Ertan, K. T., Collen, J., Brüchert, V., Hemleben, C., Hemleben, V., and Kitazato, H.: Ribosomal DNA shows extremely low genetic divergence in a world-wide distributed, but disjunct and highly adapted marine protozoan (Virgulinella fragilis, Foraminiferida), Marine Micropaleontol., 70, 8-19, 2009.

Tsujimoto, A., Nomura, R., Yasuhara, M., and Yoshikawa, S.: Benthic foraminiferal assemblages in Osaka Bay, southwestern Japan: faunal changes over the last 50 years, Paleontol. Res., 10, 141-161, 2006a.

Tsujimoto, A., Nomura, R., Yasuhara, M., Yamazaki, H., and Yoshikawa, S.: Impact of eutrophication on shallow marine benthic foraminifers over the last 150 years in Osaka Bay, Japan, Marine Micropaleontol., 60, 258-268, 2006b

Tsujimoto, A., Yasuhara, M., Nomura, R., Yamazaki, H., Sampai, Y., Hirose, K. and Yoshikawa, S.: Development of modern benthic ecosystems in eutrophic coastal oceans: the foraminiferal record over the last 200 years, Osaka Bay, Japan, Marine Micropaleontol., 69, 225-239, 2008.

Turner, R. E. and Rabalais, N. N.: Coastal eutrophication near the 
Mississippi river delta, Nature, 368, 619-621, 1994.

Turner, R. E. and Rabalais, N.N.: Changes in Mississippi River water quality this century and implications for coastal food webs, BioScience, 41, 140-147, 1991.

Turner, R. E. and Rabalais, N. N.: Linking landscape and water quality in the Mississippi River basin for 200 years, BioScience, 53, 563-572, 2003.

Turner, R. E., Milan, C. S., and Rabalais, N. N.: A retrospective analysis of trace metals, $\mathrm{C}, \mathrm{N}$ and diatom remnants in sediments from the Mississippi River delta shelf, Mar. Pollut. Bull., 49, 548-556, 2004.

Turner, R. E., Rabalais, N. N., Justić, D., and Dortch, Q.: Future aquatic nutrient limitations, Mar. Pollut. Bull., 46, 1032-1034, 2003a.

Turner, R. E., Rabalais, N. N., Justić, D., and Dortch, Q.: Global patterns of dissolved N, P and Si in large rivers, Biogeochemistry, 64, 297-317, $2003 \mathrm{~b}$.

Turner, R. E., Rabalais, N. N., Fry, B., Atilla, N., Milan, C. S., Lee, J. M., Normandeau, C., Oswald, T. A., Swenson, E. M., and Tomasko, D. A.: Paleo-indicators and water quality change in the Charlotte Harbor Estuary (Florida), Limnol. Oceanogr., 51, 518-533, 2006.

Tyson, R. V. and Pearson, T. H.: Modern and ancient continental shelf anoxia: an overview, in: Modern and ancient continental shelf anoxia, edited by: Tyson, R. V. and Pearson, T. H., Geological Society Special Publication, 58, 1-24, 1991.

Van Geen, A., Zheng, Y., Bernhard, J. M., Cannariato, K. G., Carriquiry, J., Dean, W. E., Eakins, B. W., Ortiz, J. D., and Pike, J.: On the preservation of laminated sediments along the western margin of North America, Paleoceanography, 18, 22-1 to 22-17, 2003

Van der Zwaan, G. J.: Variation in natural vs. anthropogenic eutrophication of shelf areas in front of major rivers, in: Environmental Micropaleontology, edited by: Martin, R. E., Vol. 15 of Topics in Geobiology, Kluwer Academic/Plenum Publishing, New York, USA, 385-404, 2000.

Van der Zwaan, G. J. and Jorissen., F. J.: Biofacial patterns in river induced shelf anoxia, in: Modern and Ancient Continental Shelf Anoxia, edited by: Tyson, R. V. and Pearson, T. H., Geological Society Special Publication, 58, 415-425, 1991.

Vásquez-Bedoya, L. F., Radi, T., Ruiz-Fernández, A. C., de Vernal, A., Machain-Castillo, M. L., Kielt, J. F. and Hillaire-Marcel, C.: organic-walled donoflagellate cysts and benthic foraminifera in coastal sediments of the last century from the Gulf of Tehuantepec, South Pacific coast of Mexico, Marine Micropaleontol., 68, 49-65, 2008.

Verburg, P.: The need to correct for the Suess effect in the application of $\delta^{13} \mathrm{C}$ in sediment of sutotrophic Lake Tanganyika, as a productivity proxy in the Anthropocene, J. Paleolimnol., 37, 591-602, 2007.

de Vernal, A., and Marret, F.: Organic-walled dinoflagellate cysts: tracers of sea-surface conditions, in: Proxies in Late Cenozoic Paleoceanography, edited by: Hillaire-Marcel, C. and de Vernal, A., Elsevier, Amsterdam, 371-408, 2007.

de Vernal, A., Rochon, A., and Radi, T.: Dinoflagellates, in: Encyclopedia of Quaternary Science Paleoceanography, edited by: Elias, S. A., Biological Proxies, 3, 652-1667, 2006

Versteegh, G. J. M. and Zonneveld, K. A. F.: Use of selective degradation to separate preservation from productivity, Geology, 30,
615-618, 2003.

Voss, M. and Struck, U.: Stable nitrogen and carbon isotopes as indicators of eutrophication of the Oder river (Baltic Sea), Mar. Chem., 59, 35-49, 1997.

Voss, M., Larsen, B., Leivuori, M., and Vallius, H.: Stable isotope signals of eutrophication in Baltic Sea sediments, J. Marine Syst., 25, 287-298, 2000.

Wada, E. and Hattori, A.: Nitrogen in the sea: forms, abundances, and rate processes, CRC Press, Boca Raton, 208 pp, 1991.

Warning, B. and Brumsack, H.-J.: Trace metal signatures of eastern Mediterranean sapropels, Palaeogeogr. Palaeocl., 158, 293-309, 2000.

Wei, H., He, Y., Li, Q., Liu, Z., and Wang, H.: Summer hypoxia adjacent to the Changjiang Estuary, J. Marine Syst., 67, 292303, 2007.

Whatley, R. C., Pyne, R. S., and Wilkinson, I. P.: Ostracoda and palaeo-oxygen levels, with particular reference to the Upper Cretaceous of East Anglia, Palaeogeogr. Palaeocl., 194, 355-386, 2003.

Wijsman, J. W. M., Middelburg, J. J., and Heip, C. H. R.: Reactive iron in Black Sea sediments, Mar. Geol., 172, 167-180, 2001a.

Wijsman J. W. M., Middelburg J. J., Herman P. M. J., Bottcher, M., and Heip, C. H. R.: Sulfur and iron speciation in surface sediments along the northwestern margin of the Black Sea, Mar. Chem., 74, 261-278, 2001 b.

Wilkins, R. T., Barnes, H. L., and Brantley, S. L.: The size distribution of framboidal pyrite in modern sediments: An indicator of redox conditions, Geochim. Cosmochim. Ac., 60, 3897-3912, 1996.

Willard, D. A. and Cronin, T. M.: Paleoecology and ecosystem restoration: case studies from Chesapeake Bay and the Florida Everglades, Front. Ecol. Environ., 5, 491-498, doi:10.1890/070015, 2007.

Willard, D. A., Cronin, T. M., and Verado, S.: Late-Holocene climate and ecosystem history from Chesapeake Bay sediment cores, USA, Holocene, 13, 201-214, 2003.

Woulds, C., Cowie, G. L., Levin, L. A., Andersson, H., Vandewiele, S., Lamont, P .A., Larkin, K. E., Gooday, A. J., and Schumacher S.: Oxygen as a control on the biological cycling of organic matter, Limnol. Oceanogr., 52, 1698-1709, 2007.

Wright, S.W., and Jeffrey, S. W.: Fucoxanthin pigment markers of marine phytoplankton analysed by HPLC and HPTLC, Mar. Ecol.-Prog. Ser., 38, 259-268, 1987.

Yadav, R. R. and Singh, J.: Tree-ring-based spring temperature patterns over the past four centuries in western Himalya, Quaternary Res., 57, 299-305, 2002.

Yasuhara, M. and Yamazaki, H.: The impact of 150 years of anthropogenic pollution on the shallow marine ostracode fauna, Osaka Bay, Japan, Mar. Micropaleontol., 55, 63-74, 2005.

Yasuhara, M., Yamazaki, H., Irizuki, T., and Yoshikawa, S.: Temporal changes in ostracod assemblages and anthropogenic pollution during the last 100 years, in sediment cores from Hiroshima Bay, Japan, Holocene, 13, 527-536, 2003.

Yasuhara, M., Yamazaki, H., Tsujimoto, A., and Horose, K.: The effect of long-term spatiotemporal variations in urbanizationinduced eutrophication on a benthic ecosystem, Osaka Bay, Japan, Limnol. Oceanogr., 52, 1633-1644, 2007.

Zheng, Y., Weinman, B., Cronin, T., Fleisher, M. Q., and Anderson, R. F.: A rapid procedure for the determination of thorium, 
uranium, cadmium and molybdenum in small sediment samples by inductively coupled plasma-mass spectrometry: application in Chesapeake Bay, Appl. Geochem., 18, 539-549, 2003.

Zillén, L., Conley, D. J., Andrén, T., Andrén, E., and Björck, S.: Past occurrences of hypoxia in the Baltic Sea and the role of climate variability, environmental change and human impact, Earth-Sci. Rev., 91, 77-92, 2008.

Zimmerman, A. R. and Canuel, E. A.: A geochemical record of eutrophication and anoxia in Chesapeake Bay sediments, Mar. Chem., 69, 117-137, 2000.

Zimmerman, A. R. and Canuel, E. A.: Bulk organic matter and lipid biomarker composition of Chesapeake Bay surficial sediments as indicators of environmental processes, Estuar. Coast. Shelf Sci., 53, 319-341, 2001.
Zimmerman, A. R. and Canuel, E. A.: Sediment geochemical records of eutrophication in the mesohaline Chesapeake Bay. Limnol. Oceanogr., 47, 1084-1093, 2002.

Zonneveld, K. A. F., Versteegh, G. J. M., and de Lange, G. J.: Preservation of organic-walled dinoflagellate cysts in different oxygen regimes: a 10000 year natural experiment, Mar. Micropaleontol., 29, 393-405, 1997. 